Andrews University

Digital Commons @ Andrews University

Professional Dissertations DMin

Graduate Research

1994

\title{
A Qualitative Study of Prayer as the Pastor's Work
}

Kenneth Lee Schander

Follow this and additional works at: https://digitalcommons.andrews.edu/dmin

\section{Recommended Citation}

Schander, Kenneth Lee, "A Qualitative Study of Prayer as the Pastor's Work" (1994). Professional Dissertations DMin. 656.

https:dx.doi.org/10.32597/dmin/656

https://digitalcommons.andrews.edu/dmin/656

This Project Report is brought to you for free and open access by the Graduate Research at Digital Commons @ Andrews University. It has been accepted for inclusion in Professional Dissertations DMin by an authorized administrator of Digital Commons @ Andrews University. For more information, please contact repository@andrews.edu. 


\section{ABSTRACT}

\section{A QUALITATIVE STUDY OF PRAYER}

AS THE PASTOR'S WORK

by

Kenneth Lee Schander

Adviser: Douglas R. Kilcher 


\title{
ABSTRACT OF GRADUATE STUDENT RESEARCH
}

\author{
Project Report
}

Andrews University

Seventh-day Adventist Theological Seminary

\author{
Title: A QUALITATIVE STUDY OF PRAYER AS THE PASTOR'S WORK \\ Name of researcher: Kenneth Lee Schander \\ Name and degree of faculty adviser: Douglas R. Kilcher, D.Min. \\ Date completed: June 1994
}

\section{Problem}

This study is an attempt to understand the pastor's perspective regarding prayer as a part of his/her work. The nature of the pastor's work has been debated throughout the history of the Christian church without consensus. This uncertainty regarding the role of the pastor is increasing. In the confusion over what constitutes the pastor's job, his/her call to be a person of prayer has been largely lost sight of. A critical need exists to understand prayer as a priority for pastors.

\section{Method}

The study is divided into two sections. The first section is an overview of the relevant biblical materials in which special attention is given to prayer as a function 
of the prototypes of modern ministry: the apostles and their successors, the elders. The second is a discussion of the major themes discovered in a series of personal indepth, open-ended interviews conducted with a purposive sample of five practicing clergy of various denominations regarding their understanding of prayer as part of their work. In both instances, the approach is a qualitative inquiry seeking to appreciate what pastors do in the settings in which they work.

\section{Results}

The pastors who, as "living human documents," participated in this study exhibit several significant characteristics. They wrestle with feelings of guilt about their prayer lives. They also struggle with the challenge to balance their role as persons of prayer with the pressures of everyday ministry. The pastors also express a desire to be held accountable for being persons of prayer.

\section{Conclusions}

If pastors are to give greater priority to prayer as a function of ministry in the modern church, there will need to be (1) a renewed understanding of the role prayer played in New Testament ministry, (2) more appreciation of the contradictions pastors live with in their work, and (3) increased support from their denominations and congregations for their work of prayer. 
Andrews University

Seventh-day Adventist Theological Seminary

A QUALITATIVE STUDY OF PRAYER

AS THE PASTOR'S WORK

\author{
A Project Report \\ Presented in Partial Fulfillment \\ of the Requirements for the Degree \\ Doctor of Ministry
}

by

Kenneth Lee Schander

June 1994 



\title{
A QUALITATIVE STUDY OF PRAYER
}

\section{AS THE PASTOR'S WORK}

\author{
A project report \\ presented in partial fulfillment \\ of the requirements for the degree \\ Doctor of Ministry
}

by

Kenneth Lee Schander

APPROVAL BY THE COMMITTEE:

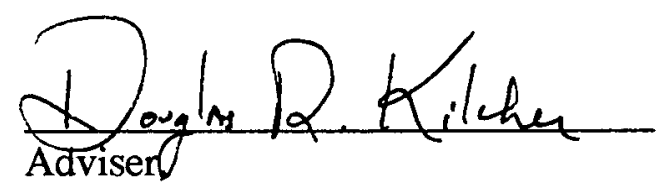

Douglas R. Kilcher

Dean,
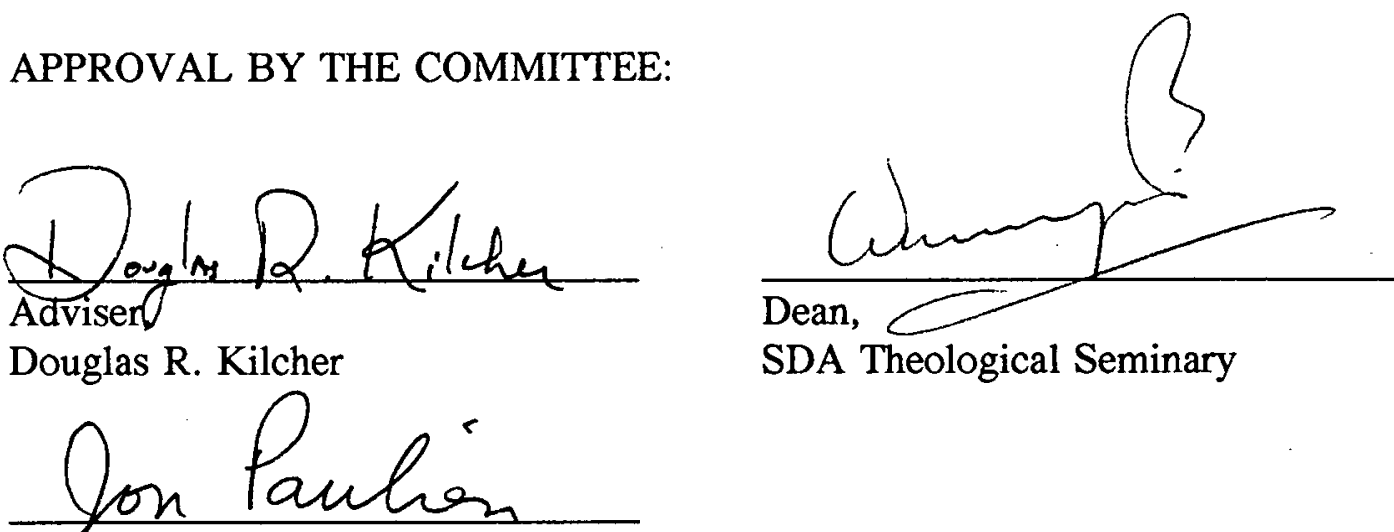

Jogethan K. Paulien

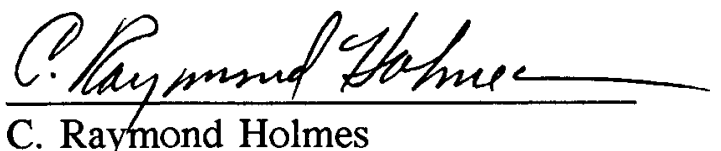

$\frac{\text { Apmil } 28,1994}{\text { Date approved }}$ 


\section{TABLE OF CONTENTS}

\section{Chapter}

I. INTRODUCTION $\ldots \ldots \ldots \ldots \ldots \ldots \ldots \ldots \ldots \ldots \ldots \ldots \ldots$

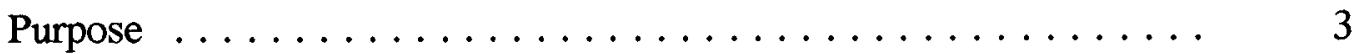

Justification for the Project $\ldots \ldots \ldots \ldots \ldots \ldots \ldots$

Limitations of the Project $\ldots \ldots \ldots \ldots \ldots \ldots \ldots \ldots$

Definition of Terms $\ldots \ldots \ldots \ldots \ldots \ldots \ldots \ldots \ldots \ldots$

Method $\ldots \ldots \ldots \ldots \ldots \ldots \ldots \ldots \ldots \ldots \ldots \ldots \ldots$

II. APOSTOLIC MINISTRY AND PRAYER: A BIBLICAL

PERSPECTIVE ....................... 12

The Origins of Apostolic Ministry . . . . . . . . . . . . 15

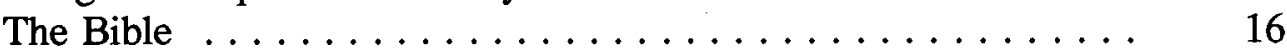

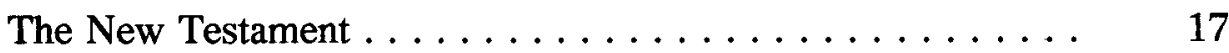

The Functions of Apostolic Ministry . . . . . . . . . . . . . . 22

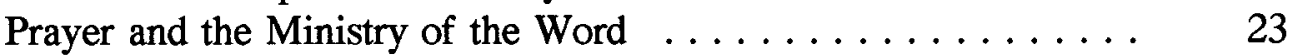

The Elders and Prayer . . . . . . . . . . . . . . . . . . . . . . 27

The Elder-Texts $\ldots \ldots \ldots \ldots \ldots \ldots \ldots \ldots \ldots$

The Meaning of Prayer $\ldots \ldots \ldots \ldots \ldots \ldots \ldots \ldots$

Summary ....................... 40

III. PASTORS AT WORK: LET THEM PRAY . . . . . . . . . . . . 43

A Qualitative Approach . . . . . . . . . . . . . . . . 46

Learning to Pray . . . . . . . . . . . . . . . . . . 48

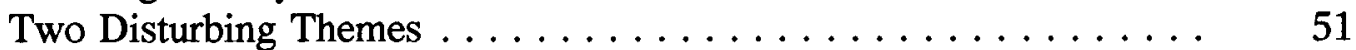

Feeling Guilty About Prayer . . . . . . . . . . . . . . . . . . . 52

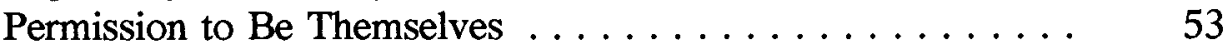

Pressured by the Expectations of Others . . . . . . . . . . 55

Pressured to Be Productive . . . . . . . . . . . . . . . . 60

Caught in the Tension Between Being and Doing .......... 64

A Means of Self-Justification ................ 67

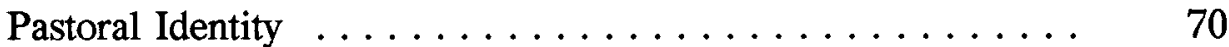

Prayer and the Pastor's Work .................. 73 


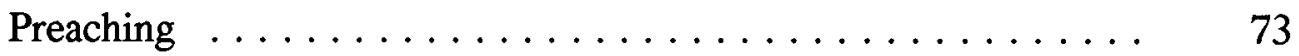

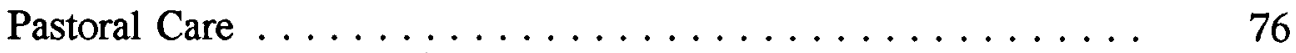

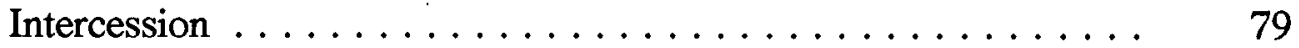

Prayer: The Pastor's Prime Work $\ldots \ldots \ldots \ldots \ldots \ldots \ldots \ldots \quad 82$

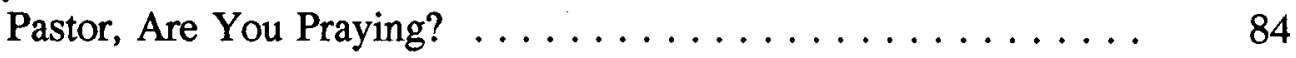

Rethinking the Pastor's Work $\ldots \ldots \ldots \ldots \ldots \ldots \ldots$

Consider My Friend Ben . . . . . . . . . . . . . . . 88

IV. RETHINKING MY ROLE AS A PASTOR $\ldots \ldots \ldots \ldots \ldots \ldots$.

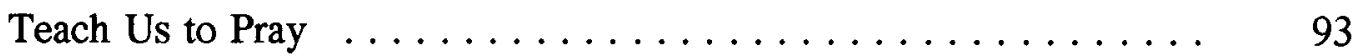

Three Models ......................... 96

The Twelve: The Priority of Prayer . . . . . . . . . . 96

Jesus: Between the Mountain and the Multitude . . . . . . . 99

Epaphras: His Work Was Prayer . . . . . . . . . . . . . 101

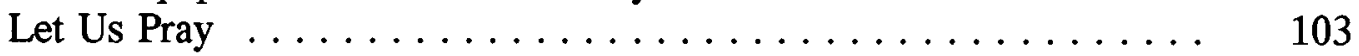

Three Things Are Needed . . . . . . . . . . . . . . 105

A Final Word $\ldots \ldots \ldots \ldots \ldots \ldots \ldots \ldots \ldots \ldots \ldots \ldots$

Appendix . . . . . . . . . . . . . . . . . . . . . 109

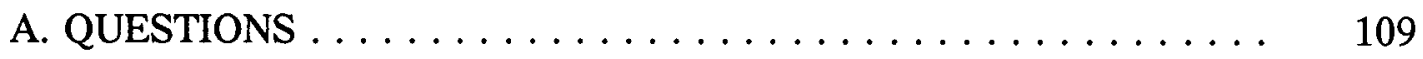

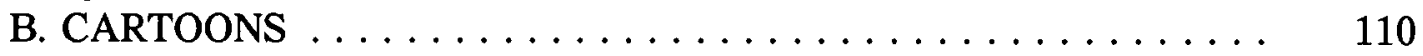

SELECTED BIBLIOGRAPHY $\ldots \ldots \ldots \ldots \ldots \ldots \ldots \ldots \ldots \ldots . \ldots \ldots$

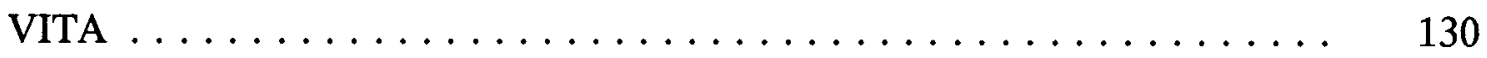




\section{CHAPTER I}

\section{INTRODUCTION}

When I heard God's call to ministry, the call was clear; however, the nature of the calling was not. That was nearly twenty-five years ago, and I am still trying to figure out what ministry is. My enrollment in seminary came on the heels of a period of great unrest in American culture. ${ }^{1}$ And as I was soon to discover, the work and role of the minister was changing along with nearly everything else. By the time I graduated, the so-called "ministerial identity crisis" was already well chronicled in the literature of pastoral theology. ${ }^{2}$

Two decades later John R. W. Stott wrote, "One feature of the contemporary church is its uncertainty about the role of its professional ministers." 3 His conclusion

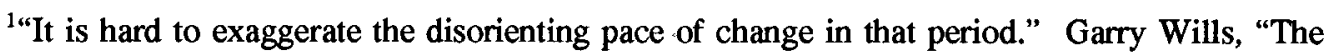
'60s: Tomado of Wrath," Newsweek, 3 January 1994, 40.

${ }^{2}$ See for instance H. Richard Niebuhr, The Purpose of the Church and Its Ministry (New York: Harper \& Bros., 1956), 50-51; Samuel W. Blizzard, "The Minister's Dilemma," The Christian Century, 25 April 1956, 508; Robert G. Middleton, "Let the Minister Be a Minister," Foundations 2, no. 3 (July 1959): 198; James D. Smart, The Rebirth of Ministry (Philadelphia: Westminster Press, 1960), 17-18; Harry G. Goodykoontz, The Minister in the Reformed Tradition (Richmond, VA: John Knox Press, 1963), 17; James D. Glasse, Profession: Minister (Nashville: Abingdon Press, 1968), 13; Robert G. Middleton, Privilege and Burden (Valley Forge, PA: Judson Press, 1969), 26-28; Gerard Meagher, introduction to Priest: Person and Ministry, ed. Gerard Meagher (Dublin: Gill and MacMillan, 1970), ix; Michael Ramsey, The Christian Priest Today (New York: Morehouse-Barlow, 1972), 1; Donald P. Smith, Clergy in the Cross Fire: Coping with Role Conflict in the Ministry (Philadelphia: Westminster Press, 1973), 15.
}

${ }^{3}$ John R. W. Stott, "Ideals of Pastoral Ministry," Bibliotheca Sacra 146, no. 581 (JanuaryMarch 1989): 3. 
confirms our failure to achieve consensus regarding the role of the minister in spite of decades of discussion and debate of the topic.

Among the first to describe the role conflict clergymen face was Samuel W. Blizzard. He identified “The Minister's Dilemma” thirty-eight years ago-a dilemma yet unresolved as ministers continue to be torn between the demands of their theology and training on one hand and the demands of their parish on the other. What Blizzard said about the 690 American Protestant clergymen he studied was, "The theology they hold and the seminary instruction they received place the roles they perform in the parish in one priority order. But they actually spend most of their time doing those things they feel are least important."

Blizzard's pioneering sociological study was corroborated by the research of others like Donald P. Smith who concluded that, "for most clergymen today, role ambiguity and role conflict are not matters of mere academic curiosity. Rather, these are the heart of the most difficult problems that the minister faces." ${ }^{2}$ That was twenty years ago. Writing as a pastor to pastors in the 1990s, Eugene H. Peterson observed, "It is not easy these days to figure out what it means to be a leader in Christ's church." ${ }^{3}$ The same point is taken a step further by J. David Bridge in an article on the pastor's priorities. He says,

Of all the tasks facing the ordained ministry today, none is more important than the discovery and sustaining of priorities which reflect the gospel we proclaim.

\footnotetext{
${ }^{1}$ Blizzard, 508.

${ }^{2}$ Smith, 15.

${ }^{3}$ Eugene H. Peterson, Under the Unpredictable Plant: An Exploration in Vocational Holiness (Grand Rapids: William B. Eerdmans Publishing Company, 1992; Leominster, England: Gracewing,
} 1992), 5. 
... If our conception of what a minister is lacks clarity, it is not surprising if our understanding of what a minister should be doing is vague."

Others have noted that the question of the minister's role continues to be one of the most critical and important issues facing the church today and is the subject of a growing body of literature. ${ }^{2}$ David L. Bartlett is not surprised by the many witnesses to the uncertainty of the church about the minister's vocation, and the eagerness of others to help us find our way. He says, "It does not take academic experts, however, to assure us of our uncertainty."3

While the minister's identity remains elusive, Sheldon A. Tostengard says,

One grows weary of endless talk of identity, but there is no question that it is a crucial issue for pastors in our time. It is difficult for a pastor to live with freedom and joy unless there is a clear sense of who the pastor is and what the central duties of ministry are. ${ }^{4}$

The nature of the minister's role is in transition. According to Gerard Meagher, "For some it is a time of confusion, threat and fear; for many it is a time of hope, promise and light." What will emerge as priorities for the pastor?

\section{Purpose}

The minister's identity is not an abstract or merely academic concern for me.

\section{'J. David Bridge, "The Pastor's Problems: VIII. The Pastor's Priorities," The Expository} Times 93, no. 2 (November 1981): 36.

${ }^{2}$ See Ben Campbell Johnson, Pastoral Spirituality: A Focus for Ministry (Philadelphia: Westminster Press, 1988), 7; and Robert E. Van Voorst, "Reforming Our Pastoral Ministry: An Essay on Role Conflict in the Ministerial Office," Reformed Review 46, no. 3 (Spring 1993): 189.

${ }^{3}$ David L. Bartlett, Ministry in the New Testament (Minneapolis: Fortress Press, 1993), 1. 1981): 356 .

${ }^{4}$ Sheldon A. Tostengard, "Preaching and the Pastoral Vocation," Word \& World 1, no. 4 (Fall

${ }^{5}$ Meagher, ix. 
This research project has been one step in my effort to resolve my own personal dilemma. As a minister I ask, "Who am I?" and "What am I to do?" I confess that I am unable to answer these basic questions of identity to my satisfaction. After two decades of ministry, it troubles me that I am not more sure of who I am and what I should be doing. I believe many of my ministerial colleagues share this ambivalence about our calling. But I take no comfort in their uncertainty.

The question is not, "Do I know what I am doing?" I think I can answer that question as well as the school teacher or banker, although perhaps not as definitively as the secretary or farmer. The question is, "Do I know what I am to do?" And my honest answer is, "No, I really do not know." This is my continuing dilemma.

Have I been living a charade? It is not that I can not perform the minister's many roles. Actually, I am quite proficient at them. But I confess to living with a dis-ease that comes from not being certain that what I do as a minister is what I really should be doing.

What should my work be as a minister? I would like to think that the answer lies not just in my parishioners' expectations of me, but in my Bible-particularly in the patterns of New Testament ministry. However, in spite of nearly 2000 years of our best efforts, the Christian church is still far from consensus on my role as a minister.

I agree with Eugene H. Peterson's assessment of what should be the pastor's priorities. He says, "The grand essentials for me are immersion in Scripture and pursuit of prayer."1 I also agree when he says, "Pastors have so many demands

${ }^{1}$ Eugene H. Peterson, "Return to the Timeless," Leadership 14, no. 2 (Spring 1993): 22. 
foisted upon them. They're easily distracted. The demands of others are wellmeaning and usually legitimate, but nobody's grabbing us and saying, 'Are you praying? Are you reading the Scripture?'"1

Should not someone grab me and my ministerial colleagues and demand, “Are you praying? Are you doing your work?" Prayer is the minister's work, or at least part of it. I believe a case can be made from the activities of the New Testament prototypes of the modern pastor- Jesus and His successors, the apostles and the elders/presbyters-that prayer should be a significant part of my work as a minister.

I am one minister whose continuing dilemma is found in the squeeze between what I believe Scripture teaches are my priorities and what my church feels is my work. In an attempt to resolve my personal dilemma, I have undertaken this investigation of prayer as the pastor's work.

\section{Justification for the Project}

The nature of the pastor's work has been debated throughout the history of the Christian church without consensus. In the more recent confusion over what constitutes the pastor's job, his call to be a person of prayer has been largely lost sight of. The literature in the fields of pastoral theology and biblical studies dealing with the work of the pastor reflects the current neglect of prayer as an important function of the pastor. A critical need exists for the church to do two things in this regard. We must (1) understand why this is the case, and (2) we must strive to

\footnotetext{
${ }^{1}$ Ibid., 23.
} 
reestablish prayer as a priority for the work of the churches' spiritual leaders.

\section{Limitations of the Project}

It may appear that my involvement in this project on prayer represents a claim on my part to be an exemplary model of the practice of prayer which I hold up as the ideal for the pastor. I assure you that I make no such claim. When writing about prayer, Loren E. Halvorson said he did so "with some hesitation. Though I have taught for many years in a theological seminary, I am very much in need of instruction in prayer. I am not alone." The truth is that I too have undertaken this project with considerable hesitation. Halvorson is not alone; although I have been a pastor for many years, I have a great and continuing need, as did Jesus' disciples, to be taught to pray.

\section{Definition of Terms}

My use of two common terms in this project report needs some explanation. They are: prayer and pastor.

1. Prayer. I understand prayer in its broadest sense as any communication between an individual and God. Prayer is always initiated by God and always includes our response. Thus prayer is always dialogical even when it does not involve intentional communication on our part. I picture prayer as a spectrum of communication that begins with our almost unconscious acknowledgement of God and extends to our very conscious dependence on Him. In this report the term

${ }^{1}$ Loren E. Halvorson, "Prayer and Action," in A Primer on Prayer, ed. Paul R. Sponheim (Philadelphia: Fortress Press, 1988), 98. 
prayer is used by others in a variety of more limited senses. I have made no attempt to provide a common definition.

2. Pastor. This is a title that is commonly used to designate the leader of a congregation. In the Bible the term pastor is used in this sense only in Eph 4. I use pastor interchangeably with minister, priest, bishop, and elder in this report to refer to the full-time, ordained spiritual leaders of churches.

\section{Method}

In their 1989 article, "The Doctorate of Ministry as an Exercise in Practical Theology: Qualitative Research with Living Human Documents," published in the Journal of Supervision and Training in Ministry, Bonnie J. Miller-McLemore and William R. Myers of Chicago Theological Seminary wrote:

Rarely does the minister have or take the time for critical reflection. . . . In part, Doctorate of Ministry programs are popular because they provide busy ministers the opportunity to engage in a sustained and intentional process of critical reflection regarding their personal practice of ministry. ${ }^{1}$

The opportunity to reflect critically on my own pastoral ministry was precisely the reason that I became involved in Doctor of Ministry studies. Miller-McLemore and Myers recommend qualitative research with "living human documents" as the best means to provide for critical reflection upon the variety of issues and problems that regularly occur within the actual practice of ministry. Their reference to the "living human documents" recalls the work of their predecessor at Chicago Theological Seminary, Anton Boisen. It is Boisen who "is generally considered the founder of

\footnotetext{
${ }^{1}$ Bonnie J. Miller-McLemore and William R. Myers, "The Doctorate of Ministry as an Exercise in Practical Theology: Qualitative Research with Living Human Documents," Journal of Supervision and Training in Ministry 11 (1989):5.
} 
clinical pastoral education in America." Boisen said, "What is new is the attempt to begin with the study of living human documents rather than with books and to focus attention upon those who are grappling desperately with the issues of spiritual life and death."2

In this project report, I reflect critically on the phenomenon of prayer as a part of my work and that of my fellow pastors. We certainly qualify as "living human documents" who are "grappling desperately with the issues of spiritual life and death.” Because I feel it is important to understand the perspective of my colleagues regarding this topic, I elected to do a qualitative study. Qualitative research is relatively uncommon in pastoral theology in spite of the many "living human documents" available for study which are part of ministry. ${ }^{3}$

Educational researcher, W. Philip Bassett provides this five-point definition of qualitative research:

1. Qualitative research focuses on discovery and seeks to gain insight into the complexity of phenomena by understanding their meaning from the perspective of those being studied.

2. Qualitative research is conducted in the natural setting of the events or people being studied.

\footnotetext{
${ }^{1}$ Charles V. Gerkin, The Living Human Document: Re-Visioning Pastoral Counseling in a Hermeneutical Mode (Nashville: Abingdon Press, 1984), 37.

${ }^{2}$ Anton T. Boisen, "The Period of Beginnings," The Journal of Pastoral Care 5, no. 1 (Spring 1951): 15.

${ }^{3}$ I am familiar with the following D.Min. projects which are qualitative studies: John C. Alspaugh, "The Caring Ministry: Concepts and Methods of Ministry to Inactive Members of the Stone Tower Seventh-day Adventist Church, Portland, Oregon" (D.Min. project report, Andrews University, Seventh-day Adventist Theological Seminary, 1986); George J. Didier III, "Vocational Crisis and Transformation: From Ordained Clerical Priesthood to Lay Ministry" in Creative Ministries in Contemporary Christianity, ed. Perry LeFevre and W. Widick Schroeder, Studies in Ministry and Parish Life (Chicago: Exploration Press, 1991); Humphrey Joseph Murphy, "A Qualitative Study of Work Satisfaction Among Archdiocesan Associate Pastors in Team and Traditional Style Urban Parochial Ministries" (D.Min. project report, Boston University School of Theology, 1981).
} 
3. Qualitative research uses the researcher as the primary instrument to collect data in the form of field notes based on observations and interviews that consider processes as well as outcomes.

4. Qualitative research analyzes data inductively with the goal of defining and interpreting events from the perspective of those being studied. Analysis seeks to draw out themes and classifications that are inherent in the data of the research situation.

5. Qualitative research is reported in the narrative form, frequently using extended quotations from field notes. It includes the complexity and ambiguity found in the situation under study. ${ }^{1}$

Pastors need to be heard. Frequently they are not even given a part in the discussions of their own work. Author and pastor, John Robert McFarland says,

Parish ministers are seen as consumers only. In most journals or conferences for parish ministry, not half of the articles or workshops are written or conducted by parish ministers. It seems that the only requirement for teaching parish ministers is not to be one. On the other hand, parish ministers are rarely asked to write for journals or present papers or workshops at conferences for professors or chaplains. This implies that parish ministers know little about their own profession, and have nothing to contribute to their peers. It is not what the seminary professes, but it's what we were taught. ${ }^{2}$

Qualitative research provides the best means for pastors to be heard from their own perspective. Bassett's fifth point, in which he says the research is reported in narrative form, makes it especially challenging to write a report like this and to make it readable to the layperson, as well as credible to the professional. Dealing with the complexity and ambiguity of the situation under study multiples this difficulty. The reader needs to understand that there may not be an obvious spatial or time sequence which gives the story unity.

Bassett describes the researcher as "the primary instrument to collect data" in

\footnotetext{
${ }^{1}$ W. Philip Bassett, "Classroom Implementation of Cooperative Learning: Qualitative Case Studies of Three Early Elementary Teachers" (Ph.D. dissertation, Andrews University, School of Education, 1991), 33-34.
}

${ }^{2}$ John Robert McFarland, "Neglecting Parish Pastors," The Christian Ministry 21, no. 2 (March-April 1990): 11. 
qualitative research. Part of what it means for me, as the researcher, to be "the primary instrument" is that I share the story told by my fellow pastors. Their story is also my story. One author put it this way,

The researcher himself becomes part of the object of inquiry. The researcher in becoming involved with his subjects, enters into their world and engages them in mutually reflective activity. He questions his subjects and himself. Reflection by himself and participants allows new questions to emerge which, in turn, leads to more reflection. In the ongoing process which is dialectical and transformative, both researcher and subject become participants in an open dialogue.

Can the subjective data collected through qualitative research reflect reality? That, of course, depends on how reality is understood. Qualitative research assumes multiple reality. There can be more than one truth observed in a given incident. It is also helpful to appreciate what Vaclav Havel, then president of Czechoslovakia, is reported to have said: "We must see the pluralism of the world and not blind it by seeking common denominators. We must try harder to understand than explain."2 The late theologian and anthropologist, Urban T. Holmes III said,

We have been seduced by our socialization into thinking that all truth is susceptible to scientific analysis (as in the natural sciences). Such analysis reduces all experience to numbers, which are then manipulated in the service of objectivity, prediction, and control. But these three values are incapable of explaining the mystery of human relationship. The fact of the matter is that scientific methodology does not describe reality or any part of it; it only builds models, which are subject to constant revision and are occasionally contradictory to one another. ${ }^{3}$

The scientific search for objectivity is an elusive ideal. The value of qualitative

\footnotetext{
${ }^{1}$ Ted T. Aoki, Toward Curriculum Inquiry in a New Key, Curriculum Praxis, no. 2 (Edmonton, Alberta, Canada: Publication Services, 1988), 17.

${ }^{2}$ Vaclav Havel, speech given to the World Economics Forum in Davos, Switzerland, 1992.

${ }^{3}$ Urban T. Holmes III, Spirituality for Ministry (San Francisco: Harper \& Row, Publishers, 1982), 14
} 
research is that it allows us to experience our world in a greater variety of ways.

The results of my study of prayer as a part of the pastor's work are presented from two viewpoints. The first is the biblical perspective. The second view is that of five of my pastoral colleagues from a variety of Christian faiths. Both perspectives reflect what I believe is a qualitative approach to research.

In my biblical study, I ask the question: What did the New Testament ministers do in the settings in which they worked? The answer is provided by both their words and their actions. What did they do? I show that prayer is a significant part of what they did. To determine the understanding contemporary pastors have of prayer as a part of their work, I selected a "purposive sample" of five of my colleagues to interview. I did not attempt to quantify the "unquantifiable" by asking them how frequently they prayed. ${ }^{1}$ I just listened as they told me the stories of how prayer is a part of their work as pastors.

My personal search for a ministerial identity led me to this study. I am convinced that prayer is central to pastoral identity and work. It is my hope in this project to become part of the conversation in pastoral theology that will determine the future shape of the parish pastor's work.

${ }^{1}$ David L. Goetz, "How Pastors Practice the Presence," Leadership 14, no. 4 (Fall 1993): 28. There is a place for the objective study undertaken by Goetz, but there is also a need for a more subjective approach to the subject. 


\section{CHAPTER II}

\section{APOSTOLIC MINISTRY AND PRAYER}

\section{A BIBLICAL PERSPECTIVE}

What should the pastor do? The church relies on pastoral theology to identify the work of its' pastors. In this chapter I intend to address one facet of the pastor's work-prayer-from the biblical perspective. The Bible is the place to begin this investigation, but how does one approach a subject which has been the focus of study for so long and by so many?

I propose to approach the subject of prayer as part of the pastor's work "from below." The expression "from below" means different things to different people. Urban T. Holmes III, wrote of the need for a pastoral theology done "from below." He was looking for a theology "that begins where we are."1 Holmes' conviction "that theology moves from humanity to God and not from God to humanity" is similar to what Edward Schillebeeckx had in mind when he said that ministry "developed spontaneously from below" but was received as "from above." Following Schillebeeckx, William H. Willimon maintains that, "Leadership arises

${ }^{1}$ Holmes, 5.

${ }^{2}$ Ibid., 11.

${ }^{3}$ Edward Schillebeeckx, Ministry: Leadership in the Community of Jesus Christ, trans. John Bowden (New York: Crossroad, 1981), 5. 
from 'below' not from 'above'-by dribbling down from God to Jesus, to the Bishop through the hierarchy, to the clergy, at last to the lowly laity. . . At the same time leadership is from above, a gift of the Lord."

My proposal to approach this one dimension of pastoral theology "from below" is not an endorsement of the positions held by these theologians. And yet there is a sense in which ministry is defined "from below." I use the term "from below" to indicate that our understanding of ministry in the early church cannot come simply "from above," that is, from its formal definitions; it must also reflect that which came "from below," that is, the actions of the ministers described in the New Testament. To do pastoral theology "from below" I propose to begin, not "where we are," but where our predecessors, the first ministers, served Christ and His church.

Such a theology "from below" might be called "grounded theology" after the "grounded theory" proposed by Barney G. Glaser and Anselm L. Strauss for understanding research in the social sciences. ${ }^{2}$ Rather than imposing a theory from the start the researcher needs to be open to what the data has to tell us and allow for a coherent framework for understanding to evolve from it. My "theory" that prayer was, and should continue to be, central to the work of the minister is hardly new. I believe, however, that my approach to this subject "grounds" theory in the New Testament data in a way that gives even greater credibility to the understanding of

\footnotetext{
${ }^{1}$ William H. Willimon, Acts, Interpretation: A Bible Commentary for Teaching and Preaching (Atlanta: John Knox Press, 1988), 59.

${ }^{2}$ Barney G. Glaser and Anselm L. Strauss, The Discovery of Grounded Theory: Strategies for Qualitative Research (Chicago: Adline, 1967).
} 
the pastor as a person of prayer.

This attempt to derive an understanding of the place of prayer in ministry from its practice can also be described as qualitative research. I want to understand what New Testament ministers did in the settings in which they worked. ${ }^{1}$ No possibility exists, of course, for me to interview the first practitioners of ministry. However, their vocational self-understanding is reflected not only in the written records of what they said, but more importantly also in what they did.

I believe an understanding of the place of prayer in the work of the pastor can best be derived from its practice as observed in the New Testament church. Actual praxis in the early church expressed a view of ministry that may not only be different from current ecclesiastical practice but may also differ from the more formal definitions of ministry found in the New Testament. Keith Watkins observes that "the de facto doctrine of ministry and the de jure doctrine may not be the same." What I am wanting to discover is the de facto doctrine of ministry as seen in actual practice as opposed to the de jure doctrine prescribed by pronouncements from above. I do not necessarily see the two as being different. It is, in fact, more likely that they are complementary. What is needed though is to see this issue from both perspectives, "from below" as well as "from above."

${ }^{1}$ Educator Elliot W. Eisner's comment is apropos here: "If qualitative inquiry in education is about anything, it is about trying to understand what teachers and children do in the settings in which they work." Eisner's words could be applicable to the field of pastoral theology if paraphrased as follows: "If qualitative inquiry in pastoral theology is about anything, it is about trying to understand what ministers do in the settings in which they work." Elliot W. Eisner, The Enlightened Eye: Qualitative Inquiry and the Enhancement of Educational Practice (New York: Macmillan Publishing Company; Toronto: Collier Macmillan Canada, 1991), 11.

${ }^{2}$ Keith Watkins, "Ministers and Elders as Leaders of Worship in the Christian Church," Encounter 39, no. 3 (Summer 1978): 305. 
What did the New Testament ministers do? That is the question I want to answer. A comprehensive account of their functions is beyond the scope of this study which is limited only to prayer as a part of the pastor's work. The question can be answered in part quite simply and unequivocally: the church's first ministers prayed. Bonnie Thurston says definitively, "Prayer is the prominent characteristic of the spiritual leadership of the early church as described in Acts."1

This understanding of the pastor's work emerges from "the foundational documents for the life of the church and for the vocation of its clergy-the visions found in the Bible, and particularly in the New Testament."2 It is important that the church be reminded that prayer was a fundamental characteristic of New Testament ministry, especially at this time when our understanding of the work of the minister is undergoing such extensive reappraisal.

\section{The Origins of Apostolic Ministry}

All Christian ministry derives in some form from that of the apostles. ${ }^{3}$ This assumption is fundamental to the study of the contemporary pastor's role and could

${ }^{1}$ Bonnie Thurston, Spiritual Life in the Early Church: The Witness of Acts and Ephesians (Minneapolis: Fortress Press, 1993), 56. Thurston goes further than Trites who says, "Prayer is $a$ prominent characteristic in the spiritual leadership of the early church" (italics mine). Allison A. Trites, "The Prayer Motif in Luke-Acts," in Perspectives on Luke-Acts, ed. Charles H. Talbert (Danville, VA: Association of Baptist Professors of Religion, 1978), 185.

${ }^{2}$ Bartlett, 2.

${ }^{3}$ This much can be affirmed without this inquiry being derailed by the divisive issues of church polity which are reflected in much of the scholarly research on the origins of ministry. According to Richard A. Norris, Jr., "Most inquiries into the origins of Christian priesthood have been directly or indirectly informed by polemical or apologetic motives." Richard A. Norris, Jr., "The Beginnings of Christian Priesthood," Anglican Theological Review 66, Supplementary Series no. 9 (1984): 18. Johannes Munck goes further saying, "All scholars bring to the study of New Testament origins and history preconceptions from their own confessional background." Johannes Munck, The Acts of the Apostles: Introduction, Translation and Notes, revised by William F. Albright and C. S. Mann, The Anchor Bible, vol. 31 (Garden City, NY: Doubleday \& Company, 1967), 276. 
be the one aspect of the minister's confused identity about which there is no need for uncertainty. Today's pastors may be unsure of who they are; they do not, however, need to question the apostolic origin of ministry. ${ }^{1}$ All Christian churches claim that their ministers are successors to the ministry Christ entrusted to the Twelve. ${ }^{2}$

\section{The Bible}

Reference to the apostles directs us to the Bible; it is there, according to

Eugene H. Peterson, that "pastoral work properly originates, as does all Christian ministry." ${ }^{3}$ Acknowledging the Bible as the source of our ministry is imperative, but it will not necessarily alleviate the role confusion modern clergy have experienced. There are two reasons which account for this. John J. Ziegler describes our present understanding of ministry as "the fruit of a development which originated in the New Testament." ${ }^{4}$ The great distance between our time and that of the biblical sources and the changes which have occurred during that time is the first reason why

${ }^{1}$ According to William R. Herzog II, "The writers of the New Testament and the Apostolic Fathers believed all forms of ministry were apostolic in nature." William R. Herzog II, "The Origins of Ministry in the New Testament," American Baptist Quarterly 3, no. 2 (June 1984): 118.

${ }^{2}$ While acknowledging the various forms in which it is held, Robert Paul says, "All Christian churches believe in apostolic succession." Robert S Paul, Ministry (Grand Rapids: William B. Eerdmans Publishing Company, 1965), 191. Of interest to my own denomination (Seventh-day Adventist) would be the apparent support for this position by Ellen G. White. She wrote: "He [Christ] has ordained that there should be a succession of men who derive authority from the first teachers of the faith." Ellen G. White, Testimonies for the Church, vol. 4 (Mountain View, CA: Pacific Press Publishing Association, 1948), 529.

${ }^{3}$ Eugene H. Peterson, Five Smooth Stones for Pastoral Work (Atlanta: John Knox Press, 1980), 11.

${ }^{4} J o h n$ J. Ziegler, "Who Can Anoint the Sick," Worship 61, no. 1 (January 1987): 30. The landmark World Council of Churches document, Baptism, Eucharist and Ministry, bears witness to a growing acceptance of the understanding that present forms of ministry are the result of evolutionary development and that they are not prescribed in the New Testament. Baptism, Eucharist and Ministry. Faith and Order Paper No. 111 (Geneva: World Council of Churches, 1982), 22, 24. 
consulting them can still leave us wondering what ministry is all about. The second reason, according to Harry G. Goodykoontz, is also "a major reason for the minister's fuzzy self-image." He points out "that there is no clear statement in the Bible concerning the nature of the ministry." ${ }^{1}$ As much as we may wish otherwise, the biblical data regarding the role of the minister is enough to point us in the right direction but does not answer all our questions. ${ }^{2}$ The limits of the biblical sources cannot be put aside; nevertheless, the appropriate starting point for consideration of ministry today is still an understanding of the patterns that are found in the New Testament. $^{3}$

\section{The New Testament}

The importance of the New Testament data to the understanding of the work of today's ministry is articulated by James W. Thompson, who says:

A study of ministry in the New Testament is motivated by more than antiquarian interests. The continuing scholarly concern over the question reflects the uncertainty and controversy over ministerial role models and the desire for the contemporary church to find appropriate paradigms in the New Testament. This controversy over ministerial functions reflects fundamental differences

\footnotetext{
${ }^{1}$ Goodykoontz, 17. Goodykoontz's comment is part of his chapter, "The Biblical View of the Ministry." In the paragraph from which I quote he continues, "The Bible says many things about the ministry, but nothing definitive. Able scholars differ in their interpretations. Is the ministry primarily an office or a function, or is it both? ... Is apostolic succession plain nonsense or does the concept contain basic truth? Such questions arouse strong emotions. Pure objectivity is impossible. The biblical scholar who thinks he is objective is certain to be influenced more than he realizes by his own denominational background, by the age in which he lives, and by his own psychological conditioning. In this, the scholar is not being dishonest, he is simply being human."

${ }^{2}$ The texts tell us practically nothing about what the precise functions of the leaders of the early Christian communities were. J. T. Forestell says, "It is important to keep these limitations of historical research in mind in constructing a theology of ministry on the basis of the NT texts." J. T. Forestell, As Ministers of Christ: The Christological Dimension of Ministry in the New Testament: An Exegetical and Theological Study (New York: Paulist Press, 1991 ), 7.
}

${ }^{3}$ B. W. Powers, "Patterns of New Testament Ministry-1. Elders," The Churchman 87, no. 3 (Autumn 1973): 166. 
among religious traditions of the nature and task of the church and the primary functions of its leaders. ...

Confusion over ministerial models is derived today not only from the biases of diverse traditions. We have seen a shift in the paradigm in many traditions toward a new interest in the functions of the minister as counselor, administrator, social critic, and helper of the needy in addition to the traditional functions of preaching and teaching. The many conflicting paradigms are undoubtedly a source of confusion for both minister and congregation, leading to renewed interest in the evidence of the New Testament. ${ }^{1}$

Does the New Testament provide "appropriate paradigms" for the practice of ministry today? The question raised is the old one of whether the patterns found there should in any way be taken as normative for present practice. ${ }^{2}$ I recognize that the precise way in which the New Testament is normative for the church of all time is a difficult question. However, I still believe there are dimensions of the New Testament experience which provide standards for the exercise of ministry today.

\section{Jesus Christ}

George Carey argues that "New Testament ministry takes its starting-point from Jesus and his ministry. Properly speaking, an apostolic succession is not 'high' enough." In fact, "the communities of the New Testament seem to have ordered their leadership in service to the overriding goal of extending the ministry of Jesus Christ." ${ }^{4}$ This is precisely the point James D. Smart makes when he says, (1984): 143.

${ }^{1}$ James W. Thompson, "Ministry in the New Testament," Restoration Quarterly 27, no. 3

${ }^{2}$ Michael Root, "Called to the Office of Ministry: The New Testament and Today," Currents in Theology and Mission 12, no. 2 (April 1985): 157. (1982): 37 .

${ }^{3}$ George Carey, "The Origins of the Threefold Christian Ministry," Churchman 96, no. 1 43.

${ }^{4}$ Jeffrey P. Mickle, “Toward a Revised Diaconate," Quarterly Review 2, no. 1 (Spring 1982): 
The apostolic ministry, then, in which the Christian ministry receives its decisive formulation, is simply the ministry of Jesus Christ being continued, expanded, and carried ever farther afield in the world as Jesus Christ lives and speaks and acts redemptively through his ministers. ${ }^{1}$

Just as all Christian ministry derives from that of the apostles, so its origin is ultimately traced back even further to that of Jesus Christ. According to Jerome D. Quinn, Jesus "is the prototype and paradigm of apostleship." In the same way in which all churches agree regarding some sort of apostolic succession, they also all admit in some form the principle that Christ alone is the ultimate source of ministry in the church. His unique ministry was passed on to the apostles whose ministry was also "unique and unrepeatable."

The New Testament does not tell us all that we might like to know about the origins and functions of ministry. J. T. Forestell underscores what is most critical, however, when he writes:

The most that can be said with any kind of historical confidence is that there were in the NT churches individuals who exercised leadership roles and that among the functions of these leadership roles was that of perpetuating what had already been given by Christ to the apostles. ${ }^{4}$

At this point the fairly obvious trail we are following divides into several less clearly defined paths. Where we go from here is the truly fuzzy part of the minister's identity. Students of the history of ministry are familiar with the difficulty concerning the next step to be taken after acknowledging ministry's beginning in the

${ }^{1}$ Smart, 37.

${ }^{2}$ Jerome D. Quinn, "Apostolic Ministry and Apostolic Prayer," The Catholic Biblical Quarterly 33 (1971): 487.

${ }^{3}$ Baptism, Eucharist and Ministry, 21.

${ }^{4}$ Forestell, 89. 
biblical account of the ministry of Jesus and His apostles.

\section{The elders/presbyters}

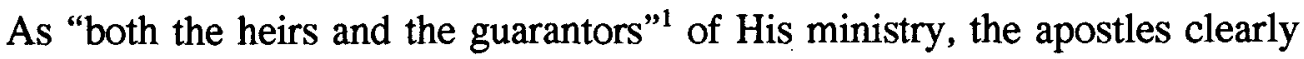
"serve to link the Church with the ministry of Jesus." But who, after the apostles, provides the next link in the chain which extends all the way to our day? Rather than there being a single pattern, there are a variety of forms of ministry, analogous to the modern pastoral office in the New Testament. ${ }^{3}$ Jerry R. Young provides a concise overview of the

three words in the Greek NT that dominate any discussion of the pastoral role:

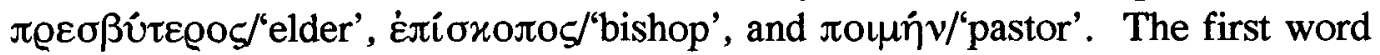
seems to describe a person who is characterized by maturity and dignity. The second word refers to a person who is charged with the duty or function of supervision. The third word refers to a person who leads and cares for sheep. All three words may be found in combination with one another. ${ }^{4}$

This complex relationship that we see between elder, bishop, and pastor in the New Testament is one reason differing views on church leadership exist. Whether these terms describe distinct ministerial offices or whether they are interchangeable designations which all refer to the same single office continues to be argued without consensus in the Christian church. But what is undeniable is that it is the elder/presbyter who "is the minister who meets us most frequently in the pages of

\footnotetext{
${ }^{1}$ Bartlett, 121.
}

${ }^{2}$ Steven Frederick Plymale, "The Prayer Texts of Luke-Acts" (Ph.D. diss., Northwestern University, 1986), 149.

3"The New Testament does not describe a single pattem of ministry which might serve as a blueprint or continuing norm for all future ministry in the Church. In the New Testament there appears rather a variety of forms which existed at different places and times." Baptism. Eucharist and Ministry, 24.

${ }^{4}$ Jerry R. Young, "Shepherds, Lead!" Grace Theological Journal 6, no. 2 (1985): 330. 
the New Testament." ${ }^{1}$ And according to the traditional understanding "these

'presbyters' were the local clergy, the teachers and pastoral and liturgical leaders."'

It is the elders, or the presbyters, who succeed the apostles. This position was taken as early as Irenaeus (c. 130-c. 200), who "constantly spoke of the presbyters who possess the succession from the Apostles."

There are scholars who go as far as to identify the apostles as "the first elders of the church." If this position is taken, then the elders can rightly be "regarded as the guardians of the apostolic tradition." 5 I believe that it was the elders who took up where the apostles left off. ${ }^{6}$

The titles most often used by the modern church for its clergy are clearly intended to identify them with the elder/presbyter of the New Testament and hence

${ }^{1}$ Michael Green, Called to Serve: Ministry and Minsters in the Church (Philadelphia: Westminster Press, 1964), 35.

${ }^{2}$ Ramsey, 4.

${ }^{3}$ Jeffrey G. Sobosan, "The Role of the Presbyter: An Investigation into the Adversus Haereses of Saint Irenaeus," Scottish Joumal of Theology 27, no. 2 (May 1974): 146.

${ }^{4}$ Powers, 170. This position is held by other scholars as well. For example, D. Edmond Hiebert, "Counsel for Christ's Under-Shepherds: An Exposition of 1 Peter 5:1-4," Bibliotheca Sacra 139, no. 556 (October-December 1982): 332, says, "The apostolic office included the work of the elders." George W. Knight III, "Two Offices (Elders/Bishops and Deacons) and Two Orders of Elders (Preaching/Teaching Elders and Ruling Elders): A New Testament Study," Presbyterion: Covenant Seminary Review 11, no. 1 (Spring 1985): 4, speaks of "the apostles (fellow elders)." B. E. Thiering, "Mebaqqer and Episkopos in the Light of the Temple Scroll," Journal of Biblical Literature 100, no. 1 (March 1981): 73, says, "the Jerusalem apostles are elders."

${ }^{5}$ Eduard Schweizer, Church Order in the New Testament, Studies in Biblical Theology, 32, trans. Frank Clarke (Naperville, IL: Alec R. Allenson, 1961), 200.

${ }^{6} \mathrm{I}$ am aware of the opposing views held by scholars regarding this point. Raymond E. Brown contends, "there is justification for the claim that the presbyter-bishops succeeded to the Pauline apostle in terms of pastoral care." Raymond E. Brown, Priest and Bishop: Biblical Reflections (New York: Paulist Press, 1970), 64. Bernard Cooke counters, "there is no evidence that the presbyteroi were looked upon as successors of the Twelve in their pastoral role." Bernard Cooke, Ministry to Word and Sacraments: History and Theology (Philadelphia: Fortress Press, 1976), 44. 
with apostolic ministry. According to Ronald E. Osborn, "The great majority of authorized ministers, in virtually all Christian churches, hold the office of presbyter (elder)." Today's pastors are seen as the successors to the ministry of the apostles.

In summary we note the comments of James D. Smart:

If we want to know what our ministry is, we must go to the Scriptures and trace out the line that runs from the Old Testament ministry through the ministry of Jesus and directly forward through the ministry of the apostles and so across the centuries to us. The supreme test of any ministry that claims to be Christian is whether or not it is a valid continuation of that line. ${ }^{2}$

\section{The Functions of Apostolic Ministry}

Disagreement exists among the churches over what constitutes ministry that is truly apostolic. Apostolic ministry can refer to doctrinal or functional succession to the apostles and is by no means limited to the more controversial view of the Roman Catholic Church which "claims that the apostles ordained the bishops to succeed them, and that the historic episcopate, stretching in unbroken succession back to the apostles, is essential to the Church." ${ }^{3}$ Protestants have generally subscribed to the view that the minister is functionally a successor of the apostles. ${ }^{4}$ This position

${ }^{1}$ Ronald E. Osborn, “The Ordination of the Presbyter," Study Encounter 6, no. 4 (1970): 193. Kevin Giles is more specific when he says, "In the historic, mainline churches, generally the ordained leaders of local congregations are identified with the presbyter/elder of New Testament days. In Roman Catholic, Orthodox and some Anglican opinion, the office of presbyter is directly equated with that of priest." Kevin Giles, Patterns of Ministry Among the First Christians (Melbourne: Collins Dove, 1989), 71. Gisbert Greshake points out that "the word 'priest' is actually derived from the Greek word presbyteros (=elder)." Gisbert Greshake, The Meaning of Christian Priesthood, with a foreword by Desmond Connell, trans. Peadar MacSeumais (Dublin: Four Courts Press, 1988), 42. In my own denomination, "elder" is the title used for ordained clergy.

${ }^{2}$ Smart, 20.

${ }^{3}$ Green, 63.

${ }^{4}$ See for instance, P. T. Forsyth, The Church and the Sacraments (London: Independent Press, 1917), 138. 
holds that

the apostles provide the essential foundation for the later ministry of the church, but their own ministry does not continue. It is unique and irreplaceable. Their particular office is not passed on by the laying of hands, but ends with their death. Their kerygma is passed on and becomes the basis for the mission of the church that succeeds them. ${ }^{1}$

The case for functional succession provides another line of compelling evidence to reinforce the conclusion that it was the New Testament elders who were the successors to the apostolic ministry. The praying of the elders, as shown below, is one function which provides obvious continuity to the ministry of the apostles.

\section{Prayer and the Ministry of the Word}

What did the apostles do as the first New Testament ministers? According to Richard A. Norris, Jr., "their role is notoriously difficult to assess." ${ }^{2}$ In spite of the difficulty, I believe our understanding of the functions of the apostles can be clarified by a study of Acts $6: 1-4 .^{3}$ This passage is crucial for our understanding of ministry and deserves careful consideration. In describing the historical setting of Acts 6, William H. Willimon says: "A new challenge has arisen within the community. The community is multiplying and new organization and leadership are needed." When the Jerusalem church chose "seven men ... full of the Spirit and wisdom" (vs. 3) to assist the Twelve, they made a division of labor which "rendered more explicit its

\footnotetext{
${ }^{1}$ Bartlett, 123.

${ }^{2}$ Norris, 21.

${ }^{3}$ The Bible version used in this project report is the New International Version unless otherwise noted.

${ }^{4}$ Willimon, 58.
} 
understanding of the apostolic office." ${ }^{1}$ This pericope is important precisely because Luke "uses it to sharpen his concept of an apostle."2 Here he delineates "prayer and the ministry of the word" (vs. 4) as the core tasks of apostolic ministry.

The episode recounted by Luke in Acts 6:1-4 focuses on a highly significant moment in the development of the ministry in the early church. The conflict between "the Grecian Jews [and] . . . the Aramaic-speaking community because their widows were being overlooked in the daily distribution of food" (vs. 1) prompted a refinement in the definition of the apostles' work. The apostles place before the believers a matter of priority: "It would not be right for us to neglect the ministry of the word of God in order to wait on tables" (vs. 2). There is more of consequence here than simply the handing over of the table service to the seven. ${ }^{3}$ And as significant as "the ministry of the word" is, prayer is given even greater prominence. Jerome D. Quinn points out that prayer was "the first task imposed by the Gospel and consequently the primary work of the Twelve."4

It was in Acts 6:1-4 that "for the first time persons other than apostles are given a leadership function" ${ }^{25}$ in the Jerusalem church. In this important narrative,

${ }^{1}$ Luke T. Johnson, Decision Making in the Church: A Biblical Model (Philadelphia: Fortress Press, 1983), 65.

${ }^{2}$ Joseph T. Lienhard, “Acts 6:1-6: A Redactional View,” The Catholic Biblical Quarterly 37, no. 2 (April 1975): 235.

${ }^{3}$ As important as they may be, the concerns regarding cultural divisions within the early church and the identity of the "seven" which dominate the discussion of this passage in the literature are not immediately relevant to our discussion.

${ }^{4}$ Quinn, 487, n. 39.

5John Maxwell Andrewartha, "Elder, Bishop, Pastor: A Descriptive Study of the Terms and Their Implications for a Contemporary Ecclesiology" (Ph.D. diss., Southwestern Baptist Theological Seminary, 1989), 146. 
Forestell says we have a description of "how the twelve communicated a share of their responsibility and authority to others during their own lifetime."' However, H. Armin Moellering maintains that "what the apostles are doing in Acts 6:1ff., is not making arrangements to share their office but to safeguard it." ${ }^{2}$ For the apostles, prayer and proclamation are of first importance and must take precedence over social work. $^{3}$ This is why the responsibility "to wait on tables" (vs. 2) was turned over to the seven men chosen for that purpose while the Twelve commit themselves to give their "attention to prayer and the ministry of the word" (vs. 4).

In this defining scene, prayer is established as a significant function of apostolic ministry. While both prayer and the ministry of the Word are mentioned as "the Apostolic functions," Percy G. Parker invites us to "notice that prayer came first-the ministry of the Word afterwards." In his doctoral dissertation on the prayer texts of Luke-Acts Steven Frederick Plymale makes this same observation and also speaks of prayer as an apostolic function:

Luke's view of the crucial importance of prayer is obvious as he describes the Apostolic function. Prayer is mentioned first: the Apostles say, "we will devote ourselves to prayer and the ministry of the word" (Acts 6.4). The word order might seem strange in view of the commissioning given them by Jesus that "repentance and forgiveness of sins should be preached in his name to all nations" (Lk. 24.47) and that the Apostles should be his witnesses "to the end of

${ }^{1}$ Forestell, 90.

${ }^{2} \mathrm{H}$. Armin Moellering, "Some New Testament Aspects of the Ministry Identified and Applied," Concordia Journal 14, no. 3 (July 1988): 238. 1981), 28.

${ }^{3}$ James Monroe Bamett, The Diaconate: A Full and Equal Order (New York: Seabury Press,

${ }^{4}$ Plymale, 7.

${ }^{5}$ Percy G. Parker, An Acceptable Minister of Christ (Philadelphia: Sunday School Times Company, 1924), 60 . 
the earth" (Acts 1.8). But Luke is convinced that the ability of the Apostles and others to carry out their role within the salvific plan depends upon their prayer life. $^{1}$

My study of Acts 6:1-4 confirms John J. Navone's conclusion, "Prayer is the special obligation of the Twelve." "The work which the apostles must do is, first, to be constantly in prayer," according to Simon J. Kistemaker. ${ }^{3}$ Is this understanding of the centrality of prayer in apostleship simply the result of theological reflection of this one passage? No, I believe this conclusion is also supported by the evidence of additional prayer texts in Acts. In fact, it is exactly how Luke portrays the apostles and the church. As quoted previously, Thurston says, "Prayer is the prominent characteristic of the spiritual leadership of the early church." "They are said to be "constantly in prayer" (1:14) in the upstairs room while awaiting the promised Holy Spirit. They "devoted . .. themselves to prayer" (2:42) following the addition of three thousand new believers at Pentecost. And again they raise "their voices together in prayer to God" (4:24) after the release of Peter and John from jail. So when we come to the critical moment in the early history of the church described in Acts 6:1-4 we see the Twelve solemnly rededicating themselves to "this apostolic ministry" (1:25) of "prayer and the ministry of the word" (6:4)..$^{5}$

In his discussion of Acts 6, Bartlett asks, "Do the apostles now point ahead to

${ }^{1}$ Plymale, 214-215.

${ }^{2}$ John J. Navone, Themes of St. Luke (Rome: Gregorian University Press, 1970), 124.

${ }^{3}$ Simon J. Kistemaker, The New Testament Commentary: Exposition of the Acts of the Apostles (Grand Rapids: Baker Book House, 1990), 222.

${ }^{4}$ Thurston, 56.

${ }^{5} J o h n$ N. Collins, Diakonia: Re-interoreting the Ancient Sources (New York: Oxford University Press, 1990), 230. 
later elders?"' I believe they do.

The Elders and Prayer

We have already seen that the leadership first given to the apostles was taken over by the elders who stand in a line of functional succession to them. ${ }^{2}$ The identity of the apostolic functions may not be universally agreed upon. However, that does not concern me here. I simply want to reiterate that whatever the apostolic functions were which were passed on to the elders, they included the important ministry of prayer.

Eduard Schweizer correctly points out that "it is not easy to decide exactly what the elders' ministry was." ${ }^{3}$ So how can we agree that prayer, or anything else, was a function of their ministry when "there is no scholarly consensus on the exact functions of presbyteroi in the early Church"? ${ }^{4}$ Scholarly consensus will remain elusive, according to Kevin Giles, "partly because New Testament comments about presbyters are infrequent and cursory." That, of course, is the case with all discussions regarding the origins and nature of ministry. However, B. W. Powers points out that "the prime calling of the first Christian elders, the apostles" is defined in Acts 6:4 where they give themselves to "prayer and the ministry of the word." 6

\footnotetext{
${ }^{1}$ Bartlett, 127.

${ }^{2}$ Giles, 8 .

${ }^{3}$ Schweizer, 85 .
}

${ }^{4}$ Joseph F. Kelley, The Concise Dictionary of Early Christianity (Collegeville, MN: Liturgical Press, 1992), 143.

${ }^{5}$ Giles, 72 .

${ }^{6}$ Powers, 171. 
My contention that the elders are successors to the apostles and that their work includes prayer can be supported by another line of evidence. I believe that the actual accounts of the activities of the elders in the New Testament advance the argument that prayer was an important part of their ministry. A. E. Harvey asks, "What did these elders actually do?" I disagree when he concludes that "the evidence deserts us almost completely." What did the elders do? They prayed. At least this is the case often enough to conclude that prayer was an important function of the New Testament elders.

\section{The Elder-Texts}

We turn now to an examination of the New Testament incidents in which elders are described. Andrewartha provides a comprehensive overview of $\pi \varrho \varepsilon ́ \sigma \beta v \varsigma$ and its derivatives in the New Testament. He points out that not all the occurrences refer to leaders in the early Christian congregations.

Four refer to ancestors or "men of old," nine indicate the literal comparative "older," and twelve designate the four and twenty elders of the heavenly court. Thirty are references to the elders of Israel or the Sanhedrin. Luke used

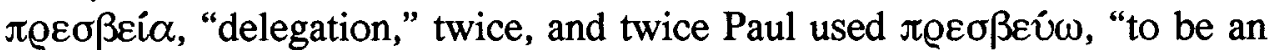
ambassador."2

I want to examine in more detail those occurrences of $\pi \varrho \varepsilon ́ \sigma \beta u ́ \tau \varepsilon \rho \circ$ which refer to leaders in the early Christian congregations. The nineteen such occurrences really comprise only eleven different incidents. Some of the occurrences are references to the same elder, or group of elders. I want to note particularly those
'A. E. Harvey, "Elders," The Journal of Theological Studies, n.s., 25, part 2 (October 1974): 332.

${ }^{2}$ Andrewartha, 30-31. 
occurrences where there is a connection with prayer.

1. Acts 11:30. This is the first verse to mention Christian elders in Acts. When elders initially appear in the New Testament, they do so suddenly and without explanation. The majority of scholarly opinion holds that both the name and the concept had their origin in the Jewish eldership. ${ }^{1}$ Raymond E. Brown says, "It is not unlikely that Jewish Christians of Jerusalem took over the idea of presbyters from the Jewish synagogue." ${ }^{2}$ Of great interest to me is the comment by Thurston regarding the highly developed "ministry of word and prayer" in the Jewish synagogue. ${ }^{3}$ There appears to be a prior connection between elders and prayer in Jewish worship.

Our introduction to the elders of the Jerusalem church occurs when members of the church in Antioch send "their gift to the elders by Barnabas and Saul" (vs. 30) for famine-relief. Ernst Haenchen says, "It is curious that the elders should be thus abruptly thrust forward, and not a word be said of the Apostles." ${ }^{4}$ We are left to guess why? What function did the elders perform that made them the intermediaries in the distribution of this aid? Haenchen offers the possibility that the elders were included among the apostles. At a minimum, Luke "presumes that the elders represent a circle of leaders in Judea."

\footnotetext{
${ }^{1}$ See for instance, Ed Glasscock, "The Biblical Concept of Elder," Bibliotheca Sacra 144, no. 573 (January-March 1987): 71.

${ }^{2}$ Raymond E. Brown, "Episkopē and Episkopos: The New Testament Evidence," Theological Studies 41, no. 2 (June 1980): 327.

${ }^{3}$ Thurston, 8.

${ }^{4}$ Ernst Haenchen, The Acts of the Apostles, trans. from the 14th German ed. (1965) by Bernard Noble and Gerald Shinn, translation updated and rev. by R. McL. Wilson (Philadelphia: Westminster Press, 1971), 375.

${ }^{5}$ Bartlett, 130.
} 
2. Acts 14:23. The second mention of elders is in connection with their appointment as spiritual leaders in the churches of Lystra, Iconium, and Antioch. Luke tells us that "Paul and Barnabas appointed elders for them in each church and, with prayer and fasting, committed them to the Lord in whom they had put their trust" (vs. 23). This incident which occurs during Paul's first missionary journey is the first record we have of elders being appointed in Christian churches. It should be noted that these elders were commissioned to their roles of leadership by means of prayer.

3. Acts 15, 16. Elders are next mentioned in Acts 15 and 16 in connection with the apostles. The two groups appear together and act in concert. Jospeh B. Tyson says, "Here we read that apostles and elders (presbyteroi) exercise authority jointly." ${ }^{\prime 1}$ There is a total of six such references (Acts 15:2, 4, 6, 22, 23; 16:4). Collectively "the apostles and elders" serve as a council which arbitrates a matter of great importance to the developing church. This incident shows that the elders were closely associated with the apostles in making major decisions in the church. In fact, commentators see in this incident "a transitional period when the Jerusalem church turned to the elders rather than to the apostles for authority." 2 With Acts 15 the elders succeed the apostles.

4. Acts 20:17-38. In the next passage to be considered, Paul prayed with the elders of the church at Ephesus. He was returning from his third missionary trip and was on his final journey to Jerusalem when he "sent to Ephesus for the elders of the

\footnotetext{
${ }^{1}$ Joseph B. Tyson, "The Emerging Church and the Problem of Authority in Acts," Interpretation 42, no. 2 (April 1988): 140.

${ }^{2}$ Ibid., 128.
} 
church" (vs. 17). In his farewell to the Ephesian elders, Paul admonishes them, "Guard yourselves and all the flock of which the Holy Spirit has made you overseers. Be shepherds of the church of God" (vs. 28). Paul is here passing on the apostolic mission to the elders of Ephesus.

Andrewartha points out that this incident provides us with "significant information about the Christian elder." It is one of only a few places in the New Testament where we find any explicit information regarding what the elder is to do. ${ }^{2}$ Here Paul describes the appropriate role of elders. As important as this information is, I believe it is equally important for us to observe what the elders actually did.

At the conclusion of Paul's remarks, "he knelt down with all of them and prayed" (vs. 36). Evald Lövestam says, "In Luke's account the presbyters from Ephesus have a clearly representative function. In his speech to them, Paul, at the same time, addresses those responsible for the leadership of all 'his' congregations." In the same way I believe that Paul's actions are intended to be representative. When Paul prayed with the Ephesian elders at Miletus, he was modelling behavior that should characterize the ministry of elders in all "his" congregations. Here "Paul instructs the presbyters of Ephesus to carry on the same ministry which he had exercised among them."4 This is another circumstance in which prayer figures

\footnotetext{
${ }^{1}$ Andrewartha, 37.
}

${ }^{2}$ Other passages which provide a description of the elder's role are: 1 Tim 5:17-19; Titus 1:59; Jas 5:14 and 1 Pet 5:1-4. Although 1 Tim 3:1-7 makes no mention of elders, the qualifications of the bishop, or overseer, listed there parallel those of the elder given in Titus 1:5-9.

${ }^{3}$ Evald Lövestam, "Paul's Address at Miletus," Studia Theologica 41, no. 1 (1987): 1.

${ }^{4}$ Forestell, 113. 
prominently as part of the elders' activities. It is one of the things that they did.

5. Acts 21:18. The last mention of elders by Luke comes in connection with Paul's final arrival in Jerusalem. He "went to see James, and all the elders were present" (vs. 18). That no mention is made of the apostles raises the question of whether their leadership had been taken over by the elders.

6. 1 Tim 4:14. The first reference to elders in the pastoral epistles is to "the body of elders" who laid their hands on Timothy. Paul instructs Timothy, "Do not neglect your gift, which was given you through a prophetic message when the body of elders laid their hands on you" (vs. 14). Although there is no explicit connection to prayer here, one may be implied considering the pattern whereby prayer accompanies ordination.

7. 1 Tim $5: 17,19$. This reference by Paul to elders is of a general nature. He says, "The elders who direct the affairs of the church well are worthy of double honor, especially those whose work is preaching and teaching" (vs. 17). And he advises, "Do not entertain an accusation against an elder unless it is brought by two or three witnesses" (vs. 19). Vs. 17 has provided occasion for considerable debate regarding the number of classes of elders and their functions. However we find no explicit reference to prayer in this passage either.

8. Titus $1: 5,6$. The final reference to elders in the pastorals is found in Titus 1. Paul tells Titus, "The reason I left you in Crete was that you might straighten out what was left unfinished and appoint elders in every town, as I directed you. An elder must be blameless, the husband of but one wife, a man whose children believe and are not open to the charge of being wild and disobedient" 
(vss. 5, 6). Paul's list of qualifications for the elder describes what kind of person the elder is, but not what work the elder is to do or does. Again there is no mention of prayer in this context.

9. Jas 5:14. The single most important reference for this investigation of elders is undoubtedly the one in which James asks, "Is any one of you sick? He should call the elders of the church to pray over him and anoint him with oil in the name of the Lord" (Jas 5:14). Alexander Ross says, "We have here a remarkably interesting glimpse, though it be only a fleeting glimpse of First Century congregational life." Here we are provided an opportunity to observe the elders engaged in their work. What did they do?

It is perfectly clear that those who occupy the office of elder are regarded as the spiritual leaders in the community. These elders are expected to exercise pastoral functions including prayer for healing. Daniel R. Hayden points out that

their very function as spiritually mature persons is not only to give leadership to the church but also to support the saints in their spiritual struggles through instruction and encouragement. James tells the "weak" to call for the strong ("elders") that they may be strengthened through a spiritual ministry of prayer. ${ }^{2}$

D. Edmond Hiebert observes that prayer is "the central feature of their ministry."

We can note that as part of their pastoral care the elders prayed. James understands prayer to be part of the work of the elders.

${ }^{1}$ Alexander Ross, The Epistles of James and John (Grand Rapids: Wm. B. Eerdmans Publishing Company, 1954), 98.

${ }^{2}$ Daniel R. Hayden, "Calling the Elders to Pray," Bibliotheca Sacra 138, no. 551 (JulySeptember 1981): 262.

${ }^{3}$ D. Edmond Hiebert, The Epistle of James: Tests of a Living Faith (Chicago: Moody Press, 1979), 320. 
10. 1 Pet $5: 1$. The next passage referring to elders is in 1 Pet 5 . When appealing "to the elders among you," Peter describes himself "as a fellow elder" (1 Pet 5:1). According to Kistemaker, Peter "indicates that an apostle can also be an elder." Peter's claim to be "a fellow elder" can be understood to mean that "though much broader, the apostolic office included the work of the elders." 2 Peter's designation of himself as "fellow elder" is most often understood to reflect the position that 'an 'apostle' is in some sense an 'elder' to the entire Christian community in the world, not to one church in particular."

In his appeal for the elders to "be shepherds of God's flock that is under your care" Peter ties their service to that of "the Chief Shepherd" (1 Pet 5:2, 4). In this connection I want to note again that Christ's ministry, including His abundant prayer life, is the model for all ministry-that of the apostles, elders, and modern ministers. ${ }^{4}$ Thurston says, prayer "is the manner by which the power that empowered Jesus was transmitted to his followers."

11. 2 John $1 ; 3$ John 1 . These are the last references to elders who were leaders in the early Christian congregations. Both the epistles of 2 and 3 John come

${ }^{1}$ Simon J. Kistemaker, New Testament Commentary: Exposition of the Epistles of Peter and of the Epistle of Jude (Grand Rapids: Baker Book House, 1987), 188.

${ }^{2}$ D. Edmond Hiebert, First Peter (Chicago: Moody Press, 1984), 282.

${ }^{3} J$. Ramsey Michaels, 1 Peter, Word Biblical Commentary, vol. 49 (Waco, TX: Word Books, Publisher, 1988), 280.

${ }^{4}$ In Charles E. Hoekstra's study, "An Examination of the Prayer Life of Jesus to Ascertain the Relation of Prayer to the Pastor's Work" (D.Min. diss., Covenant Theological Seminary, 1987), he begins by saying, "The supreme example of the pastor's need for prayer is . . the Lord Jesus Christ," i. Hoekstra's conclusion is that "the calling of the pastor is the call to prayer," 100.

${ }^{5}$ Thurston, 56. 
from one designated "The Elder" (2 John 1; 3 John 1). Stephen S. Smalley

diplomatically says "The meaning of 'presbyter' here is not immediately clear."

Whether "The Elder" should be understood as an official title, or as an affectionate reference to the "old man" in this instance is disputed.

A further matter of dispute is the identity of the author of these brief epistles. He simply calls himself "The Elder." ${ }^{2}$ By tradition he is John the apostle. D. Moody Smith says, "From the late second century onward, this John is taken to be the disciple of Jesus, the son of Zebedee and brother of James, who also wrote the Fourth Gospel and the Book of Revelation." 3 But, Smith adds, "if that were the case, it seems odd that he should refer to himself as an elder rather than an apostle."4 John R. W. Stott counters, "there is nothing strange about an apostle calling himself an 'elder'.... The apostle Peter used the title of himself, calling himself a 'fellowelder' of those he was addressing in his letter (1 Pet. 5:1)." Stott believes the evidence supports the traditional position that "The Elder" was the apostle John. While we may not be able to establish without doubt that the apostle John was the

\footnotetext{
${ }^{1}$ Stephen S. Smalley, 1,2, 3 John, Word Biblical Commentary, vol. 51 (Waco, TX: Word Books, Publisher, 1984), 317.

${ }^{2} \mathrm{Judith}$ Lieu speaks of "the vexed problem of the address" when she writes that "the way in which the author names himself has yet to find a satisfactory explanation. . . Our problem lies in the variety of ways the term 'Elder' could be used . . none quite fits 2 and 3 John." Judith Lieu, The Second and Third Epistles of John: History and Background, ed. John Riches (Edinburgh: T. and T. Clark, 1986), 52.

${ }^{3}$ D. Moody Smith, First, Second, and Third John, Interpretation: A Bible Commentary for Teaching and Preaching (Louisville: John Knox Press, 1991), 15.

${ }^{4}$ Ibid., 139.

${ }^{5}$ John R. W. Stott, The Letters of John: An Introduction and Commentary, Tyndale New Testament Commentaries, rev. ed. (Leicester, England: Inter-Varsity Press, 1988; Grand Rapids: William B. Eerdmans Publishing Company, 1988), 43.
} 
author of 2 and $3 \mathrm{John}, \mathrm{I}$ am convinced that this conclusion remains plausible.

If it was the apostle John who wrote, "Dear friend, I pray that you may enjoy good health and that all may go well with you, even as your soul is getting along well," (3 John 2) then this is an especially important piece of evidence for our study. Here we find John, who is both an apostle and an elder, praying. And John was no ordinary elder or apostle. Stott says:

There were other elders in Ephesus, but he was unique among them because he was an apostle as well, and a veritable patriarch in age. It is even conceivable that the later technical use of the title 'elders' for 'disciples of the apostles' was derived from John, who as the last surviving apostle and 'the elder' was the link between the apostolic and the sub-apostolic periods. ${ }^{1}$

The prayer for Gaius's good health with which the letter begins follows a conventional form found regularly in contemporary non-biblical letters. ${ }^{2}$ Hiebert acknowledges this but says "the elder's statement makes it obvious that his prayer for Gaius is vastly more than the conventional health-wish for the reader." ${ }^{3}$ John takes seriously his function as an elder to pray for his friend Gaius. Again we see evidence that the ministry of the elders included prayer.

12. Rev 5:8. All twelve occurrences of elder in the book of Revelation refer to the twenty-four elders of the heavenly court. Although they are not leaders of local congregations, it is likely that in some way they are intended to represent those who are. When John describes the scene in the heavenly throne room, he says the

${ }^{1}$ Ibid., 44.

${ }^{2}$ Judith Lieu, The Theology of the Johannine Epistles, New Testament Theology (Cambridge: Cambridge University Press, 1991), 2.

${ }^{3}$ D. Edmond Hiebert, “An Exposition of 3 John 1-4," Bibliotheca Sacra 144, no. 573 (January-March 1987): 60. 
twenty-four elders "were holding golden bowls full of incense, which are the prayers of the saints" (Rev 5:8).

Who are these twenty-four elders? A variety of theories is held regarding their identity, but there is no scholarly consensus. ${ }^{1}$ L. W. Hurtado makes an observation that is suggestive when he says,

The well-established usage of the term 'elder' to describe the leaders in the synagogues and churches of the late first century (if not earlier) seems to give us the most immediate association of the term for the first readers. That is, it does not seem difficult to think that the readers would have found the reference to heavenly 'elders' immediately meaningful on the basis of their familiarity with Jewish and Christian traditions, and would easily have taken these elders as playing a role in heaven similar to that of the earthly elders of Jewish and Christian groups. ${ }^{2}$

The twenty-four elders appear to be performing priestly service in heaven on behalf of the church still below. According to Hurtado, "They are heavenly archetypes, which serve as counterparts and representatives of the earthly saints, offering the prayers of the saints to God directly in heaven." ${ }^{3}$ They function as intermediaries presenting "the prayers of the saints" to God in golden bowls.

Speaking of the adoration directed to God and the Lamb by those who surround the heavenly throne in Rev 4 and 5, Hurtado notes that it "is intended both to stimulate and to give substance to the corresponding worship by the elect upon the

${ }^{1}$ Russell Scott Morton identifies "three possible backgrounds of tradition for John's description of the twenty-four elders: (1) descriptions of heavenly (astrological) figures; (2) the conventions of OT and Jewish apocalypticism ... (3) the twenty-four elders represent concerns of the early church and were meant to portray the unity of the Old Covenant and the New." Russell Scott Morton, "A History of Religions Analysis of Revelation 4-5" (Th.D. diss., Lutheran School of Theology, 1985), 89.

${ }^{2}$ L. W. Hurtado, "Revelation 4-5 in the Light of Jewish Apocalyptic Analogies," Journal for the Study of the New Testament 25 (October 1985): 113-114.

${ }^{3}$ Ibid., 114. 
earth." I believe the same can be said of the activity of the twenty-four elders in connection with "the prayers of the saints." The significance of this reference in Rev $5: 8$ is that it makes real the ministry of the earthly elders as they pray on behalf of the saints. As such, I believe it is appropriate to include it in this consideration of the texts relevant to the transmission of the apostolic ministry of prayer on to the elders and subsequently to modern ministers.

\section{The Meaning of Prayer}

Jesus was a man of prayer. The apostles prayed. So did the elders. What is meant when we say the first ministers prayed? And why should prayer have first place in their ministry?

Scholars debate the meaning of "prayer" in Acts 6:4 where the Twelve declare we "will give our attention to prayer and the ministry of the word." F. F. Bruce, who believes it was public prayer, says "the church's regular worship is meant.". This is possible according to R. C. H. Lenski who says, "The term $\pi \varrho o \sigma \varepsilon v \chi \eta \dot{\eta}$ is frequently used in this wider sense of worship of which prayer constitutes the prominent part." 3 Others have seen here reference to the regular hours of Jewish prayer. ${ }^{4}$

I question the position which limits the apostles' ministry to public

${ }^{1}$ Ibid., 115 .

${ }^{2} \mathrm{~F}$. F. Bruce, The Acts of the Apostles: The Greek Text with Introduction and Commentary, 3d ed. (Grand Rapids: Wm. B. Eerdmans Publishing Company; Leicester, England: Apollos, 1990), 183.

${ }^{3}$ R. C. H. Lenski, Interpretations of the Acts of the Apostles (Columbus, OH: Wartburg Press, 1944), 245.

${ }^{4}$ P. T. O'Brien, “Prayer in Luke-Acts,” Tyndale Bulletin 24 (1973): 122. 
proclamation and public prayer. Manford George Gutzke reminds us, "prayer is much more than just saying prayers." The same Greek word for prayer ( found in Acts 6:4 is used in each of the elder-texts where prayer is mentioned. When Paul and Barnabas appointed elders in Lystra, Iconium, and Antioch, they prayed (Acts 14:23). Their prayer was more likely part of a public ceremony than a public worship service itself. The incident in Miletus where Paul prayed with the Ephesian elders is another example of where prayer may have been part of a public service, but the term does not refer to a public worship service. The same is true of the occurrence in Jam 5:14 where James advises those sick to "call the elders of the church to pray." He means they should engage in intercession for the sick individual rather than hold a public worship service. John's statement that he prays for his friend Gaius (3 John 2) is also a reference to his private ministry of intercession.

Based on the use of $\pi \varrho \circ \sigma \varepsilon v \chi \eta$ in the elder-texts that refer to prayer, I believe that when the Twelve said they were going to give their attention to prayer they meant more than public worship. They understood "that a special responsibility of their leadership is to have time for prayer." ${ }^{2}$ As Everett F. Harrison points out, "This was a time-consuming exercise and one which was indispensable to effective ministry." ${ }^{3}$ The Twelve were going to give themselves first to a private ministry of prayer.

My understanding that the prayer the Twelve committed themselves to was 1966), 74.

${ }^{1}$ Manford George Gutzke, Plain Talk on Acts (Grand Rapids: Zondervan Publishing House,

${ }^{2}$ Thurston, 29.

${ }^{3}$ Everett F. Harrison, Acts: The Expanding Church (Chicago: Moody Press, 1975), 106. 
primarily a private, and not a public, ministry is consistent with the sequence we observe in Acts 6:4 where prayer precedes the "ministry of the word." James M. Campbell said it comes first "because it is the one part of the spiritual ministry of the church which is most apt to be neglected."1 Even more significant is this comment from A. C. Gaebelein:

There can be no effectual ministry, no effectual preaching of the Gospel and Bible teaching unless it is preceded by prayer. Prayer is the expression of dependence upon God. Ministry of the Word must be in utter dependence on the Lord and therefore prayer is the right preparation for it. ${ }^{2}$

The common denominator in all these different prayers is their expression of dependence upon God and confidence in Him over against self. If the priority given to prayer in the work of the New Testament minister means anything, it means that he must deal first with God and only then with the world. The significance is plain: ministry begins in prayer.

\section{Summary}

My examination of the elder-texts and their connection with prayer is complete. Has my attempt to bring together such diverse scriptural witnesses done justice to the New Testament meaning of ministry? I have assumed a common meaning for presbyter in the New Testament church. In doing so, I am not denying the variety which is evident there. I am only recognizing a common denominator which underlies it.

\footnotetext{
${ }^{1}$ James M. Campbell, The Place of Prayer in the Christian Religion (New York: Methodist Book Concern, 1915), 147.

${ }^{2}$ A. C. Gaebelein, The Acts of the Apostles: An Exposition (New York: Publication Office "Our Hope," 1912), 120.
} 
In summary:

1. Prayer was integral to New Testament ministry. Once more I cite Bonnie Thurston's observation that "prayer is the prominent characteristic in the spiritual leadership of the early church" (italics mine). ${ }^{1}$

2. Prayer was central to the ministry of the apostles. Jerome D. Quinn says, When the Twelve describe their duties as they prepare to share them, they declare, "But we will devote ourselves to prayer (he proseuchē) and to the ministry of the word" $(6: 4)$. The first work of the apostolic witness to the resurrection, his first service to the Gospel, is his leadership in the prayer, in the worship, of his fellow believers. ${ }^{2}$

The first organization of the church in which leadership roles are delineated was designed to free the Twelve from everything except prayer and the preaching of the Word. Prayer was their first priority. William H. Willimon says, "In an activist age one might expect the disciples to undertake some more 'useful' activity. They are told to be witnesses 'to the ends of the earth' $(1: 8)$, and their first response is prayer. The action demanded of the church is more than busyness and strenuous human effort."3

3. Prayer was a defining characteristic of the ministry of the elders. Later, this apostolic ministry characterized by the expression "prayer and the ministry of the word" (Acts 6:4) would be held by elders. As successors to the apostles, the main qualification for the elders who tended to the spiritual needs of the church was spiritual competence. Specifically this included prayer. In four of the eleven

\footnotetext{
${ }^{1}$ Thurston, 56.

${ }^{2}$ Quinn, 487-488.

${ }^{3}$ Willimon, 21 .
} 
instances where we find Christian elders in the New Testament, they are involved in prayer. The reference in Rev 5:8 gives significance to this pattern by connecting the prayers of these elders with those of the twenty-four heavenly elders. The elders are ex officio leaders of prayer in the Church. The spiritual functions of the elders are clearly related to preserving continuity with the ministry of the Twelve and of Christ.

I have asked: What part did prayer play in the apostles' work which was assumed by the elders and which has been passed on to today's pastors? The answer is a very significant part. The role of prayer in the work of the New Testament minister is best understood by examining the passages that have just been interpreted. In them we have seen how apostolic ministry is linked through the elders to the church of our own time. Our understanding of what their ministry was is best expressed in what they did preeminently, and that is to pray. From the New Testament emerges a pastoral theology grounded in prayer. What we see is a picture in which prayer was, and is, central to the work of the pastor. 


\section{CHAPTER III}

\section{PASTORS AT WORK: LET THEM PRAY}

Throughout the history of the church, prayer has been an essential part of the work of pastoral ministry. Prayer was an important element of Jesus' ministry. It was central to the ministry of the apostles. The same has been true for the elders who followed them-both ancient and modern. The prominence once given prayer has changed, however, and for the most part, today's busy practitioners of ministry give prayer a lower priority than their ecclesiastical predecessors once did.

Exceptions to this trend exist. My survey of the literature of pastoral theology revealed that some authors lament the erosion of the historic role given to prayer in the ministry. Eugene H. Peterson is one who does. He says,

For the majority of the Christian centuries most pastors have been convinced that prayer is the central and essential act for maintaining the essential shape of the ministry to which they were ordained.

Why is this century of pastors not voting with the majority? Have conditions changed so much in our age that prayer is no longer fit to be the formative act? Have developments in theology shown other things to be central and prayer at the periphery? Or have we let ourselves be distracted, diverted, and seduced? I think we have. ${ }^{1}$

Another writer who thinks that pastors have let themselves be "distracted, diverted, and seduced" from the traditional concept of the minister as a person of

'Eugene H. Peterson, Working the Angles: The Shape of Pastoral Integrity (Grand Rapids: William B. Eerdmans Publishing Company, 1987), 19. 
prayer is Eugene Bradford. His article, "Intercessory Prayer: A Ministerial Task," shows where the thinking of the church once was. Bradford points out that the Form of Church Government adopted by the Westminster Assembly in 1645 listed eight duties which belong to the office of pastors. Significantly, the first of these mentioned was prayer.

First, it belongs to his office, to pray for and with his flock, as the mouth of the people unto God, Acts vi.2, 3, 4 and xx.36, where preaching and prayer are joined as several parts of the same office. The office of the elder (that is, the pastor) is to pray for the sick, even in private, to which a blessing is especially promised; much more therefore ought he to perform this in the public execution of his office, as a part thereof. ${ }^{1}$

Because this element of ministerial duty does not receive the same emphasis

today, Bradford goes on to call regrettable

the almost total lack of attention to the subject of the minister's prayers in current discussion of the sacred office. Books and articles are written on the techniques of preaching, church administration, and counselling, but the banal comments on the pastoral activity in prayer serve only to point up how little importance is generally attached to this function. ${ }^{2}$

Confirmation for Bradford's concern comes in a 1984 Christianity Today article entitled, "How Many Hats Does Your Pastor Wear?" by Rodney Clapp. Coincidentally, Clapp also identifies eight primary functions of the minister. They are: "administration, education, speaking, statesmanship, music ministry, spiritual direction, evangelism, and counseling." ${ }^{3}$ Where is prayer? Subsumed under other ministerial functions? Or, worse yet, displaced by pastoral roles never heard of until

\footnotetext{
${ }^{1}$ Westminister Assembly, quoted in Eugene Bradford, "Intercessory Prayer: A Ministerial Task," The Westminster Theological Journal 22, no. 1 (November 1959): 13.

${ }^{2}$ Ibid., 14.

${ }^{3}$ Rodney Clapp, “How Many Hats Does Your Pastor Wear?” Christianity Today, 3 February
} 1984, 24. 
recently such as "statesmanship" or "music ministry"?"

One other author who witnesses to what once was is James N. McCutcheon. He says that "from the beginning, it has been a particular duty of parish ministers to pray."2 McCutcheon began his book, The Pastoral Ministry, with a chapter entitled, “The Parish Minister's Professional Devotional Life." In it he writes, "a private professional devotional life, modeled on the practice of Jesus and celebrated by monks, order priests, and parish clergy through most of the Christian centuries, remains the essential foundation of the parish ministry today."3

Believing that "the largest number of parish ministers not only no longer pray daily for their parishioners; of even greater moment, they no longer seek divine guidance and strength for themselves,"4 McCutcheon goes so far as to conclude that the minister's identity crisis results from this absence of "a private professional devotional life." For him, "one of the chief reasons so many Christian clergymen are today leaving the parish ministry for other fields is rooted in a prior failure to establish and maintain, after the manner of Jesus and the example of earlier centuries, a serious professional devotional life."

Could there be a cause and effect relationship between pastors leaving the

${ }^{1}$ Clapp cites Richard Foster's definition of spiritual direction as being distinct from pastoral counseling, saying, "Spiritual direction does not have this crisis element: it is offering direction on a continuing journey, a growth in the spiritual disciplines of prayer, study, and a giving life." Ibid., 26. I believe that if we treat prayer as only one of the spiritual disciplines and make it equal to others such as simplicity, solitude, submission, and service we dangerously downplay its importance.

${ }^{2}$ James N. McCutcheon, The Pastoral Ministry (Nashville: Abingdon, 1978), 20.

${ }^{3}$ Ibid., 11.

${ }^{4}$ Ibid., 14.

${ }^{5}$ Ibid., 12. 
ministry and their failure to pray? I know of no confirming evidence for McCutcheon's contention; however, the mere fact that he has intimated as much should be of great concern to all who have an interest in the future of ministry.

What is being said is that there was a time when a discussion of the place of prayer in the work of the pastor would have occurred to no one, for prayer was classically defined as the very essence of ministry. Times have changed though, and such a conversation is very apropos today. It was just such a conversation that I set out to have with five of my ministerial colleagues. Their stories constitute the focus of this study. In listening to them tell what they believe about prayer and how they practice it, I have attempted to discover the extent to which they, as pastors, understand prayer to be part of their work. How did they learn to pray? How do they pray as pastors? How do they understand prayer? What are the barriers which keep pastors from their work of prayer? How do they feel about their personal prayer lives?

\section{A Qualitative Approach}

I have used qualitative research for the study reported in this chapter because I believe it has the greatest potential for dealing with the subject under discussion. In writing this as a pastor, I recognize that I am part of the study, a participantobserver, if you please. In any research the perspective of the investigator is reflected in his work. This reality is recognized to a greater extent in qualitative inquiry. In a very personal way, I share in the feelings and meanings surrounding the issues that are explored. As a Seventh-day Adventist minister for twenty-one years, I am very invested in this project and admit that it is more than an attempt to 
understand the perspective of other pastors. Admittedly, it is an effort to understand my own ministry.

Overall, the research addressing the question of prayer as a part of the pastor's work is sparse. The majority of it is prescriptive, that is, it approaches the subject "from the top down." It prescribes what should be, rather than seeks to understand what is, in the lives of pastors. Those studies which are more descriptive, in that they seek to reflect what is, unfortunately provide only quantifications of the pastor's prayer activities. The question, "How much time do you spend in prayer?" cannot be our only query if we are going to understand the pastor's perspective on this matter. There appears to be very little research in the literature of pastoral theology that attempts to reflect the practicing pastor's understanding of prayer as it relates to his or her work. This project report is an attempt to fill part of that gap. I interviewed five active parish pastors for this study. One is an Episcopal priest, another is a pastor serving the Reformed Church in America, two are Seventhday Adventists, and the fifth is a United Methodist. I make no claim that the five pastors interviewed are representative of anything more than my personal friends. The pastors chosen for this study are a "purposive sample." ${ }^{1}$ My selections were based on two subjective criteria which I hoped would facilitate the interview process. I chose pastors with whom I was friends prior to the interviews to take advantage of the confidence level that already existed between us. Second, I chose pastors whom I believed were comfortable with intentional reflection on their own ministry. This

\footnotetext{
${ }^{1}$ Bruce L. Berg says, "When developing a purposive sample, researchers use their special knowledge or expertise about some group to select subjects who represent this population." Bruce L. Berg, Qualitative Research for the Social Sciences (Boston: Allyn and Bacon, 1989), 110.
} 
too was a quality I needed to build on in my interviews.

I conducted three one-hour interviews with each pastor at intervals of a week or more. A non-standardized format of personal in-depth, open-ended questions was used during the interviews. As part of the interviews, I also asked the pastors for their responses to a collection of cartoons which had to do with prayer as a part of the pastor's work. The cartoons are included as appendix B to this project report. Tape recordings were made of the interviews. I approached the transcripts of those interviews inductively. I immersed myself in them to identify the themes that seemed meaningful to the pastors I interviewed. For the sake of confidentiality, the names used for the pastors in this study are fictional.

The major areas covered in the interviews were: (1) the pastors' personal prayer pilgrimage, (2) their present practice of prayer, (3) their understanding of prayer, and (4) how prayer was a part of their pastoral work.

\section{Learning to Pray}

Each of the five pastors learned to pray as a child at home and in church. They had no formal instruction in prayer. The learning took place by "osmosis, or by being there," as one of them described it. It was of interest to me that three of the pastors I interviewed made some reference to the role pastors had in developing their early prayer lives. For Adam it was a positive experience. His parish priest was the one who taught him the most about prayer. He recalls that, "Since I was a little boy I looked up to him and wanted to be just like him." That was not the case with Ben. He appreciates his minister grandfather because, 
his prayers were a bit different than the ministers I had in my own home church. Those guys in my own home church prayed what I would call formal prayers and they were wonderful, flowery language, beautiful and all the rest of that stuff and they were nothing really cool, to be honest with you. My grandfather did things a bit differently. He wasn't really praying at the drop of a hat all the time, but his was a much more conversational type of prayer.

Dan grew up in a small church where the stilted prayers of the pastors contrasted with the simple ones he heard his father pray. He remembers that when his mother was seriously injured, his "father just gathered us around and he prayed a very simple prayer. It was just talking to God like God was right there. . . . I began praying just like my father did, just openly, briefly and to the point-no fancy introduction."

Over two decades ago, in 1970, the Final Report of The Lilly Endowment Project on the Deepening of the Spiritual Life of the Seminary Faculty reported the concern of the Lilly Endowment staff over the number of clergymen who were leaving the ministry. They wondered,

Why was it that these clergymen did not have sufficient spiritual strength and stamina to meet and carry the heavy strain of the ministry without becoming depleted, exhausted, and frustrated? Surely all the spiritual resources of God in Christ and the Holy Spirit were available to these clergy. What was lacking in the training given these men in the theological seminaries, that was producing these results? ${ }^{1}$

The project's director, Charles F. Whiston, discovered that "there was notably absent any serious attempt to teach, train and discipline the theological students in the life of prayer." ${ }^{2}$ In the Final Report, Whiston went on to say what I believe is of crucial importance.

${ }^{1}$ Charles F. Whiston, The Lilly Endowment Project on the Deepening of the Spiritual Life of the Seminary Faculty (N.p.: Final Report, December 1970), 3.

${ }^{2}$ Ibid. 
Many students expressed the hope and expectation that they had in coming to the theological school that there at last they would be offered both instruction in prayer and help and direction in the practice of it. This they expected would be an integral part of their preparation for the Christian ministry. ${ }^{1}$

Mennonite pastor, Arthur P. Boers, said in his article, "The Pastor's Life of Prayer," in The Christian Ministry, things are changing but,

I have degrees from two seminaries and have studied at a third, but I received little training in prayer. I learned how to read scriptures, counsel people, reach out to the neighborhood, organize communities, mediate conflicts, administer a church, run meetings, deploy volunteers and practice theology (even in revolutionary situations!) but not how to pray. ${ }^{2}$

I asked my pastor friends about the training in prayer they received as part of their theological education. Neither of the Seventh-day Adventist pastors, Carl and Dan, had any. Eugene, the United Methodist pastor could not recall any either.

Their experience contrasted sharply with that of Adam, the Episcopal priest, who was required to attend both Morning Prayer and Evening Prayer as well as Eucharist every day while in seminary. It was a formative experience for him. It said to him, "My day does begin with prayer. My day does end with prayer. It's a structure around which my day lives." Ben, the Reformed pastor, took two courses in seminary on prayer. One, he felt, was a waste; the other was more useful, but not all that he had hoped for. His concession that maybe prayer "is hard to teach" could be a partial explanation of the failure of some seminaries to even attempt to do so.

However, the stories that unfolded from my interviews suggest a need for intentional training in prayer as part of pastors' theological education.

'Ibid., 7.

${ }^{2}$ Arthur P. Boers, "The Pastor's Life of Prayer," The Christian Ministry 25, no. 2 (MarchApril 1994): 10. 
All of the pastors I interviewed approach their personal prayer lives very differently. Dan began his ministry feeling that praying was something he had to do well as a minister; however, he did not know how to pray the fancy prayers he heard other ministers pray. He says,

I battled with prayer, that is public prayer, until finally one day I realized that I was not praying to men, I was praying to God and I decided not to worry about what I was going to say, just say whatever I had in my heart and I still pray that way, and I still am bothered by some of the speeches I hear people make when they pray.

Reading Henri J. M. Nouwen's book, With Open Hands, resolved some of Dan's struggles with prayer. Nouwen's statement, "To pray is to live," produced a revolution in Dan's praying. He says, "It freed me from the feeling that praying is a set time, a set place, a set way of speaking."

Dan recalls that when he tried to pray in a structured way, it was a failure. He says, "I don't have an hour in the morning when I pray or an hour in the evening when I pray. I talk to God very casually and comfortably any time during the day or night." On the other hand, Adam, the Episcopal priest, indicates that he finds such routine enabling for him. He schedules time first thing in the morning for prayer and would also like to have a regular time of evening prayer just like during his seminary days. Throughout the day Adam tries to live in the presence of God with his people on his heart, as Michael Ramsey has defined prayer. Eugene's approach to prayer lies between that of Dan and Adam. Having been taught that you should always be in an attitude of prayer, Eugene says, "I pray continuously."

\section{Two Disturbing Themes}

In analyzing the transcripts of the interviews I conducted with my five pastor 
friends, I have identified two major themes. Both of them were disturbing. The first, and perhaps most significant, is the feeling of guilt associated with their prayer lives. The second theme which kept surfacing in our conversations was the tension between being and doing that is part of their ministry.

\section{Feeling Guilty About Prayer}

In the preface to his book, Liberating the Leader's Prayer Life, Terry Muck says, "I quickly learned Christian leaders love prayer; I also found they carry a certain amount of guilt about not praying enough or not doing it well."1 My findings confirm Muck's conclusion. In fact, it is guilt about praying that is the most prominent theme in the interviews I conducted for this project.

In his book, Spiritual Leadership, J. Oswald Sanders quotes Dean C. J. Vaughan as having once said: "If I wished to humble anyone, I should question him about his prayers. I know nothing to compare with this topic for its sorrowful selfconfessions." $^{2}$ It was not my wish to humble anyone. In asking my pastor friends about their prayers I did, however, hear their "sorrowful self-confessions." What I heard from them was not unlike the confession Ronald W. Goetsch makes in an article he wrote entitled, “The Pastor's Devotional Prayer Life." Goetsch writes,

When I read or hear of the experience and practice of others, I am deeply shamed. There are experiences of which some people write that are quite beyond me: regularly spending hour upon hour in prayer. Who has not heard of the pithy saying of Luther, "Fleiszig gebeten ist ueber die Haelfte getan" ("Diligent prayer is over half of the work"), and of his extraordinary assertion that he habitually spent three hours a day in prayer? As far as I am concerned, even an

'Terry Muck, Liberating the Leader's Prayer Life, vol. 2, The Leadership Library (Carol Stream, IL: Christianity Today, 1985; Waco, TX: Word Books, 1985), 9.

2J. Oswald Sanders, Spiritual Leadership (Chicago: Moody Press, 1967), 75. 
hour spent in intensive prayer would be, I am afraid, the next thing to an utter impossibility. And I am bold enough to believe that I am not alone in my embarrassment. Wonder of wonders, even Luther finds himself embarrassed! He writes of his own experience, "At times I, who teach this and prescribe it to others, have learned from my own example that praying comes close to being the most difficult of all works. Therefore I do not claim to be a master in this task."

One source of the pastors' guilt is identified by Goetsch. It is the intimidating standard set by past spiritual giants like Martin Luther and E. M. Bounds.

When I questioned him about his praying, Ben confessed, "I feel guilty that my personal prayer life is not the hour or two hour a day prayer life of Luther." Carl also felt compelled to admit, "I do not have a time when I just get down on my knees for an hour or two and pray. I suppose that's where I feel guilty sometimes because my prayer life isn't like what I read in E. M. Bounds and all those other books on prayer."

\section{Permission to Be Themselves}

Dan, the other Seventh-day Adventist pastor I interviewed, does not care for Bounds' approach to prayer either. He feels that Bounds makes "prayer sound like it is so difficult, so methodical, so scientific." At the same time Dan is willing to acknowledge that other people benefit from more structured approaches to prayer. He believes that prayer is an individual thing and that people "need to find their own style; their own way of conversing with God and listening to God."

It was clear from my interviews that the individual personality of each pastor is reflected in his practice of prayer. They are saying that their prayer life is an

${ }^{1}$ Ronald W. Goetsch, "The Pastor's Devotional Prayer Life," Concordia Journal 12, no. 6 (November 1986): 217. 
expression of who they are. In a sense they are asking permission to be themselves and not some much revered "prayer warrior" from the past. This same idea is articulated by Chuck Killian, professor of preaching and drama at Asbury Theological Seminary, in an interview. He says, "My desire is not to be another Praying Hyde or Martin Luther. I simply want to make a good Chuck Killian.

That's all God is asking of me."1 The pastors I interviewed feel guilty because they are not sure they have permission to be themselves when it comes to their praying.

This dilemma is most apparent in my interviews with Carl. Repeatedly he told me, "My prayer life is very individual. I don't fit the mold." He says, prayer

is a very private thing between God and me and very informal. It's not something that I do well publicly. I do a lot of talking to the Lord while I drive and when I'm by myself. When I jog, I spend time talking to the Lord. When I'm riding my bike I talk to the Lord just like I do you. Prayer is as vital to me as breathing because I do it the same way. I pray as I breathe, I pray as I walk, I pray as I talk.

Because Carl's prayer life is interspersed among all the other things he does, and he does not follow a more formal routine in praying, he questions whether his is "really bona fide praying."

Someone should tell Carl that he is in the best of company with his individual approach to prayer. John Koenig says,

The distinctive mark of Jesus' own praying . . . is his solitary stance before God. ... Jesus' individuality in God's presence must also be understood as a model for every believer. ... There is something about our praying too that requires intensely personal and private conversations with God. ${ }^{2}$

${ }^{1}$ Charles Killian, "Spiritual Disciplines for the Undisciplined," interview by Bob Moeller, Leadership 14, no. 4 (Fall 1993): 53.

${ }^{2} \mathrm{John}$ Koenig, Rediscovering New Testament Prayer: Boldness and Blessing in the Name of Jesus (San Francisco: Harper, 1992), 17-18. 
Elsewhere Koenig points out that although we pray as individuals "our praying is never solitary; for life in Christ also means being a member of his Body, where mutual supplication for all the saints is the norm." And we can also remember that our petitions are combined with the heavenly intercession of Christ.

\section{Pressured by the Expectations of Others}

Carl's feelings of guilt go beyond just those relating to his prayer life. At the heart of his concern is his perceived failure to meet the expectations others have of him as a pastor. When I asked Carl whether he thought his brand of ministry was legitimate, he answered hesitatingly, "If I didn't have to answer to you or [to my denominational hierarchy] . . . or to my wife or to anybody else, yes." Although greatly respected by both his colleagues and his church members, Carl still feels compelled to measure the success of his ministry by what he believes are their expectations of him.

What bothers Carl about E. M. Bounds is that his book, Power Through Prayer, had been shared with him in a manner which seemed to say, "if you don't follow this prescribed thing, then you are not really being a very good pastor. ... There was not room for a different kind of experience." Carl has tried to pray like he thought others expected him to, but has concluded, "It doesn't work for me. . . . I think that's part of the reason for the guilt. . . . I don't fit the mold that I think many people have of prayer. I sure hope there's room for me." Carl believes that pastors have a real problem with their identity-with just being themselves. He wants to

\footnotetext{
${ }^{1}$ Ibid., 161.
} 
know, "Can I be me? I do have a prayer life." Carl asks that question, not for himself alone, but for many of his fellow pastors who do not have a "one size fits all" prayer life either.

Pastors' perceptions of the expectations others have of them are a significant factor in producing what Joseph Sittler called "vocational guilt." In the Lyman Beecher Lectures on preaching in 1959, he pointed to their "guilt-begetting busyness"1 which he said was a result of the maceration of the minister. The minister's role has been chopped up into small pieces and he or she is held accountable for a myriad of tasks related to being the executive officer of the congregation rather than being "the shepherd of God's flock" that He has placed under their care (1 Pet 5:2).

Eugene's experience illustrates the pressures pastors face to adjust their work according to congregational expectations. He feels his present church would not understand if he took time to pray from the time they think he should be available to them. Eugene says, "Here they like an administrative type. They said they didn't. I have it in writing, but they do. It has always come to that." He continues,

The last church I was in I had to please some of them by telling them all of the calls I made. They wanted me to tell them where I went and all that, but I would not do that. The number of calls I made every week and everything I did had to be written out. When you go to list those things out you don't usually put down, I spent an hour or two in prayer every day or whatever, you know. They would say, "Yeah, yeah."

Eugene acknowledges that it would be hard to wipe out these deeply ingrained congregational expectations. He says, "I don't know how long I would last here," if

\footnotetext{
${ }^{1}$ Joseph Sittler, The Ecology of Faith (Philadelphia: Muhlenberg Press, 1961), 84.
} 
I functioned outside of their expectations.

Eugene's story is characterized by the tension between meeting the expectations of his congregation and living up to his own call to ministry.

Sometimes Eugene dreams of starting ministry all over again. I can understand why he might want to begin his ministry again. His call to ministry was confirmed by an unexpected and dramatic answer to prayer that is reminiscent of the Apostle Paul's famous conversion on the road to Damascus. Here is his story as he related it to me:

Eugene: When I was struggling with my call into the ministry, I was meeting with the pastor at the church. He and I would get together early in the morning and go to the church and make some toast and coffee and then we would have Bible study and prayer. One of those mornings I was praying and asking God to give me some kind of a light. You know, maybe hear a voice say, "Yes," which I never got. I just felt that is what God wanted me to do. I said, "Give me a light," and the room filled with light. It was just a real bright light like the sun, and the sun was not really fully up yet. From that time on, I felt very sure that that was what $\mathrm{He}$ wanted me to do.

KLS: That experience was obviously an impressive one for you. Do you think about it often?

Eugene: Yes, a lot. I think about it when I get tired of all the nitty, picky things.

KLS: It has continued to be a light for you, pointing you toward the direction that you want to go.

Eugene: I have not had a lot of experiences like that. They don't happen to me every day. That was a very powerful thing in my life. If it had been the sun that came in there maybe it would have impressed me-the timing of it, but as I recall now it was just getting light out. I said, "Give me a light," or something like that. Then this light just hurt your eyes when it came in the room.

That is how ministry began for Eugene. His idealism has been dashed, however. Although he began his ministry committed to follow the light that came in answer to his prayer, he now serves a congregation that does not share his understanding of ministry. Sadly, he has conformed the performance of his work to 
their expectations. Referring to his original resolve to make spiritual leadership the focus of his ministry, Eugene says,

I started that way. I hadn't been here very long and I started hearing the complaints and the pressure from the P[astor] P[arish] R[elations] Committee to be here more and take more of an administrative role. I sign all the work orders that come through here. Now I sign all the checks. I have to know everything that goes on here and we have full-time and part-time staff-eight or ten of them-plus all the other things that come in. They want me to be available at all times.

So does God. He, too, wants us to be available at all times. It is precisely at this juncture-the tension we experience between the demands of God and those of our congregations - that as pastors we face our most trying dilemma.

The pressure to perform according to the changing expectations others have of pastors has led to the redefining of their pastoral roles. This can go to the ridiculous extreme portrayed in the Rob Portlock cartoon (see appendix B). Portlock pictures a pastor on his knees in prayer. While beholding a theophany, he is interrupted by the demand that he tend to the crisis of a "broken hand dryer in the ladies' room."

Ben, my Reformed pastor friend, had previously told me that we tend "to put God on hold because we're more accustomed to dealing with the immediate than the imminent." When I showed him the Portlock cartoon he responded by saying,

What a terrible misunderstanding of what a pastor is. I see this all the time in the church. People always say, "What about this thing?" And it's a very concrete, physical thing. Now in our polity, the deacons are taking care of that. That's their responsibility and no matter how often I say it they don't seem to get the message. I say, "Well, talk to the chairman of the deacons about that." Oh, as if that never occurred to them. But they know better.

Ben went on to say, "If you're going to stay in ministry, and be effective in ministry and really be able to do what God has called you to do-not just what the church has called you to do, but what God has called you to do-I think it's an absolute 
necessity to be a man who is in touch with God."

Unfortunately the understanding of prayer as it relates to the work of the pastor portrayed in Portlock's cartoon and confirmed by Ben's experience appears to be very widely held. Dan's response to the same cartoon was as follows:

It expresses confusion about who I am and what I should be doing. It brings back to my memory a recent board meeting in which I told the people that since we built the new church I feel that I have been doing a lot of caretaking and watching over the building . . . and that I was tired of doing that and that I did not see that as my role. One man spoke up and said, "What do think we pay you for? If you don't do it, who is going to look after this place?" That was very graphic proof to me that the congregation expects me to be over there sweeping off the roof and making sure that the bathrooms work properly and they would be happy if I did that. But praying and preparing to lead people spiritually, I don't know.

David N. Mosser warns pastors that "if we do not define our function within the congregation, the congregation will define it for us." ${ }^{1}$ When this is allowed to happen the pastors' commitment to prayer gets squeezed by this pressure and they end up feeling guilty. Henri J. M. Nouwen expresses it this way, "Our demon says: 'We are too busy to pray; we have too many needs to attend to, too many people to respond to, too many wounds to heal. Prayer is a luxury.",2

Dan told me, "I am not going to allow a congregation to put me into their mold." Although Dan is one pastor who does not share the feelings of guilt regarding his prayer life that the other pastors I interviewed expressed about theirs, he understands how spending time in contemplation, meditation, and prayer can produce a lot of guilt for pastors. He said, "They think I should be out visiting Mrs.

${ }^{1}$ David N. Mosser, "Managing the Public Life, Freeing the Personal Life," The Christian Ministry 23, no. 2 (March-April 1992): 11.

${ }^{2}$ Henri J. M. Nouwen, The Living Reminder: Service and Prayer in Memory of Jesus Christ (New York: Seabury Press, 1977), 12. 
Jones, who just had surgery last week. I should be off talking to Jim, who has not been to church in four weeks." What makes Dan feel guilty is the time he is expected to spend keeping track of money and caring for the physical plant of the church. But Dan added, "I don't think that prayer and ministry of the Word involves all that." The Twelve had similar feelings about serving as the equivalent of "bus boys" for the early church. Dan said,

Jesus' life tells me that solitude is really a part of my role as a pastor. That is the way that you draw closer to God. Jesus was in demand, but He would always find time to be alone with His Father. That is where He really learned to submit Himself totally and fully to His Father's will. I think that is a very important part of the pastor's role. I never feel guilty about taking that time. Sometimes I go out to Lake Michigan and just walk when there is not another soul around, and just lift my eyes to the clouds and the sun and the expanse of water and say, "God is good." To me, that is a very important part of my work and I don't feel guilty at all about taking time to do that.

\section{Pressured to Be Productive}

Eugene identified another way in which prayer and guilt come together for the pastor. Because prayer is something you don't have to do, there is a tendency for it to get cut out when pastors get busy. Eugene admitted, "It shouldn't, because you know it should be a real priority." But, "if you put it right into your schedule, you [have to] ... deal with the guilt and the pressure of people saying, 'What are you doing?" Eugene told me, "I have heard of pastors who close the door and are in there in prayer. If you are outside you probably hear criticism. 'Why is the door closed? What is he doing in there? Taking a nap?'”

Dan also feels that pastors are made to feel negligent when they take time to

pray. Donald R. Hands and Wayne L. Fehr, the authors of Spiritual Wholeness for Clergy, refer to "the familiar pattern among clergy of compulsive overwork and a 
'driven' way of ministering." 1 Dan believes pastors "are driven, they are driven to

produce." According to him this is often a reason why pastors do not pray.

I think that is one of the factors that has certainly tugged away at me, and I have talked to other men and women in ministry who feel the same way. I think some of that is produced because we are told to make sure that our hours are productive. We are very much into producing in ministry. I think much of what we do in ministry is intangible. I don't think we can tabulate it on a piece of paper.

Just what are we doing when we pray? Ben Patterson confessed in a

Leadership article, "The Central Work of Prayer," that

prayer is always getting nudged aside, neglected, or perfunctorily performed as more pressing concerns take center stage. Many of us feel we just have too much to $d o$ to have time to pray. That is the problem. At bottom, we don't believe we are really doing anything when we pray, other than pray, that is. ${ }^{2}$

Richard John Neuhaus obviously concurred with Patterson's sentiments when he wrote, "Although few would state it so bluntly, prayer seems to be a distraction from so much that needs doing."3

In his Leadership article, Patterson says, "We must learn that prayer is our chief work. Only then can our work become prayer." ${ }^{4}$ Here Patterson has in mind St. Benedict of Nursia, founder of the Benedictine order in the sixth century whose slogan was "Ora Labora, from the Latin ora, pray; and labora, work. He taught his followers that to pray was to work, and to work was to pray. Following that rule,

${ }^{1}$ Donald R. Hands and Wayne L. Fehr, Spiritual Wholeness for Clergy: A New Psychology of Intimacy with God, Self and Others, with a foreword by Susan Howatch (Washington, DC: Alban Institute, 1993), 55.

${ }^{2}$ Ben Patterson, “The Central Work of Prayer," Leadership 3, no. 1 (Winter 1982): 114.

${ }^{3}$ Richard John Neuhaus, Freedom for Ministry, rev. ed. (Grand Rapids: William B. Eerdmans Publishing Company, 1992), 137.

${ }^{4}$ Patterson, 117. 
the Benedictine order broke down the artificial dichotomy between work and prayer." The Benedictine understanding that to pray is to work, and to work is to pray, is sometimes used as an excuse to work and not to pray. Gerald R. Niklas says many times it is falsely stated that our work is our prayer when what is really meant is that "we haven't time to pray because there is so much work that needs to be done."2

When I asked Eugene why ministers do not pray, he said frankly, "Busyness. Not making it a priority. Maybe not even believing that it is that important, or fooling ourselves into thinking that we are always in an attitude of prayer, so therefore we don't need particular times of prayer." When Eugene elaborated on his response to my question, he identified what must be the most seductive excuse pastors use to keep from praying, i.e., "I am doing the Lord's work." Somehow we are able to rationalize that we are too busy to pray-to talk with God—because we have so much of His work to do.

I pressed the issue of allowing the expectations of others to shape our ministry with each of the pastors by asking what they would do if the telephone rang while they were praying. Eugene was a bit defensive when he said, "Answer the phone probably." Then he laughed, "We're saying God can wait. The telephone is more important." Sometimes it is, but not when it represents the opportunity to talk with God. When I showed Eugene the Doug Hall cartoon (see appendix B) of the pastor who is so swamped by busy work that he does not have time to return God's

${ }^{1}$ Ibid.

${ }^{2}$ Gerald R. Niklas, The Making of a Pastoral Person (New York: Alba House, 1981), 156. 
calls, he said, "That is what I was trying to say. That picture just says it. All of this, and prayer gets cut out." Eugene clearly saw himself in that picture of the poor frustrated pastor.

When I asked Adam about the telephone he said, "It's back to that old thing about company time." Adam had previously related a story about "company time" that poignantly illustrates the pressure pastors face because prayer is not understood to be part of their work. Here is his story:

I was about to be ordained. The seven of us ordinands were meeting with Bishop Montgomery of Chicago. He is certainly a man of great prayer. He was talking about a corporate executive type of person who called the office one morning at nine o'clock and wanted to speak to Bishop Montgomery. The secretary said, "I'm sorry. He's downstairs in the chapel leading morning prayer."

The executive was taken aback and said, "What! On company time?"

It was a great story because it expresses what must be the thought in many. people's minds-if the clergy are spending time praying there's a certain wasted time there, they ought to be doing the other stuff, and prayer ought to be on their own time. Your prayer is on your own time. Your Bible study is on your own time. Your sermon preparation is on your own time. That story reminded me-whose company is this? This is God's company and this is certainly where God wants us to be. Not only should we not be embarrassed by that-we ought to take the time-take it right out of company time and use it that way.

John $\mathrm{R}$. Throop recalls the same great story in a Leadership article on the discipline of prayer. He says the executive's "response isn't surprising. Prayer and work are often viewed as mutually exclusive. But our fundamental work as pastors is prayer. Everything we do takes shape and direction from it."1 This may be true, but the story Adam told about Bishop Montgomery illustrates that prayer must still compete with powerful counterclaims regarding just whose company it really is that we are working for. If, as Adam says, it is God's company, then Dan's confession is

\footnotetext{
${ }^{1}$ John R. Throop, "Practicing the Original Passion," Leadership 14, no. 4 (Fall 1993): 43.
} 
especially tragic. He said, "There are times when I get caught up in what I am doing and I can become very preoccupied and go for a fairly lengthy time without consciously sharing with Him or communicating with Him even in my heart."

Pastors feel guilty about their praying. For us to acknowledge this is not necessarily a bad thing, however. Koenig writes,

Here many of us who are clergy will feel called upon to make embarrassing confessions. Yet our honesty can also be a way toward health. To speak of our deficiencies before God is a prayer of repentance; and Jesus promises that whenever we attempt it, "there is joy before the angels of God" (Lk. 15:10), which means in God's own heart. ${ }^{1}$

\section{Caught in the Tension between Being and Doing}

My five pastor friends personify the age-old debate between being and doing. The tension between these two focuses provides another way for us to see how they understand prayer as part of their work. In the preface to Bede Frost's book The Art of Mental Prayer, Abbot Denys of Nashdom says, "Being and not 'Doing' is the allimportant thing." Neuhaus points out that "a great temptation of ministry is hollow activism. One tries to convince others, and oneself, that one is doing something important because one is always busy." ${ }^{3}$ Keeping our focus on being instead of doing is not easy in our activist age because the pressure on ministers to be doing things pretty well stomps out any thought of simply being in the presence of God.

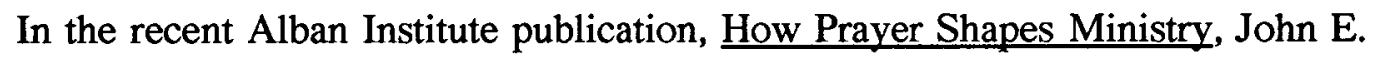

\section{${ }^{1}$ Koenig, 2.}

${ }^{2}$ Abbot Denys of Nashdom, preface to The Art of Mental Prayer by Bede Frost (London: S.P.C.K., 1960), ix.

${ }^{3}$ Neuhaus, 203-204. 
Biersdorf quotes a colleague who, "in a bright moment of frustration and illumination asked, 'How do I do being?" Biersdorf says, "That summarizes the question of prayer in ministry. How do I and any minister in the midst of the varied pressures and activities of our professional lives discern and ground that 'doing' in our being in the presence of God?"1

Biersdorf makes it plain that "the tension or contradiction between the faith grounded in prayer mandated in our calling and the daily pressures of ministry that endanger that fundamental meaning and motivation" are neither new nor easily resolved. Biersdorf continues by saying,

To suggest a quick solution, such as finding time to pray in the morning, is to discount the experience of so many ministers who have personally wrestled with these issues. It is not accidental that we struggle with the contradiction; it is central to our ministry. Prayer is not just a resource for ministry, an add-on to be jettisoned when there is real work to do. ${ }^{2}$

Adam indicated that being and doing need to be integrated in ministry. He spoke of this balance when I asked him what kept ministers from prayer.

We feel we ought to be doing something. . . . Part of the guilt about prayer is that prayer is inactive. So if we're doing that for very long it's like, "What am I doing? Am I supposed to be doing something else?" And there's a great sense of reward from doing more than from being. I accomplished this today, I got this letter out, I wrote my newsletter piece or my sermon or something like that or I visited seven people in the hospital. That's fine up to a point. For me it's integration. If I can integrate the two then I'm headed in the right direction.

Adam said, "I'm Benedictine, if there is such a thing as being Benedictine outside of a monastery." For him that means integrating being and doing. He said,

We wish we could somehow rise above the little stuff and just handle the lofty, but the reality is we're going to have to deal with the fact that we're out of toilet

${ }^{1}$ John E. Biersdorf, How Prayer Shapes Ministry (Washington, DC: Alban Institute, 1992), xi.

${ }^{2}$ Ibid., $\mathbf{x}$. 
paper and somehow that should not be merely irritating to our prayer life but we should see those things as, in a sense, lofty too. Brother Lawrence, who wrote The Practice of the Presence of God, was like that. He lived in the presence of God no matter what he was doing. He certainly dealt with the mundane, yet he was able to see that as prayer. He was as content in his prayerful presence of God as he was in the chapel. I think he was happier in the kitchen, and we're not always real good at that.

When I was in seminary people kept talking about not wanting to know how to use the Xerox machine. I know how the Xerox machine works. Sometimes I'm called upon to fix it, if I can. That comes back to this whole thing that I think you need to integrate work with prayer. And just as you need to be humble before God, simple before God, you also ought to be willing to be simple before the vacuum cleaner.

The pastor's struggle to integrate being and doing is in part the result of others' expectations. Adam made that clear when he said,

I remember a young teenager asking me once in all sincerity and in all naiveté or innocence: "What do you do all week?" Just like we're sitting around, reading a book, or something. She was expressing a certain feeling about that. The other thing that I know that lay people seem to enjoy is that they like to see their pastor busy, they like to see their pastor out. The pastor's at Rotary. Boy, that's great. Like I'm in the newspaper twice a week, so that's great.

Dan also remembers being asked a similar question. A little boy, who had not yet learned that the polite constraints of society should keep you from asking such prying questions, wanted to know from him "what preachers do all day?"

People simply do not understand that praying is part of the pastor's work.

Prayer just does not seem like it qualifies to be our work-at least it does not to our parishioners. Does it to us as pastors? According to Gisbert Greshake we find that, "Prayer, in a word, is unsatisfying." He goes on to acknowledge,

The strong temptation to abandon it and to spend the time in doing other, 'more sensible', things, activities which produce more results-instead of kneeling silent and unsatisfied before God. How many people, on account of such an experience, abandon personal prayer or relegate it to the second or third place! There are more than enough 'alibis' for acting in this way with a good conscience-the pressure of pastoral work, constant interruptions, countless duties. Many priests consequently say, 'My work is a prayer', and feel released 
from a burdensome duty: the necessary tension between prayer and work is resolved in favour of work. ${ }^{1}$

We must ask if all the activities that demand our attention as pastors are really essential. Or, we might ask, as one pastor is reported to have done, "Am I missing the burning bush while trying to keep the lawn cut?" Surely something we are doing now is less important than praying. Speaking of the struggle between prayer and "productive work," Joseph M. Winger says, "Many pastors lament that too many deadlines, meetings, decisions, phone calls, and appointments rob their prayer times. Facing a similar dilemma, early church leaders decided, 'We will devote ourselves to prayer, and to the ministry of the Word' (Acts 6:4)."2

\section{A Means of Self-Justification}

The Bishop of Jarrow wrote one of the most insightful essays available on the subject of the pastor and prayer entitled, "The Priest as a Man of Prayer and a

Teacher of Prayer." It originally appeared as an article in the British journal,

Theology, and was later included by the journal's editor, G. R. Dunstan, in the book, The Sacred Ministry, which he edited. The Bishop of Jarrow wrote,

I suspect ... that the increasing interest which some clergymen are showing in social and welfare work, and the emphasis which is now being placed on Christian action in the secular world, are not simply due to the laudable desire to minister more effectively in Christ's name to the needy and the oppressed. They are due, in part at least, to a feeling that it is essential for the clergy to justify themselves to themselves and to other people. It is a modern version of justification by works. Unless a priest is meeting an obvious need or doing something which the man in the street immediately recognizes as useful, he may be tempted to assume that his work is valueless. All too rarely is there sufficient appreciation that, because man is made by God and for God, the greatest service

\footnotetext{
${ }^{1}$ Greshake, 157.

${ }^{2}$ Joseph M. Winger, “Hidden Efficiencies of Prayer," Leadership 14, no. 4 (Fall 1993): 46.
} 
one human being can do for another is to bring him into closer union and fellowship with his Creator. ${ }^{1}$

The bishop's damning assessment that the feeling that we must justify ourselves by our busyness is "a modern version of justification by works" strikes straight at the heart of the pastor's dilemma. He carries our conversation about the place of prayer in the pastor's work far beyond it being a simple matter of our personal priorities to show that prayer is the very essence of our work as ministers of the Word. We are called to point people to Jesus as their Savior and not to model an alternate method of salvation. Prayer is not simply a tool to make our ministry productive. It is central to the pastor's work because it is first of all a confession of our utter dependence on the power of God to accomplish His ministry through us. In prayer, we place ourselves where that can happen.

Pastors have trouble with this, however. Carl told me that early in his ministry a friend repeatedly said to him, "Christians make me sick because you just want to sit around and pray for people while the Jaycees do things. We put food on the table for people. We do things for people and you Christians just pray for people all the time. The hands that work are more holy than the hands that pray." Carl went on to explain that

what keeps us from praying is that oftentimes we believe like that man did that the hands that work are more holy than the hands that pray and I've got so much to get done that the Lord's not going to do it for me. He expects me to do it myself. So somebody needs bread on their table, I shouldn't pray for them. I should go get them a loaf of bread. This person is discouraged, I shouldn't pray that they be lifted up. I should go lift them up. And sometimes we become so involved in the doing that we forget we have the power to do through Christ.

\footnotetext{
${ }^{1}$ The Bishop of Jarrow [A. K. Hamilton], "The Priest as a Man of Prayer and a Teacher of Prayer," Theology 71, no. 571 (January 1968): 8.
} 
And I think that gets in the way of my prayer life. So the very thing that makes my prayer life strong is also an area that can make it weak because I become so involved in doing that I don't allow the Lord to do.

My next interview with Carl came after he had been part of an evangelistic mission to eastern Europe. In our conversation Carl came back to his friend's adage about the hands that work being more holy than those that pray. This time he said it differently, modifying the saying to reflect his own understanding. What he now said was, "The hands that work are more holy than the hands that just pray." What Carl meant was that we must get up off our knees and work. He contends that, "If prayer has not led you to service, then you had better examine your prayer life." I have no argument with Carl in this regard. What I believe is significant, however, is how this worked out in Carl's ministry recently. Trying to minister in a situation where his ability to communicate was limited, Carl said,

I found myself praying for the Lord to touch hearts in ways that I was not able to do because of the language barrier. I found myself praying many, many times for those people whom I was unable to talk with, but I know God could. Here I probably would not be talking to God quite so much, but I would be doing something. I had to modify what my friend had told me, "The hands that work are more holy than the hands that just pray." I think that prayer is a very important and vital part of what is happening, but you also have to get up and get going and doing and I think that is an important part of life and an important part of the ministry. I was not able to do my normal part in Russia and therefore I think I relied more on prayer than I do here. There all I could do was pray. I found myself in a situation where I had no choice but to pray for God to intervene. It was frustrating for somebody who likes to do, not to be able to do.

In Russia, Carl was not able to perform his customary pastoral role of "doing," not because his hands were more or less holy, but simply because they, along with his tongue, were tied. This experience provides us with another striking view of the pastor's dilemma. Even when circumstances handed him the less familiar role of "just praying," Carl balked at it. He apparently did so because of the 
specter of his friend's criticism and his own distress at the idea of "just praying."

\section{Pastoral Identity}

What distinguishes the work of the pastor from that of anyone else? What gives us our pastoral identity? Should it be something as visible as the clerical collar worn by some in our calling? When I showed Adam the Nick Hobart cartoon (see appendix B) of the man with patches where you would expect them-on the elbows of his jacket-in conversation with the pastor who has patches where you would not expect them-on the knees of his trousers-I asked him those questions. Adam responded by saying, "This expresses what our lives should be saying, 'Yes, I am both working and I am doing the work on my knees that I ought to be doing.'”

The pastor's calling may be to spend more time on her or his knees than others do. A life of prayer, however, is not all there is to ministry. The being and the doing must be integrated. Adam says,

I think it is important that as a pastor my prayer life lead into all this other stuff so that I'm not just someone who is a good administrator. It would be easy for me to just be geared towards getting things done. But, what are we really about here? Sometimes I get confused and I think what I'm really about is to accomplish $\mathrm{A}, \mathrm{B}$, and $\mathrm{C}$ and what I'm really about is to be A, B, and C and those $\mathrm{A}, \mathrm{B}$, and $\mathrm{C}$ are different than the things I've accomplished.

Our self-understanding shapes the identity we project to others. Who am I called to be as a pastor? Which of Samuel W. Blizzard's six roles, ${ }^{1}$ or Clapp's eight functions, or however many jobs there are which are part of our ministry, provides us with our identity as a pastor? The place of prayer in ministry should be an

\footnotetext{
${ }^{1}$ Blizzard distinguished six roles within the work of the parish minister: administrator, organizer, pastor, preacher, priest, teacher. Blizzard, 508.
} 
important factor in the pastor's self-understanding according to Greshake. In the following paragraph he says,

Prayer provides an important criterion for a priest's understanding of himself. It brings up a basic question: How does he see himself-as a pastoral 'manager' or as a man of God, as a mere 'functionary' or as one who does his work in union with Christ? Without prayer, pastoral care eventually becomes superficial and at best distorted into a business operation. A priest who does not pray becomes unable to recognise what is essential, and consequently fails to notice God's call in daily life: his words and action do not derive from listening to God's word. A bishop once said, 'I need to listen only two or three minutes to a priest's sermon, and then I know if he prays'. Does not the community also notice this? ${ }^{1}$

The question about the pastor's accountability to the community must not be overlooked. Greshake rightly points out what the pastor must remember, and that is that prayer is not merely his own individual concern. Greshake insists that "the community has a right to a pastor who is not constantly taking refuge in activity, thus running away from himself. Instead they have a right to one who 'faces up to' God and himself." ${ }^{2}$ Wendell W. Frerichs makes a similar point when he says, "A pastor who does not pray regularly or help others to do so is surely living a contradiction of some kind. How can one presume to speak and act for God while failing to speak with God?"3

Adam understands the importance of prayer as part of his ministry to his congregation and the community in which he works in a comparable way. He says, "If I'm going to pray with people I should be about prayer. Sometimes I almost feel like I don't have any right to come into the office till I've prayed." And yet as a

\footnotetext{
${ }^{1}$ Greshake, 158.

${ }^{2}$ Ibid., 159.

${ }^{3}$ Wendell W. Frerichs, “The Pastor's Prayer Life,” Dialog 32, no. 1 (Winter 1993): 29.
} 
priest, Adam is aware that "what we're called to do and be is not just a job." Unfortunately prayer can be just a job. Adam told me that when he prays as part of leading his congregation in worship he has to work at not being just the "master of ceremonies." When I asked Adam if he saw prayer as his work, his response indicated that "work" can be understood in the negative sense of duty or obligation. Adam says, spending time in prayer is "not just my responsibility but it's something that ultimately brings me to wholeness-like someone who, say has a workout that they might do. They don't necessarily enjoy it, but they know that if they want to be healthy they're going to do it." Urban T. Holmes says, "We do not pray because we feel like praying, we pray because we know that this is a fulfillment of our vocation: to live as spiritual beings."1

Another dimension of the pastor being accountable to the community is that prayer cannot be considered peripheral to the practice of ministry. Prayer must be understood as an integral part of the pastor's work. That this concept is foreign to many is seen in this fictional, but all too real, conversation described by John Richard Neuhaus: “'Is the pastor busy?' asks the caller. 'No,' says the church secretary, 'he's just reading,' No, he's not busy, he's just thinking. No, he's not busy, he's just praying." 2 Just praying? Adam, the Episcopal priest I interviewed, wants to know just "whose company is this?" A wishful Donald E. Messer imagines a very different scene when he writes, "How refreshing it would be for laypersons to call the church office only to be informed that the pastor was in prayer and would

\footnotetext{
${ }^{1}$ Holmes, 170-171.

${ }^{2}$ Neuhaus, 204.
} 
call back later!"1

\section{Prayer and the Pastor's Work}

Having discussed two of the major themes which emerged from my interviews with my five pastor friends, I now turn more specifically to the question of how prayer is part of the pastor's work. Prayer should be an integral part of all of the pastor's functions. The relation between prayer and preaching is obvious as should be prayer's relation to pastoral care. In addition, I believe that prayer stands alone as a pastoral function. I doubt, for instance, that anyone would argue that intercessory prayer is not vital to the work of the pastor.

\section{Preaching}

In the previous chapter I discussed the apostles' limitation of their work "to prayer and the ministry of the word" (Acts 6:4). I want to continue that discussion by asking what that decision has to say to ministers today. Bede Frost wrote about our "preoccupation with external things and ... futile activity which has become more and more characteristic of an apostolate which had been better devoted 'to prayer and the ministry of the word' of God."2 Yes, it would be better if the successors to the apostles would follow them in devotion "to prayer and the ministry of the word." Prayer must be seen as part of our work as it was of theirs. Over a 1989), 131.

${ }^{1}$ Donald E. Messer, Contemporary Images of Christian Ministry (Nashville: Abingdon Press,

${ }^{2}$ Bede Frost, The Art of Mental Prayer, with a preface by Abbot Denys of Nashdom (London: S.P.C.K., 1960), 44. In spite of Frost's willingness to dismiss me as a heretic I still agree with him on this point. Although careful not to criticize individuals, Frost dismisses Protestantism as heretical in his zealous defense of Catholicism. See Frost, 12. 
century ago, Alexandre Vinet wrote in his Pastoral Theology, prayer "is not only a preparation for the ministry, it is one of its labors for the accomplishment of which the first ministers of Jesus Christ demanded a discharge from certain secondary functions: We must, said they, give ourselves to this."

We too must give ourselves to these two primary functions of ministry because, as P. T. Forsyth said, "The ministry of the Word and prayer go together. The man who prays as much as he preaches will not be an ineffective preacher." Not everyone sees prayer as a significant role for the pastor; they do see preaching as important, however. What is the relation between prayer and preaching? Preachers need to be nourished in prayer because it is their daily bread according to Patricia Wilson-Kastner. She reports that "every lecture or book about preaching admonishes the preacher to pray as an essential part of sermon preparation. How could anyone dispute such advice? If preaching is proclaiming the Word of God, ... the preacher must be always rooted, grounded, and living in prayer."

Erwin W. Lutzer, senior pastor of Moody Church in Chicago, Illinois, says, "Praying is more important than preaching." ${ }^{4}$ Prayer precedes preaching in Acts 6:4. Our preaching must begin in prayer. Richard Lischer reports Rudolf Bohren's comment made to an international conference of homileticians that "the best

${ }^{1}$ A. Vinet, Pastoral Theology; or, The Theory of the Evangelical Ministry, trans. and ed. Thomas H. Skinner (New York: Ivison, Phinney, Blakeman \& Co., 1866), 115.

${ }^{2}$ Forsyth, The Church and the Sacraments, 148.

${ }^{3}$ Patricia Wilson-Kastner, Imagery for Preaching (Minneapolis: Fortress Press, 1989), 62.

${ }^{4}$ Erwin W. Lutzer, "The Priorities of the Preacher," Moody Monthly 87, no. 1 (September 1986): 33 . 
preparation for preaching is not rhetorical technique but training in prayer." $\mathrm{A}$ publication of the Bishops' Committee on Priestly Life and Ministry of the National Conference of Catholic Bishops says, "The preacher is thus called, above all, to be prayerful. The prayer we speak of is not prayer alongside of preparation for preaching, or over and above this preparation, but the very heart and center of the preparation itself." My pastor friend, Dan, told me that "out of time alone with God comes the equipping to preach."

"Learn to pray," is Ben Patterson's advice to preachers. He says,

I think it was D. L. Moody who reminded us that Jesus taught His people how to pray, not how to preach. I guess I would rather learn how to pray than how to preach. I have a great distrust of my abilities. God has given me some abilities to communicate, and I think those gifts are, taken alone, what I think will thwart my effectiveness in the kingdom of God. Prayer allows me to relinquish my hold on preaching and cast myself on the mercy of God. That's when God can use me. ${ }^{3}$

We would do well to note Patterson's reason for advising preachers to learn to pray. He says God can use only preachers who are dependent upon Him. Robert N. Rodenmayer says, "Prayer is another way of saying dependence on God and that is what the Christian ministry exists to be and teach and do." What is the minister to be? What is the minister to do? Rodenmayer says the minister exists to teach dependence on God.

${ }^{1}$ Richard Lischer, "Other Voices in Homiletics," Homiletic 16, no. 1 (Summer 1991): 3.

${ }^{2}$ Fulfilled in Your Hearing: The Homily in the Sunday Assembly (Washington, DC: United States Catholic Conference, 1982), 11.

${ }^{3}$ Ben Patterson, "Interview: Ben Patterson," interview by R. Albert Mohler, Jr., Preaching 6, no. 3 (November-December 1990): 31.

${ }^{4}$ Robert N. Rodenmayer, We Have This Ministry (New York: Harper \& Bros., 1959), 109. 
Speaking about prayer, Robert E. Coleman acknowledges, "How easy it is to ignore this dimension of ministry, especially when under pressure of many demands. We tend to go right ahead with the work, assuming our self-sufficiency." In contrast, Coleman notes that Jesus "was never too busy to talk with his Father. Other things were necessary, but prayer was indispensable. Prayer was his primary way of getting things done." ${ }^{2}$ Someone once said, "When we work, we work. When we pray, God works." That means our ministry is but an "extension of God's answer to our prayers,"3 or as Norman C. Pavey said, it is "a reflection of our prayer."

In his book Prayer and Preaching, Karl Barth writes that "in every expression of faith and obedience, it is prayer that brings us into a relationship with God and allows us to be fellow-workers with him." ${ }^{5}$ I think that is what Adam meant when he said, "Prayer somehow makes us Christians. It suggests that a person is in relationship with God."

\section{Pastoral Care}

There is a link between pastoral care and prayer. There is probably no area

${ }^{1}$ Robert E. Coleman, "The Prayer Life of the Christian Minister," in A Celebration of Ministry: Essays in Honor of Frank Bateman Stanger, ed. Kenneth Cain Kinghorn (Wilmore, KY: Francis Asbury Publishing Company, 1982), 80.

${ }^{2}$ Ibid., 82 .

${ }^{3}$ McCutcheon, 19.

${ }^{4}$ Norman C. Pavey, "Praying for Your People," The Christian Ministry 24, no. 2 (March-April 1993): 22 .

${ }^{5} \mathrm{Karl}$ Barth, Prayer and Preaching, trans. Sara F. Terrien and revised by B. E. Hooke (London: SCM Press, 1964), 23. 
of ministry where the pastor is more keenly aware of how woefully inadequate just praying is than in pastoral care. At the same time, the pastor recognizes that prayer is his or her most valuable "tool" when it comes to ministering to those in need. Peter Davie regards prayer "as fundamental to pastoral care." But Ralph L. Underwood still complains that "pastoral care ministry pays little attention to prayer." $\mathrm{He}$ advances "the thesis that prayer is the soul of pastoral care, and that it is time to give prayer central place in pastoral theory as well as practice."3

One pastor who gives prayer central place in pastoral care is Donald Raymond Black. In his Doctor of Ministry thesis, "Intercessory Prayer in Pastoral Care," he says prayer is the unique thing the pastor brings to the crisis situation. Moreover, it is vital, and its neglect has been to the detriment of pastoral care. Black says, "I pray because I am a pastor, because of an obligation I have, but also because I care for my people and use the means of helping them that was used by Jesus Christ and other Old and New Testament "pastors." 4

Gary L. Gulbranson identifies prayer as one of the spiritual resources available to the pastor in counseling. He says, "Prayer represents the spiritual side of counseling. Our prayers show we do not ultimately rely on our education, skills, or methods but on God's Spirit to work in this situation. Prayer is a confession of

\footnotetext{
${ }^{1}$ Peter Davie, Pastoral Care and the Parish (Oxford: Basil Blackwell Publisher, 1983), ix.

${ }^{2}$ Ralph L. Underwood, Pastoral Care and the Means of Grace (Minneapolis: Fortress Press, 1993), 13.

${ }^{3}$ Ibid., 14.

${ }^{4}$ Donald Raymond Black, "Intercessory Prayer in Pastoral Care" (D.Min. thesis, Princeton Theological Seminary, 1982), 8.
} 
weakness that allows God's power to prevail."'

No author makes the point more strongly that prayer is vitally linked to pastoral care than Eduard Thurneysen, who says, "Pastoral care is prayer."

According to him,

each and every act of pastoral counseling has to arise out of the attitude of prayer. No wisdom, no psychological knowledge, no psychic power we may be able to demonstrate in our pastoral talk, and no action accompanying our talk, hence no practical technique for the benefit of man, however effective, can replace the decisive act of prayer. ... In the center and at the heart of pastoral care, prayer must stand out as its principal activity. Praying is truly the one decisive action in which the pastoral counselor must be engaged ever anew and without intermission. The practice of pastoral care and prayer are actually one and the same. Pastoral care is prayer. ${ }^{2}$

Lately in his counseling, Dan has been teaching people how to pray and the role of prayer in the process of healing. He tells them, "I am sorry, I can't heal you, but I know someone who can heal you, and what you need to do is to go to my friend, Jesus, and talk to Him." Dan teaches them to pray,

I have been trying to take care of the pain of the past by myself, and I can't take it away, so I am going to give it to You, because You know what to do with it. You can throw it in the ocean with Your grace so that it will never come back and trouble me again. And then I am asking You to give me peace and to give me purpose in life.

Dan then prescribes this daily prayer for his counselees: "God, thank You so much for taking my pain, and thank You that right now You are giving me peace and purpose and every day I will thank You for that."

Prayer is also part of every one of Ben's counselling sessions. After telling

\footnotetext{
${ }^{1}$ Gary L. Gulbranson, "Using Our Spiritual Resources," in Mastering Pastoral Counseling, ed. Archibald Hart, Gary Gulbranson, and James Smith (Portland, OR: Multnomah Press, 1992), 16.

${ }^{2}$ Eduard Thurneysen, A Theology of Pastoral Care, trans. Jack A. Worthington and Thomas Wieser (Richmond, VA: John Knox Press, 1962), 190.
} 
me that he has discovered that he has gifts in the areas of healing and of God's

presence, Ben described the following extraordinary phenomenon:

When I am counseling with somebody or working with someone who has a need of prayer I get-I don't even know how to say this without sounding stupid-I get called to pray for them. At a particular point in the conversation it will be like, God says, "Okay, it's time now. You pray with them now." And the way it works for me, at least, is that whenever it's that time my hands get hot so there's an area in the center of the palms of both my hands that just warms up and I can feel the temperature difference in my hands and that's time to pray.

In his book, The Approaching Sabbath: Spiritual Disciplines for Pastors,

Thomas R. Swears relates the need for pastors to spend time in prayer to their effectiveness in providing pastoral care. He says,

For there to be times when the pastor isn't accessible to the people, times when the door to the study is closed because the pastor is praying, is not a faithless act. It is, rather, close to the heart of faithful pastoral care. . . . It is important for the people to know that the pastor has spent time alone in the presence of God, to know that the pastor has stood still on holy ground on their behalf. ...

Times of solitude and prayer do not detract from the tasks of active ministry; they deepen and enrich them. Having spent time alone with God in prayer clarifies and deepens the quality of time, the quality of care, and the quality of prayer that is offered from the altar, at the hospital bedside, or in the counseling session. To be regular in such times set aside for prayer is not to be selfish. It is faithfully to fulfill a central task of the pastor's calling, which is to be an intercessor before God for those given into the pastor's spiritual care. ${ }^{1}$

\section{Intercession}

In his autobiographical article, "Prayer and Work, Mostly in South Africa,"

the Anglican priest, Timothy Stanton, recounted how as a youth he was told, "If you are going to be a priest, you must be a man of prayer." ${ }^{2}$ Looking back on his

${ }^{1}$ Thomas R. Swears, The Approaching Sabbath: Spiritual Disciplines for Pastors (Nashville: Abingdon Press, 1991), 58-59.

${ }^{2}$ Timothy Stanton, "Prayer and Work, Mostly in South Africa," Review for Religious 52, no. 4 (July-August 1993): 553. 
lifetime in ministry, Stanton says, "Prayer has always been important to me. As a priest and a monk, I consider prayer the most important work that I have to do. To me a priest is an intercessor."1

In the service for "The Ordering of Priests" in the Anglican and Episcopal churches, the Bishop asks, "Will you be diligent in Prayers?" Then the priests who are being ordained are to answer, "I will endeavour so to do, the Lord being my helper."2 Michael Ramsey, then Archbishop of Canterbury, explains that what the priests will endeavor to do with the Lord's help is to be intercessors. He wrote,

Now we can begin to see what is our own role as men of prayer, as priestly intercessors. We are called, near to Jesus and with Jesus and in Jesus, to be with God with the people on our heart. That is what you will be promising when I say to you "will you be diligent in prayers?" You will be promising to be daily with God with the people on your heart. ${ }^{3}$

Ramsey's understanding of intercession corresponds to the definition given by Koenig, who says it is "communion with God for the sake of others." ${ }^{\text {As }}$ intercessor the pastor "stands at the intersection of the human and the sacred." Protestants have been reluctant to ascribe to the pastor priestly functions. But over a century ago, the Swiss Reformed theologian, Alexandre Vinet, described pastoral prayer as a function and said, "The prayer of a pastor is sacerdotal prayer." Dan,

${ }^{1}$ Ibid., 563.

${ }^{2}$ The Book of Common Prayer (New York: Oxford University Press, 1952), 542.

${ }^{3}$ Ramsey, 14.

${ }^{4}$ Koenig, 167.

${ }^{5}$ Jack L. Seymour, "Teaching as Religious Leadership: Rethinking the Pastoral Role," Quarterly Review 3, no. 3 (Fall 1983): 8.

${ }^{6}$ Vinet, 116. 
one of the Seventh-day Adventist pastors I interviewed, sees intercession as an integral part of his work. He says, "I think that part of my role as a pastor is to pray and not just for myself, but for my people." Ben describes himself as an intermediary, an agent through whom God can work, in sharing the following colorful personal analogy:

Sometimes I call myself a lightning rod when I pray with somebody. I stick one hand up in the air and lay the other hand on the individual and say, "All right Lord move through me." That's all I am. I'm not the actor. I'm just the lightning rod that's grounded and allows God to work.

On one hand, prayer is not considered to be a major part of the pastor's work and yet, on the other hand, pastors are expected to always be at prayer. When I showed Dan the Joseph Farris cartoon (see appendix B) of the pastor who had placed a silhouette of himself praying in front of the window he said,

I think this pastor wants to be a well-rounded person and he does not know what to do with the congregation's expectation that he should be praying all the time, so he puts up the front in front of the window. And, I would judge that he probably lives with some guilt even though he puts the cardboard-praying pastor in front of the window.

Although the pastors I interviewed wished more people would understand that prayer is part of their work, they are annoyed when prayer is seen as their only work. Adam indicated that he felt uncomfortable when called upon to offer "state occasion prayer" as the ex officio "pray-er" at church and community functions. He is not the only pastor who dislikes it that "prayer is often viewed as part of ritual behavior-a part of what is expected of clergy when ministering in the presence of others." Dan told me, "I resent when people think that I should pray because I am

\footnotetext{
${ }^{1}$ Underwood, 13.
} 
the pastor. I would like people to see me as other than the person who opens official functions.”

Another perspective on the matter of pastors being asked to pray as a ceremonial duty is offered by Eugene H. Peterson. He says, "The pastor is, in these settings, what the theater calls 'fifth business'-required by the conventions but incidental to the action, yet, in its own way, important on the sidelines." 1 Peterson argues that "our real work in every occasion that requires a priestly presence is prayer. Whether anyone there knows or expects it, we arrive as persons of prayer."2 There is a contradiction here. While pastors want to be recognized as persons of prayer, they resent it when it is the only role they are allowed to perform. Could this be more evidence of the extent to which pastors have succumbed to the expectation that they must do something more "useful" than just pray?

\section{Prayer: The Pastor's Prime Work}

In an article published in The Christian Ministry, Christopher Evans, while sweeping up the rice left in the chancel after officiating at a wedding, says,

I thought back to my seminary days when I'd envision the direction my ministry would take in the years ahead. I'd see myself in many roles-as a preacher, counselor and "empowerer" of laity. Never did I see myself sweeping up rice after weddings! That afternoon, as on other occasions before and since, I found myself musing over the question, "Is this the work that I'm called to do?"3

What work have pastors been called to do if it is not sweeping up rice after

${ }^{1}$ Eugene H. Peterson, “Mastering Ceremonies.” Leadership 8, no. 2 (Spring 1987): 89.

${ }^{2}$ Ibid., 91.

${ }^{3}$ Christopher Evans, "Rediscovering Grace in an Impossible Calling," The Christian Ministry 25, no. 1 (January-February 1994): 14. 
weddings? In 1990, Leadership published a letter David Hansen wrote in response to the perennial question that plagues pastors, "How do you sort the necessary from the merely urgent?" Hansen's letter, written to a young pastor beginning a new ministry, urged him to concentrate on the fundamentals. They are two, he said. The first: minister the Word of God. The second: pray. Hansen wrote, "Prayer is your work. It is your prime work. . . . There is absolutely no ministry without prayer!”1

No one said it more bluntly than P. T. Forsyth, the British Congregationalist divine, who wrote in 1907, "A preacher whose chief power is not in studious prayer is, to that extent, a man who does not know his business. . . Prayer is the minister's business." ${ }^{2}$ When I read Forsyth's statement to Ben, he responded with his characteristic bluster, 'It's great, it's wonderful, highfalutin. But I don't think it means two cents in today's ministry because I don't think ministers have the time considering all the other demands made on them to really do that kind of thing. I think they'd love to have it."

What might be a more thoughtful perspective is offered by J. David Bridge. He says a minister is one who prays. Through prayer, the minister must become attuned to what God is doing just like every other Christian. But Bridge adds,

The ordained ministry has two special characteristics with regard to prayer. Firstly we have more time for it than many people. Secondly it is our privilege to lead others in prayer in public worship. At the top of my list of priorities must come therefore time for prayer and time to cultivate a richer experience of prayer. $^{3}$

${ }^{1}$ David Hansen, “Upon Taking a Small Church,” Leadership 11, no. 2 (Spring 1990): 79.

${ }^{2} \mathrm{P}$. T. Forsyth, Positive Preaching and Modem Mind London: Hodder and Stoughton, 1907), 190.

${ }^{3}$ Bridge, 37. 
Holmes says, "The ordained person is expected to be a person of prayer that the person in the street cannot be."1

Eugene Bradford has "no doubt that the Holy Scriptures teach that intercessory prayer is a ministerial task." ${ }^{2}$ He believes the commitment of the Twelve "to prayer and the ministry of the word" (Acts 6:4) provides a scriptural basis for claiming that "the minister is called to pray as a part of his official duty."3 Bradford wants the minister's attention called to this important passage because in it, he says, the Twelve set an example of ministry dedicated to "prayer and the ministry of the word" that is still valid for Christian ministers today.

Andrew Watterson Blackwood also uses Acts 6:4 to point out that the apostles delegated necessary work so they could give themselves to "prayer and the ministry of the word." Then Blackwood said,

The Lord does not commission and train a man to preach and then put him in charge of a three-ring circus, taken over from a predecessor, and destined to keep growing "bigger and better" under a person too busy to study and too bothered to pray. Son of Martha, "thou art careful and troubled about many things: but one thing is needful."

That one thing which is most needed is prayer.

\section{Pastor, Are You Praying?}

Far too many things are expected of the pastor today, complains Bradford.

\footnotetext{
${ }^{1}$ Holmes, 34.

${ }^{2}$ Bradford, 14.

${ }^{3}$ Ibid., 15.

${ }^{4}$ Andrew Watterson Blackwood, Doctrinal Preaching for Today: Case Studies of Bible Teachings (New York: Abingdon Press, 1956), 94.
} 
He says, "There is a shameful lack of concern on the part of most laymen as to how the minister apportions his time. . . They never ask, 'When does our minister ever get time to pray for us in our need?'”1

Never ask? Well, they almost never ask. In a paper read at the Maynooth Union Summer School in 1969, Marie Arnall states emphatically that she expects her priest to pray. She writes,

I, one of the people whom you serve, expect you to allot time each day to personal prayer, and to be as firm in withdrawing from others to this time of prayer as you are about any of the principles you hold, or any of the gospel that you teach. You are of no use to me if you do not confront God in personal prayer. $^{2}$

I make no claim that my survey of the literature dealing with the pastor and prayer has been exhaustive. Surely there are testimonies of other laypersons which could be produced to affirm the praying of their ministers. That appears to be what Bishop Richard J. Sklba is searching for when he writes,

Catholics can only be commended when they seek the fruits of prayer in the activity of their bishops, and when they cooperate to make room for that work of God in the lives of their shepherds. The bishop who never hears his people ask whether he prays regularly and well is deprived of a powerful stimulus to his own growth in spirituality.... They also have the obligation to reshape the scope of their bishop's responsibilities so that, like the Twelve who initiated the table ministry of the seven (Acts 6:1-6) in order to be freed for "prayer and the ministry of the word," he might be about the primary task which is his. ${ }^{3}$

Dan, one of the two Seventh-day Adventist pastors I interviewed, indicates that he is disappointed that there is no one who holds him accountable for his

\section{${ }^{1}$ Bradford, 45.}

${ }^{2}$ Marie Arnall, "His Prayer," in Priest: Person and Ministry, ed. Gerard Meagher (Dublin: Gill and MacMillan, 1970; London: MacMillan and Co., 1970), 165.

${ }^{3}$ Richard J. Sklba, "Bishop, Prayer and Spirituality," Worship 57, no. 1 (January 1983): 67-68. 
personal prayer life, or anyone who encourages him in it. But he adds,

If I don't pray, nobody will put my nose to the grindstone. I have to find a way to pray. ... I have come to the conclusion that prayer is my responsibility. The bottom line is that it is my responsibility. I only wish that somebody would encourage me in my prayer and challenge me and affirm me that praying is an essential part of my work.

Dan's experience was shared by the other pastors. Ben, whose church members call on him instead of the deacons to care for the maintenance of their sanctuary, could not recall any of them ever asking him, "How is your prayer life? Have you had time to pray?" When the church had to reduce Ben's work from full time to part time because of a financial crunch, he managed to renegotiate his job description. He told me, "I charge 10 percent of my time off to personal piety. That includes my own prayer life, it includes meditative time." I asked Ben how the congregation felt about that. He said,

I received a pretty good response on that. I think most people understood that was part of the job and didn't think of it as a waste of time or doing nothing. I was kind of surprised-at least the people who were most directly involved with the process were ready to accept that as part of what we were doing. "Yeah, that was your job." It was just as important as going out in the community and doing something.

\section{Rethinking the Pastor's Work}

There are pastors, churches, and even denominations that are reevaluating prayer as a part of the pastor's work. According to Jerome D. Quinn, the Second Vatican Council's acknowledgment that the primary ministry of the church is prayer "has demanded a searching and critical rethinking of the raison d'être of the ordained ministry whose task and service it has been to teach and guide and enrich 
the prayer of the Church." ${ }^{\prime \prime}$ However, the rethinking of the place of prayer in the work of the pastor by a few Protestant and Roman Catholic theologians has not yet caught up with everyone in the church.

McCutcheon's contention that "the essential foundation of the parish ministry today" remains "a private professional devotional life"2 runs counter to the more popular current understanding of what is essential for successful ministry. George Barna is

convinced that there are just a handful of keys to successful ministry. One of the indispensable characteristics of a ministry that transforms lives is leadership.

This may sound simplistic. Unfortunately, relatively few churches actually have a leader at the helm. In striving to understand why most churches in this country demonstrate little positive impact on people's lives, I have concluded that it is largely due to the lack of leadership. ${ }^{3}$

Is it really the lack of leadership, or is it the lack of leaders who pray that is at the foundation of the crisis in the church and among its ministers? In Acts 6, the Twelve made prayer their priority and delegated the administration of the church to others. Luke describes the tremendous impact the church had in Jerusalem following that decision. He says, "So the word of God spread. The number of disciples in Jerusalem increased rapidly, and a large number of priests became obedient to the faith" (vs. 7). Surely this incident describes successful ministry. Key to their success was the freedom of the Twelve to give their attention "to prayer and the ministry of the word" (vs. 4).

\footnotetext{
${ }^{1}$ Quinn, 479.

${ }^{2}$ McCutcheon, 11 .

${ }^{3}$ George Barna, Today's Pastors: A Revealing Look at What Pastors Are Saying about Themselves, Their Peers and the Pressures They Face (Ventura, CA: Regal Books, 1993), 117.
} 
Peterson points out that "in twentieth-century America the prophetic pastor of action and the managerial pastor are the ministry role models; the prayerful pastor leading people in worship draws, at best, a yawn." ${ }^{1}$ Pastors face unrelenting pressure to readjust their conviction of what pastoral work is. They are tempted to adopt the majority opinion and shape their work accordingly. All of this leads Peterson to ask,

Is there anything to be done about it, some one thing that will keep us at what we set out to do and were set apart to do? If we polled our pastor colleagues, as someone every now and then does, we would get a variety of responses. One response-which would be in predictably short supply, though-would be "prayer." I don't mean that the poll would show that pastors do not pray, but rather that they don't view prayer as the central and essential act that keeps pastoral work true to itself. ${ }^{2}$

\section{Consider My Friend Ben}

At the beginning of this chapter I noted McCutcheon's statement that "one of the chief reasons so many Christian clergymen are today leaving the parish ministry for other fields is rooted in a prior failure to establish and maintain ... a serious professional devotional life." ${ }^{3}$ McCutcheon may be right. Although none of my interviews confirmed this contention, I believe Ben would acknowledge that it is a possibility. He felt that all of the things which have taken the place of prayer in the ministry of the church are one of the reasons both church and ministers are suffering.

Ben suggested that the burnout among today's pastors is attributable to the ministry

being pulled in two different directions and then not being fueled as well as we should by God because we're not there enough for Him. You know, He's still able to do marvelous things. I think the reason it still functions at all is because

\footnotetext{
${ }^{1}$ Peterson, Working the Angles, 27.

${ }^{2}$ Tbid., 18.

${ }^{3}$ McCutcheon, 12 .
} 
God is in it but the problem is that many ministers are no longer filled with fuel and run out.

Pastors may, or may not, be leaving the ministry because of what is happening in their prayer life. But what I did discover was that the pastor's struggle to balance being with doing in their ministry eventually takes its toll. Ben told me, "If you hear a little frustration in this, it's because it's there. I'm at that point where I don't know if I want to do this anymore." He thinks that

if you're going to stay in ministry, and be effective in ministry and really be able to do what God has called you to do-not just what the church has called you to do, but what God has called you to do-I think it's an absolute necessity to be a man who is in touch with God-who walks with God.

What frustrates Ben is the "tyranny of the urgent," something he does not

believe Martin Luther had to contend with. ${ }^{1}$ He says,

Our ministry is much more active. ... We have a lot more things we have to do, and unfortunately that falls in nicely with our predisposition which is to be doing, to be going, to be accomplishing something concrete. Well, I spent an hour doing administrative stuff and I've got two letters and this and this and this to show for it, or I spent an hour and here's my outline for the meeting I've got to do tonight, or I've been an hour and an half in meeting tonight and that is what I did. That is much more in tune with what our world is about today-production -than prayer. What do you produce when you pray? You produce that intangible something - connection with God, and God assisting you in what you're doing, aligning yourself with His will. That doesn't compute, and it doesn't compute with many of our people today.

Ben's growing disillusionment with ministry may well be linked to the minister's dilemma identified by Blizzard. He said of ministers, "They actually spend most of their time doing those things they feel are least important." ${ }^{2}$ I think

\footnotetext{
${ }^{1} J$ ohn Koenig has a different perspective on Luther. He says, "It humbles me to recall that Martin Luther, who produced the equivalent of a hundred book-length manuscripts (by hand) and fathered six children in his relatively short life (1483-1546), is reported to have spent an average of three hours a day in prayer." Koenig, 29.
}

${ }^{2}$ Blizzard, 508. 
that is what Ben meant when he said, "I don't know of very many ministers who got into ministry because they felt called of God to be administrators. And yet, administration ... takes up an increasing portion of your time. So I think right there we have the tension and the dilemma of the ministry." Ben acknowledged that "churches need administrators. That's clear. At the same time they need men of God. That's also clear. The question is: Who does what?" Ben saw a move in his denomination to train pastors in management by objectives as wonderful. But he asked, "How do you determine what a measurable objective is when you deal with peoples' spiritual walk with God?"

At times Ben feels frustrated and disillusioned because of the dilemma he and his ministerial colleagues face, but he sees hope. His final comment to me indicated that it may all be worth it.

I feel-as we started let's end-the common guilt of many, many, many pastors is that we don't pray enough, that we aren't in the presence of God enough. At the same time I have to admit, as I think also every pastor would if pushed, we could find the time. So not finding the time is more than just not having the time, it's not prioritizing it, and maybe that's where a ton of the guilt comes in, so we blow off a lot of that because that's just too hard to accept. Yet I think almost all of us are in that position. And maybe if we did an hour a day we'd still feel guilty and like it should be two hours or three hours à la Martin Luther. I'm not so sure there ever is enough time to fully develop, enjoy, whatever the presence of God. Maybe that's why we have to look forward to something beyond what we're doing now. Maybe then, when we don't see so darkly in that darn glass, we'll be able to deal with that on a much better and on a more pleasant basis.

There were several dramatic moments during my interviews with my five pastoral friends. One came when Ben told me, "I'm at that point where I don't know if I want to do this anymore." My questions had given him permission to speak of his frustration. As he shared his disillusionment with me, I hurt with him. 
Looking "forward to something beyond what we're doing now" has always been part of how we compensate for a distasteful present. Certainly there is much to look forward to, but pastors must live in the present as well as the future. And if pastors are going to remain faithful to their sacred calling, they will need the grace that comes through prayer and the support of others in their lives of prayer.

Another moment of drama occurred when at the end of my final interview, I asked Eugene if I had missed something. I asked, "Was there something else you wanted me to hear?" Hesitatingly he asked, "Did I tell you about the time I was praying and the light came?" It was almost as if he was not sure the story was relevant to our interview. As he recounted how the light had come in response to his prayer, I was humbled. I felt like Moses in God's presence. This is what God has called us to. As pastors, we are to live prayerfully in His presence.

In the previous chapter, I described the biblical mandate for pastors to pray. In this chapter I have recounted the stories of pastors who struggle to be men of prayer in a church environment that subtly militates against their very calling. In all of this I hear pastors ask, "Let us pray." No, they are not just asking that we join them in reverently bowing our heads for the invocation or for a blessing. They are asking, "Let us pray." Let us be the pastors God has called us to be--pastors who pray. 


\section{CHAPTER IV}

\section{RETHINKING MY ROLE AS A PASTOR}

Recently while I was seated in an audience, I heard the President of the General Conference of Seventh-day Adventists, Robert S. Folkenberg, say, "It's time to rethink the role of our pastors." Initially, the thought that my church might meddle with my ministry frightened me. I was afraid ecclesiastical functionaries would try to redefine my job. But when I heard the world leader of my denomination say, "It's time to rethink the role of our pastors," I had another response as well. It was cautious interest. Was this an invitation for me to join a conversation to consider anew what Paul meant when he said, "God in his mercy has given us this ministry" ( 2 Cor 4:1 REB)? If so, then I wanted very much to be part of the dialogue.

The fact is that, even before I heard Folkenberg's call for the rethinking of the role of Adventist pastors, I was aware of a dialogue already underway attempting to do that very thing. In 1990, an Adventist publishing house released John W. Fowler's book, Adventist Pastoral Ministry. Fowler, a church administrator, writes of his concern that Seventh-day Adventists do not have a mature, balanced theology of pastoral ministry. This situation, he believes, demands "serious effort to clarify 
the role and function of the pastor."1 Fowler says that as heirs of the apostles the pastor's work is to be a minister of the Word of God.

A Seventh-day Adventist pastor, David Arnold VanDenburgh, takes issue with Fowler in his Doctor of Ministry dissertation, calling Fowler's book, "seriously deficient as a theology for ministry." ${ }^{2}$ VanDenburgh describes pastoral theology in the Seventh-day Adventist church "as a de facto or ad hoc theology. To make it deliberate and intentional we must, first, consciously recognize any bias that might already exist, and then, second, return to the Bible to begin to form a pastoral theology." 3 VanDenburgh's own perspective is that the pastor's work is "to equip the saints for the work of ministry" (Eph 4:12 NRSV).

\section{Teach Us To Pray}

The effort to rethink the role of the Adventist minister is of special interest to me because I, like my church, have not had a clear understanding of the nature of my work. Therefore, this project has been primarily a vocation-clarifying task for me. For some time now it has been my opinion that what is missing from this debate is any consideration of the pastor's historic identity as one who "is before all things a Christian soul given to prayer." 4

Before anyone objects that this is not an historic identity for Adventist

${ }^{1} \mathrm{~J}$ ohn W. Fowler, Adventist Pastoral Ministry (Boise, ID: Pacific Press Publishing Association, 1990), 15.

${ }^{2}$ David Arnold VanDenburgh, "The Effective Pastor: A Theology of Equipping Ministry for Seventh-day Adventist Pastors" (D.Min. dissertation, Fuller Theological Seminary, 1992), 7.

${ }^{3}$ Ibid., 187.

${ }^{4}$ Eleanor L. McLaughlin, "Priestly Spirituality," Anglican Theological Review 66, Supplementary Series, no. 9 (1984): 59. 
pastors, please consider Ellen G. White's statement, "Communion with God through prayer and the study of His word must not be neglected, for here is the source of his [the minister's] strength. No work for the church should take precedence of this." If nothing is to take precedence, then it follows that nothing should have greater priority for the pastor. In connection with her statement which I quoted earlier supporting functional apostolic succession, White says, "Ministers who are truly Christ's representatives will be men of prayer."2 A survey of White's published writings shows a reliance on Acts 6:4 for her understanding of the relation between prayer and the pastor's work. In a 1902 talk at a ministers' meeting in Los Angeles she said, "Those who enter the ministry engage in a special work and should give themselves to prayer and to the speaking of the Word." ${ }^{3}$ In another obvious reference to the resolve of the Twelve to be done with waiting on tables she wrote, "The minister should be free from every unnecessary temporal perplexity, that he may give himself wholly to his sacred calling. He should be much in prayer."

Fowler builds his case for the identity of the Adventist pastor on the biblical expression "ministry of the word," a term found uniquely in Acts 6:4. But nowhere does he acknowledge the connection Luke makes between "prayer and the ministry of the word," much less does he recognize the precedence prayer is given by the

\footnotetext{
${ }^{1}$ White, Testimonies, 6:47.
}

${ }^{2}$ Ibid., 4:529. I am aware of how White is misused in support of conflicting positions. My only interest is to establish that she does acknowledge prayer as an important dimension of the pastor's work and further, that she relies on Acts 6:4 to do so. 1946), 91.

${ }^{3}$ Ellen G. White, Evangelism (Washington, DC: Review and Herald Publishing Association,

${ }^{4}$ Ellen G. White, Gospel Workers (Washington, DC: Review and Herald Publishing Association, 1948), 145. 
Twelve. Fowler speaks of prayer as part of the pastor's work only as one of the spiritual disciplines. VanDenburgh's comment, "Jesus taught us that one called to prayer and the ministry of the word should not try to meet all the needs that cry out to be met,"1 is also an obvious reference to Acts 6:4. However, he too says little beyond this regarding prayer as a pastoral function.

Among recent Adventist publications, the only author I have read who gives a high priority to prayer as part of the pastor's work is Derek Morris. He declares, "Prayer is the focal point of my ministry." ${ }^{2}$ Morris, a former parish pastor who is now engaged in undergraduate theological education, made his comment in the 1991 book, The Adventist Minister. In the book's preface, Werner K. Vyhmeister, Dean of the Seventh-day Adventist Theological Seminary, describes it as "the first book prepared by Seventh-day Adventists attempting to draw a comprehensive picture of the minister, not only as a professional, but also as a person. Yet it does not claim to be exhaustive, nor does it attempt to be the final word." 3 It is greatly encouraging, however, to see that in the one chapter devoted to "The Minister as a Spiritual Leader," there is an extended discussion of Acts 6:1-7 and Morris' testimony, "Prayer is the focal point of my ministry."

The rethinking of the role of the Adventist pastor called for by Folkenberg is already in progress. With this project report, I have made it a point to be part of that

${ }^{1}$ VanDenburgh, 251.

${ }^{2}$ Derek J. Morris, "The Minister as a Spiritual Leader," in The Adventist Minister, ed. C. Raymond Holmes and Douglas R. Kilcher (Berrien Springs, MI: Andrews University Press, 1991), 25.

${ }^{3}$ Werner K. Vyhmeister, foreword to The Adventist Minister, ed. C. Raymond Holmes and Douglas R. Kilcher (Berrien Springs, MI: Andrews University Press, 1991), xi. 
process. This project has been part of my attempt to figure out what it means for me to be a leader in Christ's church. While this may be no more than an account of my personal pilgrimage, I also want to offer it as part of the conversation now going on among my ministerial colleagues regarding the nature of our work.

I write from over twenty years of the practice of ministry, from numerous conversations with colleagues, and from extensive review of studies that help to point out the problems and the possibilities which are part of our work. What I wish is that as we reconsider whatever pastoral theology we presently subscribe to, we would move intentionally to recover the apostolic function of prayer as a central part of our work as pastors. I wish that in our institutions, which train pastors, the same kind of emphasis would be given to prayer as to homiletics, and to spirituality as to apologetics. I wish that in the churches we serve, our members would hold us, as

their pastors, accountable to be men and women of prayer and not only to "wait on tables."

\section{Three Models}

Three specific biblical models of ministry exist which I want to consider in this regard. They are (1) the priority given to prayer by the Twelve in Acts 6, (2) Jesus' daily ministry between the mountain and the multitude depicted in Mark 1, and (3) the work of prayer in Epaphras' ministry described in Col 3.

\section{The Twelve: The Priority of Prayer}

In 1956 following the appearance of Blizzard's article, "The Minister's Dilemma," The Christian Century printed a letter of response from Wm. H. Schobert. 
He suggested, "It might do all of us well to read the account in the sixth chapter of Acts of the work for deacons and pastors." It is because pastors still face the same dilemma which Blizzard identified of spending most of our time doing those things we feel are least important that we keep coming back to this defining moment in the story of the early church for understanding the work of ministry. Would it not be appropriate to consider the commitment made by the Twelve to give their "attention to prayer," and not just to "the ministry of the word" as we rethink our role as pastors?

Joseph A. Fitzmyer says,

When the Seven are appointed to serve tables, this is done to allow the Twelve to engage in "prayer and ministry of the word" (Acts 6:4). Note the order of terms here: Luke clearly suggests that prayer is as important for the life of the Christian apostle as "the ministry of the word," i.e. the preaching of the Christian message. ${ }^{2}$

In Andrew Murray's book, The Prayer Life, he quotes a minister who asks, "How surprised people would be if I proposed to divide my time between these two equally—one-half given to prayer, the other to the ministry of the Word?" ${ }^{3}$ Who knows? There may be other equally surprising results of such a course of action. Luke says, "So the word of God spread. The number of disciples in Jerusalem increased rapidly, and a large number of priests became obedient to the faith" (Acts 6:7). Murray wrote in the foreword to his book,

${ }^{1}$ Wm. H. Schobert, letter to the editor in The Christian Century, 16 May 1956, 621.

${ }^{2}$ Joseph A. Fitzmyer, The Gospel According to Luke (I-IX): Introduction. Translation, and Notes, 2d ed., Anchor Bible, vol. 28 (New York: Doubleday, 1981), 246.

${ }^{3}$ Andrew Murray, The Prayer-Life: The Inner Chamber and the Deepest Secret of Pentecost (Chicago: Moody Press, n.d.), 114. 
Early copies of the book were sent out with the thought that if the leaders of the Church, ministers and elders, begin to see that in spiritual work everything depends upon prayer, and that God Himself is the helper of those who wait on Him, it would indeed be a day of hope for our Church. ${ }^{1}$

I see more hope for the church in prayer than I do in preaching and certainly more than in waiting on tables. In their book, Lay Ministry: Empowering the People of God, Lawrence O. Richards and Gilbert R. Martin, write, "One of the tragedies of the contemporary church is that it forces pastors ... to surrender their calling to a personal ministry in order to do the modern equivalent of waiting on tables-to administer and run the organizations and agencies of the church."2

Discussion of this one text has been interwoven throughout this project report. Robert J. Karris asks, “Does Luke's stress on the criterion of dedication to preaching the Word and prayer say anything about the responsibilities of Christian ministers today?"3 I think it does. The Seven were appointed "in order that the ministry of the word and prayer might be carried on more faithfully." What I hope is obvious is that I am not alone in seeing the importance of Acts 6:4 for defining the pastor's work today. Bede Frost said,

All depend upon this: to pray and to teach souls to pray-it is all. For given this, everything else will follow. It is as true to-day as ever. No duty is more incumbent upon the clergy than this. Unless they themselves learn how to pray,

${ }^{1}$ Ibid., vii.

${ }^{2}$ Lawrence O. Richards and Gilbert R. Martin, Lay Ministry: Empowering the People of God (Grand Rapids: Ministry Resources Library, 1988), 179.

${ }^{3}$ Robert J. Karris, Invitation to Acts: A Commentary on the Acts of the Apostles with Complete Text from the Jerusalem Bible (Garden City, NY: Image Books, 1978), 77.

${ }^{4}$ Philip Van Linden, The Gospel of Luke and Acts, Message of Biblical Spirituality Series, 10 (Wilmington, DE: Michael Glazier, 1986), 57. 
and centre all their efforts on teaching others to pray, their work is useless. ${ }^{5}$

Some may consider Frost's assertion an overstatement, but I hope it is not considered an overstatement for me to say that prayer should be fundamental to who I am as a pastor.

There is a reason for this, one I have touched on before. It is only as I pray-only as I spend time in communion with God-that I am going to be truly effective in my ministry. $M y$ best preaching, my best waiting on tables, will make no impact for His kingdom without His blessing. This is because, as Jon Paulien says, "You cannot help a secular person to find God if you do not know Him for yourself."2 Paulien reaffirms that our "ministry must begin in the devotional room."3

\section{Jesus: Between the Mountain and the Multitude}

Do we need to be reminded of the request of Jesus' disciples, "Lord, teach us to pray" (Luke 11:1)? As has been pointed out by many others, their profound request was not, "Teach us how to pray," but rather simply, "Teach us to pray." It was these same disciples who later devote themselves to this same priority: prayer. The assignment for today's pastors is still the same: learn to pray. The example of Jesus teaches ministers to pray. The pattern set by His apostles also teaches us to pray. And we have found in the practice of their successors to ministry, the elders, a

\footnotetext{
${ }^{1}$ Frost, 7-8.
}

${ }^{2}$ Jon Paulien, Present Truth in the Real World: The Adventist Struggle to Keep and Share Faith in a Secular Society (Boise, ID: Pacific Press Publishing Association, 1993), 89. This, of course, is true for all effective ministry regardless of whether for secular or unsecular people.

${ }^{3}$ Ibid., 90. 
repetition of this same lesson: pray. This same Jesus is as willing to teach us to pray as He was His disciples.

Jesus is sometimes described as having spent His ministry between the mountain and the multitude. In the first chapter of his gospel, Mark gives us a series of pictures from a single day in the life of Jesus. The story of that Sabbath in Capernaum is found in Mark 1:21-39. On the day Jesus made for rest, we find Him busy teaching and healing. His work, however, is complemented by prayer. Mark tells us, "Very early in the morning, while it was still dark, Jesus got up, left the house and went off to a solitary place, where he prayed" (vs. 35). The Gospel of Mark is generally recognized as the earliest attempt to provide the story of Jesus in written form. And this is the earliest reference to prayer in Mark's story of Jesus' life. Here is the beginning of the pattern in Jesus' ministry where each day His work was balanced by His retreat to the sanctuary of the mountains for communion with His Father.

Here in this one day in Jesus' ministry we see a rhythm between mountain and multitude that I believe must be the pattern for my ministry.

The life must be like Christ's life-between the mountain and the multitude. He who does nothing but pray will soon cease to pray, or his prayers will become a formal routine. When men take themselves out of social life, away from the sphere of Christian duty and cross bearing; when they cease to work earnestly for the Master, who worked earnestly for them, they lose the subject matter of prayer and have no incentive to devotion. Their prayers become personal and selfish. They cannot pray in regard to the wants of humanity or the upbuilding of Christ's kingdom, pleading for strength wherewith to work. ${ }^{1}$

${ }^{1}$ Ellen G. White, Steps to Christ (Mountain View, CA: Pacific Press Publishing Association, 1956), 101. 


\section{Epaphras: His Work Was Prayer}

The third biblical model of ministry which I want to suggest for consideration is that of Epaphras. An associate of Paul, he was the probable founder of the church in Colossae. In writing to that church from his imprisonment in Rome, the Apostle refers to Epaphras as "our dear fellow servant, who is a faithful minister of Christ" (Col 1:7). At the letter's close, Paul says Epaphras "is always wrestling in prayer for you, that you may stand firm in the will of God, mature and fully assured. . . He is working hard (italics mine) for you" (Col 4:12-13). Ben Patterson says, "Epaphras' hard work for the church was his earnest prayers on their behalf!"

D. Edmond Hiebert's comment, "The example of Epaphras is a challenge to Christians today to engage in this important ministry,"2 is especially pertinent to those of us who are engaged as ministers. According to Charles R. Erdman, "The particular service which Epaphras now is rendering ... is the service of intercessory prayer." ${ }^{3}$ This is the role in which I believe John the Elder pictures the twenty-four heavenly elders whom he saw "holding golden bowls full of incense, which are the prayers of the saints" (Rev 5:8). As intercessors "we stand with the hosts of heaven at the throne of grace, and this great assembly of adoration makes a difference in how God acts upon the world." A pastor's unremitting intercession for his members

${ }^{1}$ Patterson, "The Central Work of Prayer," 117.

${ }^{2}$ D. Edmond Hiebert, "Epaphras, Man of Prayer," Bibliotheca Sacra 136, no. 541 (JanuaryMarch 1979): 59.

${ }^{3}$ Charles R. Erdman, The Epistles of Paul to the Colossians and to Philemon (Philadelphia: Westminster Press, 1933), 107.

${ }^{4}$ Koenig, 165. 
and the advance of Christ's kingdom is a form of Christian work demanded in every age. Writing of Epaphras, W. H. Griffith Thomas says,

Often intercession is the most necessary and also the most blessed work we can do. Whether our prayers are for individuals or for whole communities of Christians, we ought, as priests "unto our God" (Rev. 5:10), to make the fullest possible use of this ministry of intercession. If anyone should think that this is difficult, the apostle, as we have seen, testifies that the prayer-life of Epaphras did indeed involve "much labor" (v. 13, A.S.V.) for his converts. Of him the old Latin motto was true- "to pray is to labor"-with its corollary, "to labor is to pray."1

Epaphras predates Benedict of Nursia in his famous approach to prayer and work by five centuries. E. K. Simpson and F. F. Bruce write, "Praying is working; and by such fervent prayer Epaphras toiled effectively on behalf of the churches of Colossae and Laodicea and Hierapolis." ${ }^{2}$ Epaphras expressed his pastoral care in the depth of his prayers. "He did not merely pray in vague generalities. He focused sharply on their real spiritual needs."3

Paul "never showed such esteem for a fellow-worker as he does here for Epaphras." ${ }^{4}$ According to N. T. Wright "Paul regards prayer as more than just a pious ancillary activity to preaching and teaching: it is part of the work itself."

${ }^{1}$ W. H. Griffith Thomas, Studies in Colossians and Philemon, ed. by his daughter (Grand Rapids: Baker Book House, 1973), 138-139.

${ }^{2}$ E. K. Simpson and F. F. Bruce, Commentary on the Epistles to the Ephesians and the Colossians: The English Text with Introduction, Exposition and Notes (Grand Rapids: Wm. B. Eerdmans Publishing, 1957), 307.

${ }^{3}$ W. D. Thomas, "New Testament Characters, V. Epaphras." The Expository Times 95, no. 7 (April 1984): 218.

${ }^{4} \mathrm{~W}$. Marxsen, Introduction to the New Testament: An Approach to Its Problems, trans. from the 3d German ed. (1964) by G. Buswell (Philadelphia: Fortress Press, 1968), 178.

${ }^{5}$ N. T. Wright, The Epistles of Paul to the Colossians and to Philemon: An Introduction and Commentary (Leicester, England: Inter-Varsity Press, 1986; Grand Rapids: William B. Eerdmans Publishing Company, 1986), 158. 
Prayer is to be part of my work as a pastor. This point is made once more by

Eugene Bradford who writes,

The example of Epaphras, a minister of Christ, but not an apostle, gives warrant to the judgment that the devotion of the apostles to prayer and to the ministry of the Word carries over to the perpetual office of the minister and is not to be considered tied to the extraordinary apostolic office. ... It is clearly a part of the minister's task to give himself to prayer for his flock. ${ }^{1}$

\section{Let Us Pray}

There is one more thing that is necessary in addition to teaching pastors to pray-it is giving them permission to pray. The interpretation is mine, but these words belong to James: "Let them pray." The setting for the apostle's directive is the need of an individual church member who is sick. James says, "Call for the elders of the church, and let them pray" (Jas 5:14 NASB). "Sick" is how many describe today's church. Would it not be appropriate then to "call for the elders of the church, and let them pray"? Today's elders are the churches' pastors. Call the pastors of the churches, and let them pray. Give us permission to "give our attention to prayer and the ministry of the word."

This story is about one pastor whose church gave him permission to pray:

In desperation I went to my church Session and resigned. . . . I told them that I had no time for close personal relationships and no time for prayer. Not only was there no time, but my very capacity for love and prayer had atrophied alarmingly. I told them that I had been trying to change but could not, and I could see no way out but to get out of there and get a new start someplace else. I said, "Take me up and throw me into the sea."

They did it, but not in the way I asked. Instead they put a question to me: "What do you want to do?" I had an answer for that, but I didn't know how to do it. My answer was that I wanted to deal with God and people. I told them, "I want to study God's word long and carefully so that when I stand before you

${ }^{1}$ Bradford, 27-28. 
and preach and teach I will be accurate. I want to pray, slowly and lovingly, so that my relation with God will be inward and honest. And I want to be with you, often and leisurely, so that we can recognize each other as close companions on the way of the cross and be available for counsel and encouragement to each other." These were what I had started out intending when I became a pastor, but working in and for the church had pushed them to the fringes.

One elder said, with some astonishment, "If that is what you want to do, why don't you do it? Nobody told you you couldn't, did they?" And I, with a touch of anger, said, "Because I have to run this church. Do you realize that running this church is a full-time job? There is simply no time to be a pastor."

Another elder said. "Why don't you let us run the church?" I said, "You don't know how." He said, "It sounds to me like you don't know how to be a pastor either. How about you let us learn how to run the church and we let you learn how to be a pastor?"

It was one of those wonderful moments in the life of the church when the heavens open and the dove descends. ${ }^{1}$

That was the story of Eugene H. Peterson, who has become the "guru" of ministry and spirituality for many pastors through his extensive writings on the subject. A dramatic experience like his is not all that is needed to establish pastoral priorities consistent with our call to "prayer and the ministry of the word." Peterson says he had only just begun. For him there was still the long process of learning to be a pastor. He continues his story by asking,

How do I embody this life of prayer and scripture and spiritual direction in this most uncongenial of settings-a denominational world that rarely mentions them and a congregational world that expects something more in the way of solace and a weekend of religious programs. ${ }^{2}$

The church-both denomination and congregation-truly can be an uncongenial setting in which to be a pastor called to prayer. Perhaps that is the impression that stands out above all others from my interviews with my five pastoral friends. All of them were surrounded by factors in their working environments

\footnotetext{
${ }^{1}$ Peterson, Under the Unpredictable Plant, 38-39.

${ }^{2}$ Ibid., 40.
} 
which made a life of prayer difficult. I would advise against dismissing their frustrations with the simple judgment that they are pastoral milquetoasts. To assume that they suffer from some weakness that could be overcome by trying harder would also be to misjudge them. Their stories call for more than individual assertiveness and intentionality in ministry.

\section{Three Things Are Needed}

If today's pastors are to accord prayer the priority it deserves as part of their work, they will need help in several areas. One thing which is needed is an understanding of how pervasive the pressures are that squeeze prayer from ministry. Denominational expectations of clergy will need to be modified to reflect the importance of prayer to ministry. I am reminded again of Biersdorf's caution. He says,

The tension or contradiction between the faith grounded in prayer mandated in our calling and the daily pressures of ministry that endanger that fundamental meaning and motivation is not simply a problem to be solved. To suggest a quick solution ... is to discount the experience of so many ministers who have personally wrestled with these issues. It is not accidental that we struggle with the contradiction; it is central to our ministry. ${ }^{1}$

Another thing which is needed is an appreciation of the civil war which rages within pastors. While the struggle between being and doing is not peculiar to them, it certainly is exaggerated by their calling to be persons of prayer. Eugene $\mathrm{H}$.

Peterson's confession to his church Session, "I told them that I had been trying to change but could not," is reminiscent of Paul's cry in Rom 7, where he says, "For what I want to do I do not do, but what I hate I do" (vs. 15). The Apostle bares his

\footnotetext{
${ }^{1}$ Biersdorf, $x$.
} 
soul when he confesses to

an experience which is of the very essence of the human situation. He knew what was right; he wanted to do what was right; and yet, somehow, he could never do it. He knew what was wrong; the last thing that he wanted to do was to do it; and yet, somehow, he did it. He felt himself to be a split personality. It was as if two men were inside the one skin. He felt himself pulled in two directions. He knew himself to be a walking civil war. ${ }^{1}$

Sometimes this is how it is with me and many of my pastor friends. A smaller version of the struggle between what is right and what is wrong is played out daily in our work as we live with the tension between being and doing. As pastors we must realize the implications of this civil war within each of us. Our natural tendencies are very much at odds with what we know is right and what we want to do. Our rescue from this war is found, as was Paul's, "through Jesus Christ our Lord!” (vs. 25) and not in trying harder.

A third thing which is needed is encouragement. As pastors we need more than to be held accountable; we need to be supported in our calling to prayer. It was Dan, one of the pastors I interviewed, who said, "I only wish that somebody would encourage me in my prayer and challenge me and affirm me that praying is an essential part of my work." Here is where our congregations should be called on to provide the needed encouragement for us, as pastors, to attend faithfully to our work of prayer on their behalf.

\section{A Final Word}

My personal feelings about the dilemma I face as a modern minister,

\footnotetext{
${ }^{1}$ William Barclay, The Letter to the Romans: Translated with an Introduction and Interpretation, 2d ed., Daily Study Bible Series (Philadelphia: Westminster Press, 1957), 100-101.
} 
stretched between my accountability to God and the expectations of my parishioners, is poignantly voiced in these few lines of Robert Frost's poem, "Birches":

It's when I'm weary of considerations, And life is too much like a pathless wood Where your face burns and tickles with the cobwebs Broken across it, and one eye is weeping From a twig's having lashed across it open. I'd like to get away from earth awhile And then come back to it and begin over. May no fate willfully misunderstand me And half grant what I wish and snatch me away Not to return. Earth's the right place for love:

I don't know where it's likely to go better. ${ }^{1}$

Admittedly the considerations of ministry were not those which wearied Frost when he pined, "I'd like to get away from earth awhile / And then come back to it and begin over." But don't we all dream of beginning anew? There are days when "a pathless wood" seems an apt description for my ministry. But before some "fate willfully misunderstand[s] me / And half grant[s] what I wish and snatch[es] me away / Not to return" I want to say that "I don't know where it's likely to go better."

Considerations aside, I have no doubt that ministry is the right place for me. And as I sort through the many daunting roles I am expected to fulfill as a pastor, I aim to keep my job simple. For me, Scripture describes two essential roles: "prayer and the ministry of the word" (Acts 6:4). This project has served to bring me back to this ministry which God in His mercy has given to me. With Eugene H. Peterson I return "to my parish rounds determined to set one foot after the other prayerfully."2 My prayer is:

\footnotetext{
${ }^{1}$ Robert Frost, "Birches," in Complete Poems of Robert Frost, paperback ed. (London: Jonathan Cape, 1967), 145-147.

${ }^{2}$ Peterson, Under the Unpredictable Plant, 67.
} 
"Lord Jesus, keep me faithful in my prayers for those you have given to me: for family and friends, for neighbors and colleagues. Let my work in prayer sustain them in their work of love. Amen."1

${ }^{1}$ Eugene H. Peterson, Praying with Jesus: A Year of Daily Pravers and Reflections on the Words and Actions of Jesus (New York: HarperCollins Publishers, 1993), Prayer for December 11. 


\section{APPENDIX A}

\section{INTERVIEW QUESTIONS}

Introduction: I want to understand from your perspective the place of prayer as a part of your work as a pastor.

1. Tell me the story of your personal prayer pilgrimage. How did you learn to pray? Who/what has influenced your prayer life?

2. Tell me about your present practice of prayer-both private and public. How/when/where/why/what do you pray?

3. Tell me how you understand prayer? How would you define prayer?

4. Tell me how prayer is part of your work as a pastor. Please share examples or experiences.

5. Tell me how you understand the relation of prayer to your work as a pastor. What do you think the relationship should be?

6. Tell me what keeps you as a pastor from your work of prayer? What do you believe are some reasons why prayer is not practiced as part of pastors' work?

7. Tell me what advice would you give to a new pastor regarding the priority of prayer in his/her work?

(These questions were used as a general outline for my interviews. I adapted them according to the particular situation.) 
APPENDIX B

CARTOONS 


\section{1}

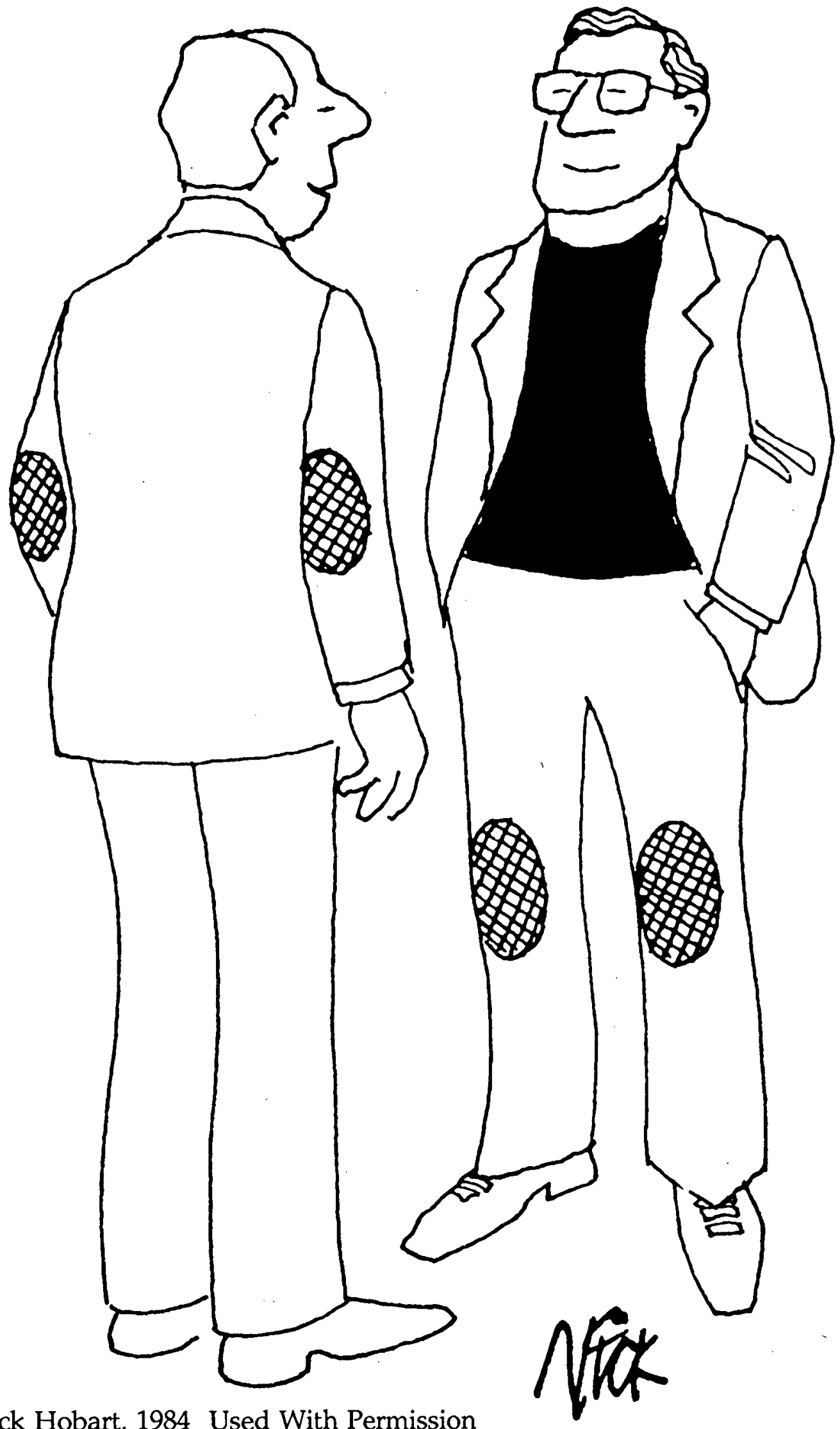

CNick Hobart, 1984 Used With Permission 


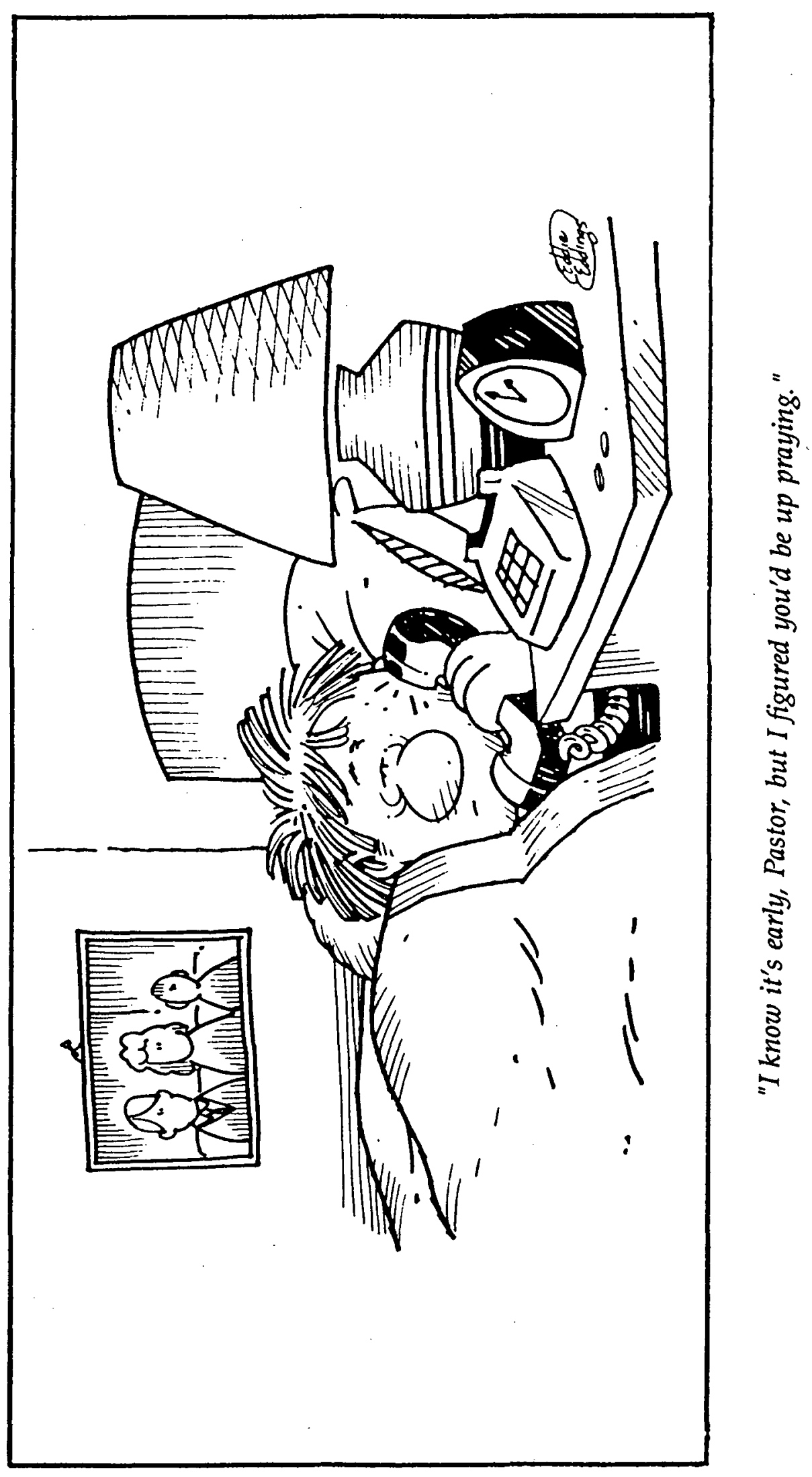

CEddie Eddings, 1988 Used With Permission 


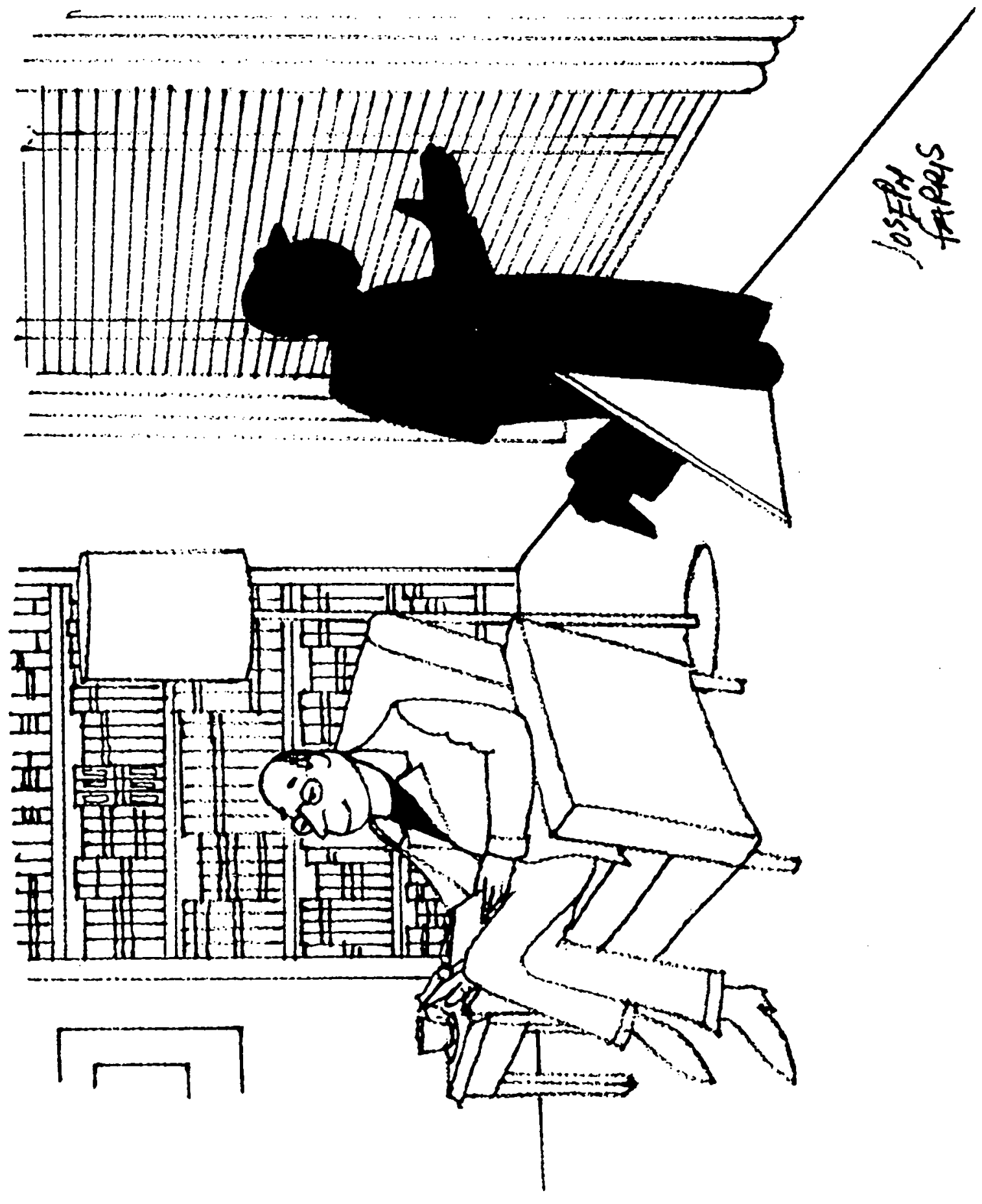

CLEADERSHIP, 1983. Artist, Joseph Farris. Concept, Judy Muck. Used With Permission 


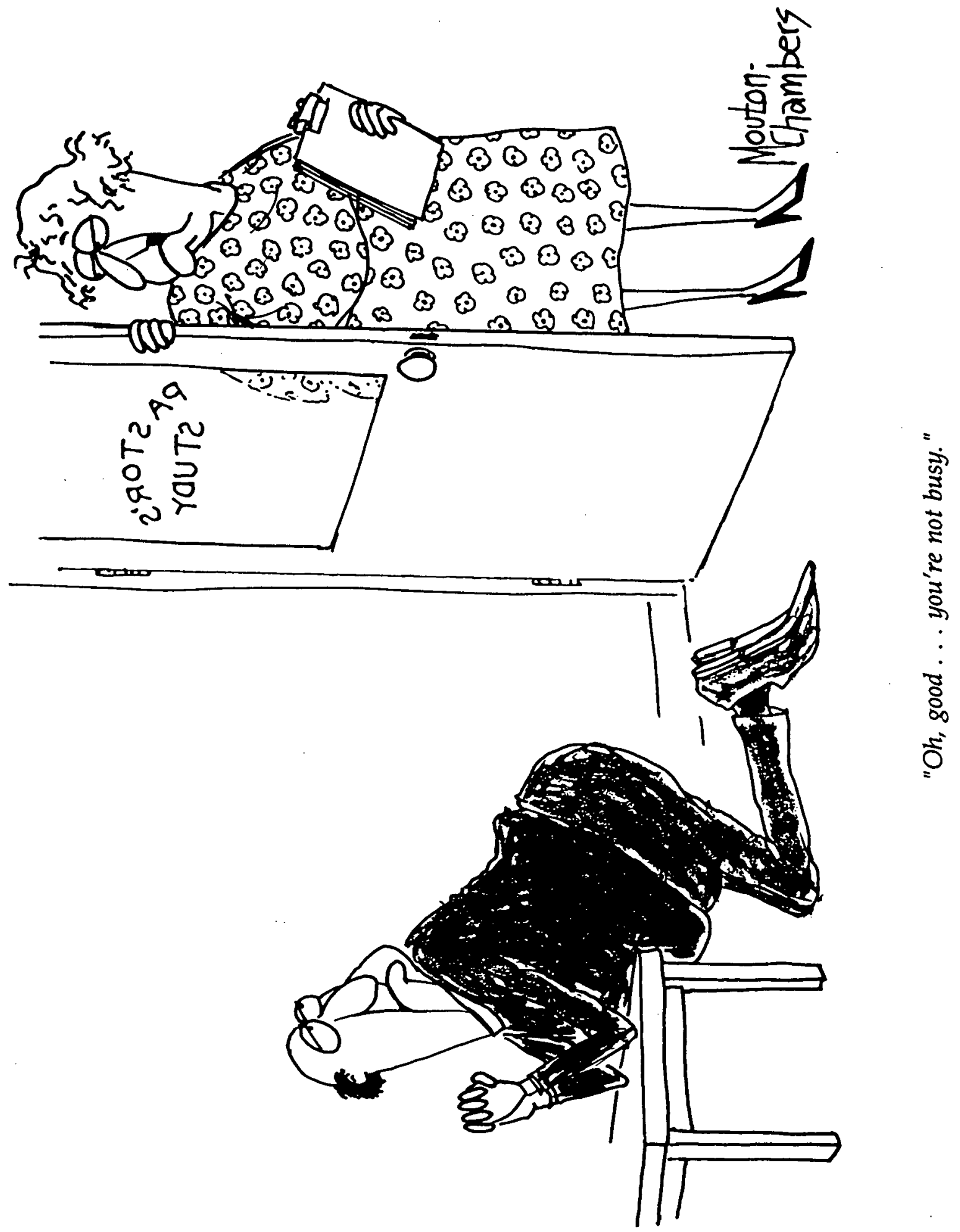

CMary Chambers, 1983 Used With Permission 


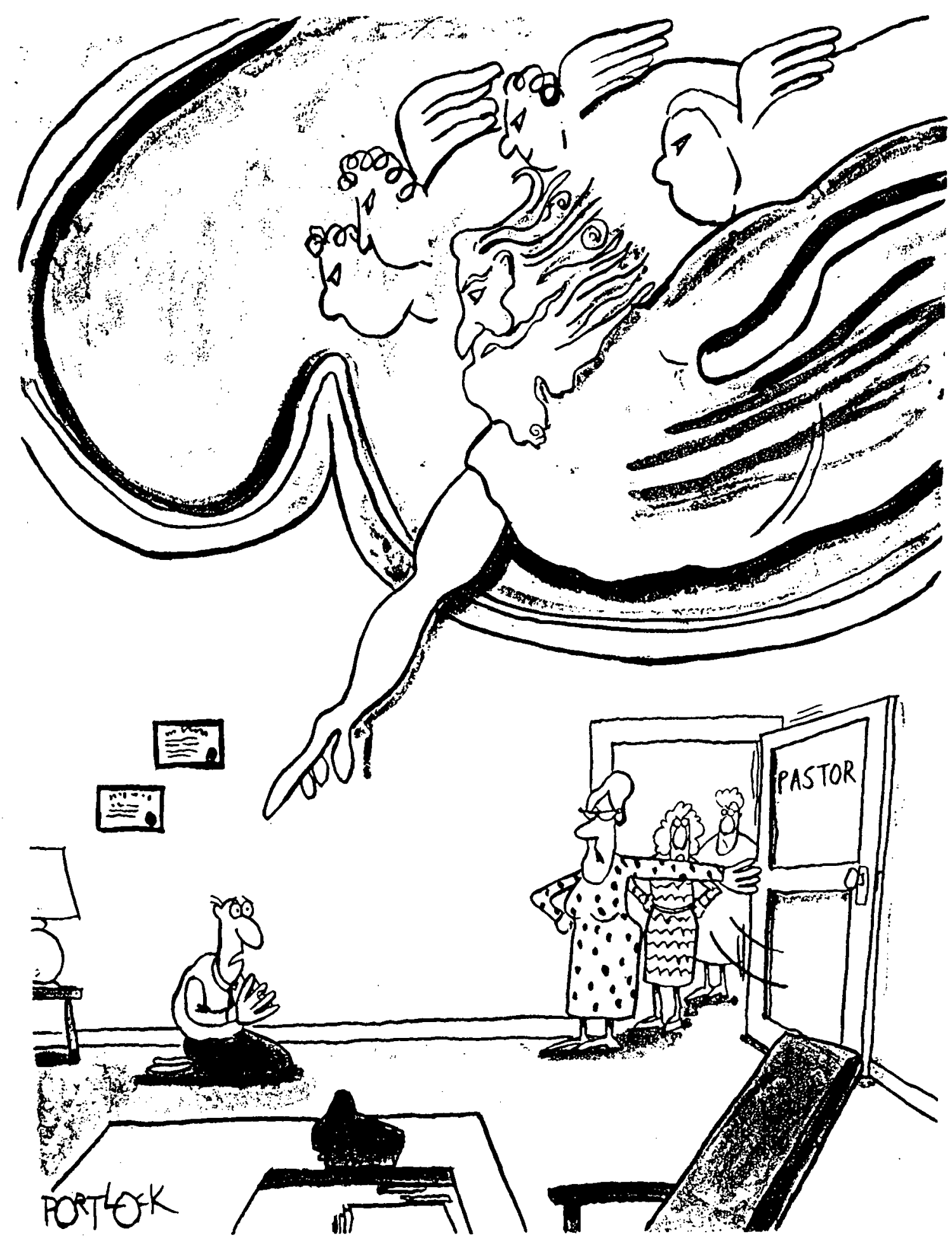

"We don't know what you're doing in here, but we've been waiting five minutes to talk to you about the broken hand dryer in the ladies room."

CRob Portlock, 1988 Used With Permission 


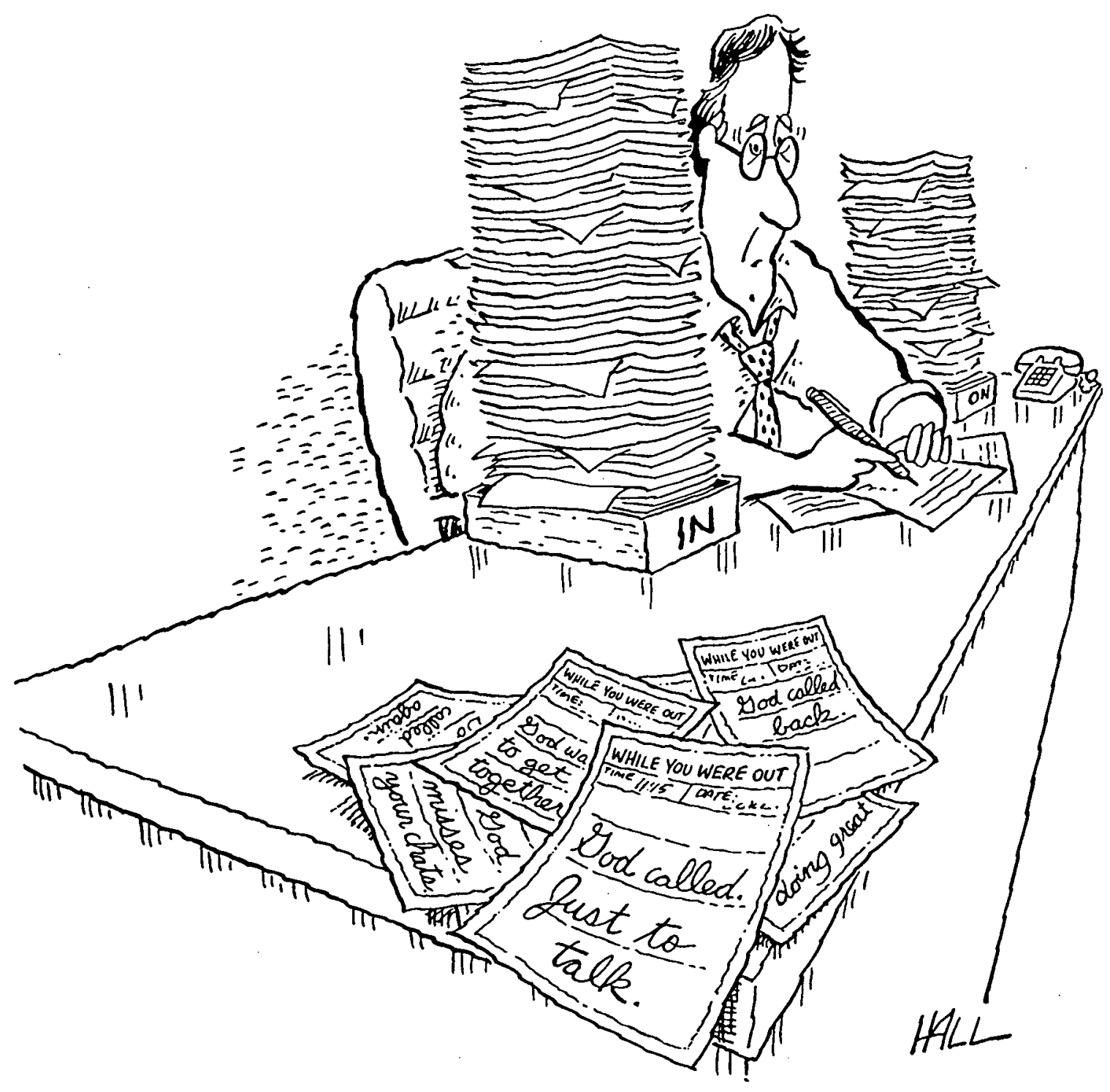

CDoug Hall, 1993 Used With Permission 


\section{SELECTED BIBLIOGRAPHY}

Alspaugh, John C. "The Caring Ministry: Concepts and Methods of Ministry to Inactive Members of the Stone Tower Seventh-day Adventist Church, Portland, Oregon." D.Min. project report, Andrews University, Seventh-day Adventist Theological Seminary, 1986.

Andrewartha, John Maxwell. "Elder, Bishop, Pastor: A Descriptive Study of the Terms and Their Implications for a Contemporary Ecclesiology." Ph.D. dissertation, Southwestern Baptist Theological Seminary, 1989.

Aoki, Ted T. Toward Curriculum Inquiry in a New Key. Curriculum Praxis, no. 2. Edmonton, Alberta, Canada: Publication Services, 1988.

Arnall, Marie. "His Prayer." In Priest: Person and Ministry, ed. Gerard Meagher, 157-167. Dublin: Gill and MacMillan, 1970; London: MacMillan and Co., 1970.

Baptism, Eucharist and Ministry. Faith and Order Paper No. 111. Geneva: World Council of Churches, 1982.

Barclay, William. The Letter to the Romans: Translated with an Introduction and Interpretation. 2d ed. Daily Study Bible Series. Philadelphia: Westminster Press, 1957.

Barna, George. Today's Pastors: A Revealing Look at What Pastors Are Saying about Themselves. Their Peers and the Pressures They Face. Ventura, CA: Regal Books, 1993.

Barnett, James Monroe. The Diaconate: A Full and Equal Order. New York: Seabury Press, 1981.

Barth, Karl. Prayer and Preaching. Translated by Sara F. Terrien and revised by B. E. Hooke. London: SCM Press, 1964.

Bartlett, David L. Ministry in the New Testament. Minneapolis: Fortress Press, 1993. 
Bassett, W. Philip. "Classroom Implementation of Cooperative Learning: Qualitative Case Studies of Three Early Elementary Teachers." Ph.D. dissertation Andrews University, School of Education, 1991.

Berg, Bruce L. Qualitative Research for the Social Sciences. Boston: Allyn and Bacon, 1989.

Biersdorf, John E. How Prayer Shapes Ministry. Washington, DC: Alban Institute, 1992.

Black, Donald Raymond. "Intercessory Prayer in Pastoral Care." D.Min. thesis, Princeton Theological Seminary, 1982.

Blackwood, Andrew Watterson. Doctrinal Preaching for Today: Case Studies of Bible Teachings. New York: Abingdon Press, 1956.

Blizzard, Samuel W. "The Minister's Dilemma." The Christian Century, 25 April 1956, 508-510.

The Book of Common Prayer. New York: Oxford University Press, 1952.

Boers, Arthur P. "The Pastor's Life of Prayer." The Christian Ministry 25, no. 2 (March-April 1994):10-13.

Boisen, Anton T. "The Period of Beginnings." The Journal of Pastoral Care 5, no. 1 (Spring 1951): 13-16.

Bradford, Eugene. "Intercessory Prayer: A Ministerial Task." The Westminster Theological Journal 22, no. 1 (November 1959): 13-48.

Bridge, J. David. “The Pastor's Problems: VIII. The Pastor's Priorities.” The Expository Times 93, no. 2 (November 1981): 36-39.

Brown, Raymond E. "Episkopē and Episkopos: The New Testament Evidence." Theological Studies 41, no. 2 (June 1980): 322-338.

- Priest and Bishop: Biblical Reflections. New York: Paulist Press, 1970.

Bruce, F. F. The Acts of the Apostles: The Greek Text with Introduction and Commentary. 3d ed. Grand Rapids: Wm. B. Eerdmans Publishing Company; Leicester, England: Apollos, 1990.

Campbell, James M. The Place of Prayer in the Christian Religion. New York: Methodist Book Concern, 1915. 
Carey, George. "The Origins of the Threefold Christian Ministry." Churchman 96, no. 1 (1982): 36-43.

Clapp, Rodney. "How Many Hats Does Your Pastor Wear?" Christianity Today, 3 February 1984, 24-27.

Coleman, Robert E. "The Prayer Life of the Christian Minister." In A Celebration of Ministry: Essays in Honor of Frank Bateman Stanger, ed. Kenneth Cain Kinghorn, 80-87. Wilmore, KY: Francis Asbury Publishing Company, 1982.

Collins, John N. Diakonia: Re-interpreting the Ancient Sources. New York: Oxford University Press, 1990.

Cooke, Bernard. Ministry to Word and Sacraments: History and Theology. Philadelphia: Fortress Press, 1976.

Davie, Peter. Pastoral Care and the Parish. Oxford: Basil Blackwell Publisher, 1983.

Denys, Abbot, of Nashdom. Preface to The Art of Mental Prayer by Bede Frost. London: S.P.C.K., 1960.

Didier, George J., III. "Vocational Crisis and Transformation: From Ordained Clerical Priesthood to Lay Ministry." In Creative Ministries in Contemporary Christianity, ed. Perry LeFevre and W. Widick Schroeder, 205-223. Studies in Ministry and Parish Life. Chicago: Exploration Press, 1991.

Eisner, Elliot W. The Enlightened Eye: Oualitative Inquiry and the Enhancement of Educational Practice. New York: Macmillan Publishing Company; Toronto: Collier Macmillan Canada, 1991.

Erdman, Charles R. The Epistles of Paul to the Colossians and to Philemon. Philadelphia: Westminster Press, 1933.

Evans, Christopher. "Rediscovering Grace in an Impossible Calling." The Christian Ministry, 25, no. 1 (January-February 1994): 14-17.

Fitzmyer, Joseph A. The Gospel According to Luke (I-IX): Introduction, Translation. and Notes, 2d ed. Anchor Bible. Vol. 28. New York: Doubleday, 1981.

Forestell, J. T. As Ministers of Christ: The Christological Dimension of Ministry in the New Testament: An Exegetical and Theological Study. New York: Paulist Press, 1991.

Forsyth, P. T. The Church and the Sacraments. London: Independent Press, 1917. 
Positive Preaching and Modern Mind. London: Hodder and Stoughton, 1907.

Fowler, John W. Adventist Pastoral Ministry. Boise, ID: Pacific Press Publishing Association, 1990.

Frerichs, Wendell W. “The Pastor's Prayer Life." Dialog 32, no. 1 (Winter 1993): 29-32.

Frost, Bede. The Art of Mental Prayer. With a Preface by Abbot Denys of Nashdom. London: S.P.C.K., 1960.

Frost, Robert. "Birches." In Complete Poems of Robert Frost. Paperback ed. London: Jonathan Cape, 1967.

Fulfilled in Your Hearing: The Homily in the Sunday Assembly. Washington, DC: United States Catholic Conference, 1982.

Gaebelein, A. C. The Acts of the Apostles: An Exposition. New York: Publication Office "Our Hope," 1912.

Gerkin, Charles V. The Living Human Document: Re-Visioning Pastoral Counseling in a Hermeneutical Mode. Nashville: Abingdon Press, 1984.

Giles, Kevin. Patterns of Ministry Among the First Christians. Melbourne: Collins Dove, 1989.

Glaser, Barney G., and Anselm L. Strauss. The Discovery of Grounded Theory: Strategies for Qualitative Research. Chicago: Adline, 1967.

Glasscock, Ed. "The Biblical Concept of Elder." Bibliotheca Sacra 144, no. 573 (January-March 1987): 66-78.

Glasse, James D. Profession: Minister. Nashville: Abingdon Press, 1968.

Goetsch, Ronald W. "The Pastor's Devotional Prayer Life." Concordia Journal 12, no. 6 (November 1986): 217-220.

Goetz, David L. "How Pastors Practice the Presence." Leadership 14, no. 4 (Fall 1993): 28-35.

Goodykoontz, Harry G. The Minister in the Reformed Tradition. Richmond, VA: John Knox Press, 1963.

Green, Michael. Called to Serve: Ministry and Minsters in the Church. Philadelphia: Westminster Press, 1964. 
Greshake, Gisbert. The Meaning of Christian Priesthood. With a Foreword by Desmond Connell. Translated by Peadar MacSeumais. Dublin: Four Courts Press, 1988.

Gulbranson, Gary L. "Using Our Spiritual Resources." In Mastering Pastoral Counseling, ed. Archibald Hart, Gary Gulbranson, and James Smith, 15-24. Portland, OR: Multnomah Press, 1992.

Gutzke, Manford George. Plain Talk on Acts. Grand Rapids: Zondervan Publishing House, 1966.

Haenchen, Ernst. The Acts of the Apostles. Translated from the 14th German ed. (1965) by Bernard Noble and Gerald Shinn. Translation updated and revised by R. McL. Wilson. Philadelphia: Westminster Press, 1971.

Halvorson, Loren E. "Prayer and Action," In A Primer on Prayer, ed. Paul R. Sponheim, 91-104. Philadelphia: Fortress Press, 1988.

Hands, Donald R., and Wayne L. Fehr. Spiritual Wholeness for Clergy: A New Psychology of Intimacy with God, Self and Others. With a Foreword by Susan Howatch. Washington, DC: Alban Institute, 1993.

Hansen, David. "Upon Taking a Small Church." Leadership 11, no. 2 (Spring 1990): 78-79.

Harrison, Everett F. Acts: The Expanding Church. Chicago: Moody Press, 1975.

Harvey, A. E. "Elders." The Journal of Theological Studies, n.s., 25, part 2 (October 1974): 318-332.

Havel, Vaclav. Speech given to the World Economics Forum in Davos, Switzerland, 1992.

Hayden, Daniel R. "Calling the Elders to Pray." Bibliotheca Sacra 138, no. 551 (July-September 1981): 258-266.

Herzog, William R., II. "The Origins of Ministry in the New Testament." American Baptist Quarterly 3, no. 2 (June 1984): 117-148.

Hiebert, D. Edmond. "Counsel for Christ's Under-Shepherds: An Exposition of 1 Peter 5:1-4." Bibliotheca Sacra 139, no. 556 (October-December 1982): 330-341.

. "Epaphras, Man of Prayer." Bibliotheca Sacra 136, no. 541 (JanuaryMarch 1979): 54-64. 
The Epistle of James: Tests of a Living Faith. Chicago: Moody Press, 1979.

“An Exposition of 3 John 1-4.” Bibliotheca Sacra 144, no. 573 (JanuaryMarch 1987): 53-65.

. First Peter. Chicago: Moody Press, 1984.

Hoekstra, Charles E. "An Examination of the Prayer Life of Jesus to Ascertain the Relation of Prayer to the Pastor's Work." D.Min. dissertation, Covenant Theological Seminary, 1987.

Holmes, Urban T., III. Spirituality for Ministry. San Francisco: Harper \& Row, Publishers, 1982.

Hurtado, L. W. "Revelation 4-5 in the Light of Jewish Apocalyptic Analogies." Journal for the Study of the New Testament 25 (October 1985): 105-124.

Jarrow, The Bishop of [A. K. Hamilton]. "The Priest as a Man of Prayer and a Teacher of Prayer." Theology 71, no. 571 (January 1968): 7-12.

Johnson, Ben Campbell. Pastoral Spirituality: A Focus for Ministry. Philadelphia: Westminster Press, 1988.

Johnson, Luke T. Decision Making in the Church: A Biblical Model. Philadelphia: Fortress Press, 1983.

Karris, Robert J. Invitation to Acts: A Commentary on the Acts of the Apostles with Complete Text from the Jerusalem Bible. Garden City, NY: Image Books, 1978.

Kelley, Joseph F. The Concise Dictionary of Early Christianity. Collegeville, MN: Liturgical Press, 1992.

Killian, Charles. "Spiritual Disciplines for the Undisciplined." Interview by Bob Moeller. Leadership 14, no. 4 (Fall 1993): 48-53.

Kistemaker, Simon J. The New Testament Commentary: Exposition of the Acts of the Apostles. Grand Rapids: Baker Book House, 1990.

- New Testament Commentary: Exposition of the Epistles of Peter and of the Epistle of Jude. Grand Rapids: Baker Book House, 1987. 
Knight, George W., III. "Two Offices (Elders/Bishops and Deacons) and Two Orders of Elders (Preaching/Teaching Elders and Ruling Elders): A New Testament Study." Presbyterion: Covenant Seminary Review 11, no. 1 (Spring 1985): 1-12.

Koenig, John. Rediscovering New Testament Prayer: Boldness and Blessing in the Name of Jesus. San Francisco: Harper, 1992.

Lenski, R. C. H. Interpretations of the Acts of the Apostles. Columbus, OH: Wartburg Press, 1944.

Lienhard, Joseph T. "Acts 6:1-6: A Redactional View." The Catholic Biblical Quarterly 37, no. 2 (April 1975): 228-236.

Lieu, Judith. The Second and Third Epistles of John: History and Background, ed. John Riches. Edinburgh: T. and T. Clark, 1986.

. The Theology of the Johannine Epistles. New Testament Theology. Cambridge: Cambridge University Press, 1991.

Lischer, Richard. "Other Voices in Homiletics." Homiletic 16, no. 1 (Summer 1991): 1-4.

Lövestam, Evald. "Paul's Address at Miletus." Studia Theologica 41, no. 1 (1987): $1-10$.

Lutzer, Erwin W. “The Priorities of the Preacher." Moody Monthly 87, no. 1 (September 1986): 33-35.

Marxsen, W. Introduction to the New Testament: An Approach to Its Problems. Translated from the 3d German ed. (1964) by G. Buswell. Philadelphia: Fortress Press, 1968.

McCutcheon, James N. The Pastoral Ministry. Nashville: Abingdon, 1978.

McFarland, John Robert. "Neglecting Parish Pastors." The Christian Ministry 21, no. 2 (March-April 1990): 10-11.

McLaughlin, Eleanor L. "Priestly Spirituality." Anglican Theological Review 66, Supplementary Series, no. 9 (1984): 52-69.

Meagher, Gerard. Introduction to Priest: Person and Ministry. Edited by Gerard Meagher. Dublin: Gill and MacMillan, 1970.

Messer, Donald E. Contemporary Images of Christian Ministry. Nashville: Abingdon Press, 1989. 
Michaels, J. Ramsey. 1 Peter. Word Biblical Commentary. Vol. 49. Waco, TX: Word Books, Publisher, 1988.

Mickle, Jeffrey P. “Toward a Revised Diaconate.” Quarterly Review 2, no. 1 (Spring 1982): 43-61.

Middleton, Robert G. "Let the Minister Be a Minister." Foundations 2, no. 3 (July 1959): 198-206.

Privilege and Burden. Valley Forge, PA: Judson Press, 1969.

Miller-McLemore, Bonnie J., and William R. Myers. "The Doctorate of Ministry as an Exercise in Practical Theology: Qualitative Research with Living Human Documents." Journal of Supervision and Training in Ministry 11 (1989): 5-24.

Moellering, H. Armin. "Some New Testament Aspects of the Ministry Identified and Applied." Concordia Journal 14, no. 3 (July 1988): 229-247.

Morris, Derek J. "The Minister as a Spiritual Leader." In The Adventist Minister, ed. C. Raymond Holmes and Douglas R. Kilcher, 17-26. Berrien Springs, MI: Andrews University Press, 1991.

Morton, Russell Scott. “A History of Religions Analysis of Revelation 4-5." Th.D. dissertation, Lutheran School of Theology, 1985.

Mosser, David N. "Managing the Public Life, Freeing the Personal Life." The Christian Ministry 23, no. 2 (March-April 1992): 10-13.

Muck, Terry. Liberating the Leader's Prayer Life. Vol. 2, The Leadership Library. Carol Stream, IL: Christianity Today, 1985; Waco, TX: Word Books, 1985.

Munck, Johannes. The Acts of the Apostles: Introduction. Translation and Notes. Revised by William F. Albright and C. S. Mann. The Anchor Bible. Vol. 31. Garden City, NY: Doubleday \& Company, 1967.

Murphy, Humphrey Joseph. "A Qualitative Study of Work Satisfaction Among Archdiocesan Associate Pastors in Team and Traditional Style Urban Parochial Ministries." D.Min. project report, Boston University School of Theology, 1981.

Murray, Andrew. The Praver-Life: The Inner Chamber and the Deepest Secret of Pentecost. Chicago: Moody Press, n.d.

Navone, John J. Themes of St. Luke. Rome: Gregorian University Press, 1970. 
Neuhaus, Richard John. Freedom for Ministry, rev. ed. Grand Rapids: William B. Eerdmans Publishing Company, 1992.

Niebuhr, H. Richard. The Purpose of the Church and Its Ministry. New York: Harper \& Bros., 1956.

Niklas, Gerald R. The Making of a Pastoral Person. New York: Alba House, 1981.

Norris, Richard A., Jr. "The Beginnings of Christian Priesthood." Anglican Theological Review 66, Supplementary Series, no. 9 (1984): 18-32.

Nouwen, Henri J. M. The Living Reminder: Service and Prayer in Memory of Jesus Christ. New York: Seabury Press, 1977.

O'Brien, P. T. "Prayer in Luke-Acts.” Tyndale Bulletin 24 (1973): 111-127.

Osborn, Ronald E. "The Ordination of the Presbyter." Study Encounter 6, no. 4 (1970): 193-201.

Parker, Percy G. An Acceptable Minister of Christ. Philadelphia: Sunday School Times Company, 1924.

Patterson, Ben. "The Central Work of Prayer." Leadership 3, no. 1 (Winter 1982): 114-117.

. "Interview: Ben Patterson." Interview by R. Albert Mohler, Jr. Preaching 6, no. 3 (November-December 1990): 29-31.

Paul, Robert S. Ministry. Grand Rapids: William B. Eerdmans Publishing Company, 1965.

Paulien, Jon. Present Truth in the Real World: The Adventist Struggle to Keep and Share Faith in a Secular Society. Boise, ID: Pacific Press Publishing Association, 1993.

Pavey, Norman C. "Praying for Your People." The Christian Ministry 24, no. 2 (March-April 1993): 21-22.

Peterson, Eugene H. Five Smooth Stones for Pastoral Work. Atlanta: John Knox Press, 1980.

. “Mastering Ceremonies.” Leadership 8, no. 2 (Spring 1987): 88-91.

- Praying with Jesus: A Year of Daily Prayers and Reflections on the Words and Actions of Jesus. New York: HarperCollins Publishers, 1993. 
. "Return to the Timeless." Leadership 14, no. 2 (Spring 1993): 22-23.

. Under the Unpredictable Plant: An Exploration in Vocational Holiness.

Grand Rapids: William B. Eerdmans Publishing Company, 1992; Leominster, England: Gracewing, 1992.

Working the Angles: The Shape of Pastoral Integrity. Grand Rapids:

William B. Eerdmans Publishing Company, 1987.

Plymale, Steven Frederick. "The Prayer Texts of Luke-Acts." Ph.D. dissertation, Northwestern University, 1986.

Powers, B. W. "Patterns of New Testament Ministry-1. Elders." The Churchman 87, no. 3 (Autumn 1973): 166-181.

Quinn, Jerome D. "Apostolic Ministry and Apostolic Prayer." The Catholic Biblical Ouarterly 33 (1971), 479-491.

Ramsey, Michael. The Christian Priest Today. New York: Morehouse-Barlow, 1972.

Richards, Lawrence O., and Gilbert R. Martin. Lay Ministry: Empowering the People of God. Grand Rapids: Ministry Resources Library, 1988.

Rodenmayer, Robert N. We Have This Ministry. New York: Harper \& Bros., 1959.

Root, Michael. "Called to the Office of Ministry: The New Testament and Today." Currents in Theology and Mission 12, no. 2 (April 1985): 157-166.

Ross, Alexander. The Epistles of James and John. Grand Rapids: Wm. B. Eerdmans Publishing Company, 1954.

Sanders, J. Oswald. Spiritual Leadership. Chicago: Moody Press, 1967.

Schillebeeckx, Edward. Ministry: Leadership in the Community of Jesus Christ. Translated by John Bowden. New York: Crossroad, 1981.

Schobert, Wm. H. Letter to the Editor. The Christian Century, 16 May 1956, 621.

Schweizer, Eduard. Church Order in the New Testament. Studies in Biblical Theology, 32. Translated by Frank Clarke. Naperville, IL: Alec R. Allenson, 1961.

Seymour, Jack L. "Teaching as Religious Leadership: Rethinking the Pastoral Role." Quarterly Review 3, no. 3 (Fall 1983): 6-17. 
Simpson, E. K., and F. F. Bruce. Commentary on the Epistles to the Ephesians and the Colossians: The English Text with Introduction, Exposition and Notes. Grand Rapids: Wm. B. Eerdmans Publishing, 1957.

Sittler, Joseph. The Ecology of Faith. Philadelphia: Muhlenberg Press, 1961.

Sklba, Richard J. "Bishop, Prayer and Spirituality." Worship 57, no. 1 (January 1983): 61-72.

Smalley, Stephen S. 1,2,3 John. Word Biblical Commentary. Vol. 51. Waco, TX: Word Books, Publisher, 1984.

Smart, James D. The Rebirth of Ministry. Philadelphia: Westminster Press, 1960.

Smith, D. Moody. First, Second, and Third John. Interpretation: A Bible Commentary for Teaching and Preaching. Louisville: John Knox Press, 1991.

Smith, Donald P. Clergy in the Cross Fire: Coping with Role Conflict in the Ministry. Philadelphia: Westminster Press, 1973.

Sobosan, Jeffrey G. "The Role of the Presbyter: An Investigation into the Adversus Haereses of Saint Irenaeus." Scottish Journal of Theology 27, no. 2 (May 1974): 129-146.

Stanton, Timothy. "Prayer and Work, Mostly in South Africa." Review for Religious 52, no. 4 (July-August 1993): 553-565.

Stott, John R. W. "Ideals of Pastoral Ministry." Bibliotheca Sacra 146, no. 581 (January-March 1989): 3-11.

- The Letters of John: An Introduction and Commentary. Tyndale New Testament Commentaries. rev. ed. Leicester, England: Inter-Varsity Press, 1988; Grand Rapids: William B. Eerdmans Publishing Company, 1988.

Swears, Thomas R. The Approaching Sabbath: Spiritual Disciplines for Pastors. Nashville: Abingdon Press, 1991.

Thiering, B. E. "Mebaqqer and Episkopos in the Light of the Temple Scroll." Journal of Biblical Literature 100, no. 1 (March 1981): 59-74.

Thomas, W. D. "New Testament Characters, V. Epaphras." The Expository Times 95, no. 7 (April 1984): 217-218.

Thomas, W. H. Griffith. Studies in Colossians and Philemon. Edited by his daughter. Grand Rapids: Baker Book House, 1973. 
Thompson, James W. "Ministry in the New Testament." Restoration Ouarterly 27, no. 3 (1984): 143-156.

Throop, John R. "Practicing the Original Passion." Leadership 14, no. 4 (Fall 1993): 43-47.

Thurneysen, Eduard. A Theology of Pastoral Care. Translated by Jack A. Worthington and Thomas Wieser. Richmond, VA: John Knox Press, 1962.

Thurston, Bonnie. Spiritual Life in the Early Church: The Witness of Acts and Ephesians. Minneapolis: Fortress Press, 1993.

Tostengard, Sheldon A. "Preaching and the Pastoral Vocation." Word \& World 1, no. 4 (Fall 1981): 355-363.

Trites, Allison A. "The Prayer Motif in Luke-Acts." In Perspectives on Luke-Acts, ed. Charles H. Talbert, 168-186. Danville, VA: Association of Baptist Professors of Religion, 1978.

Tyson, Joseph B. "The Emerging Church and the Problem of Authority in Acts." Interpretation 42, no. 2 (April 1988): 132-145.

Underwood, Ralph L. Pastoral Care and the Means of Grace. Minneapolis: Fortress Press, 1993.

Van Linden, Philip. The Gospel of Luke and Acts. Message of Biblical Spirituality Series, 10. Wilmington, DE: Michael Glazier, 1986.

Van Voorst, Robert E. "Reforming Our Pastoral Ministry: An Essay on Role Conflict in the Ministerial Office." Reformed Review 46, no. 3 (Spring 1993): 189-203.

VanDenburgh, David Arnold. "The Effective Pastor: A Theology of Equipping Ministry for Seventh-day Adventist Pastors." D.Min. dissertation, Fuller Theological Seminary, 1992.

Vinet, A. Pastoral Theology; or. The Theory of the Evangelical Ministry. Translated and ed. Thomas H. Skinner. New York: Ivison, Phinney, Blakeman \& Co., 1866.

Vyhmeister, Werner K. Foreword to The Adventist Minister. Edited by C. Raymond Holmes and Douglas R. Kilcher. Berrien Springs, MI: Andrews University Press, 1991.

Watkins, Keith. "Ministers and Elders as Leaders of Worship in the Christian Church." Encounter 39, no. 3 (Summer 1978): 305-320. 
Westminster Assembly. Quoted in Eugene Bradford, "Intercessory Prayer: A Ministerial Task." The Westminster Theological Journal 22, no. 1 (November 1959): $13-48$.

Whiston, Charles F. The Lilly Endowment Project on the Deepening of the Spiritual Life of the Seminary Faculty. N.p.: Final Report, December 1970.

White, Ellen G. Evangelism. Washington, DC: Review and Herald Publishing Association, 1946.

. Gospel Workers. Washington, DC: Review and Herald Publishing Association, 1948.

- Steps to Christ. Mountain View, CA: Pacific Press Publishing Association, 1956.

Testimonies for the Church. 9 vols. Mountain View, CA: Pacific Press Publishing Association, 1948.

Willimon, William H. Acts. Interpretation: A Bible Commentary for Teaching and Preaching. Atlanta: John Knox Press, 1988.

Wills, Garry. "The '60s: Tornado of Wrath." Newsweek, 3 January 1994, 40.

Wilson-Kastner, Patricia. Imagery for Preaching. Minneapolis: Fortress Press, 1989.

Winger, Joseph M. "Hidden Efficiencies of Prayer." Leadership 14, no. 4 (Fall 1993): 46-47.

Wright, N. T. The Epistles of Paul to the Colossians and to Philemon: An Introduction and Commentary. Leicester, England: Inter-Varsity Press, 1986; Grand Rapids: William B. Eerdmans Publishing Company, 1986.

Young, Jerry R. “Shepherds, Lead!" Grace Theological Journal 6, no. 2 (1985): 329-335.

Ziegler, John J. "Who Can Anoint the Sick." Worship 61, no. 1 (January 1987): 25-44. 


\section{VITA}

The son of a Seventh-day Adventist pastor, Kenneth Lee Schander was born in Minneapolis, Minnesota, in 1948. He attended Newbold College and graduated from Columbia Union College in 1970 with a degree in history and economics. In 1975 he completed the Master of Divinity degree from the Seventh-day Adventist Theological Seminary. Since 1972 he has worked full-time as a Seventh-day Adventist pastor in Pennsylvania, Saskatchewan, Nova Scotia, and currently in Michigan.

Among other things he enjoys cycling, traveling, and gardening.

He and his wife, the former Frances Lowry, were married in June, 1972. They have a fifteen-year-old daughter, Heather.

Ken's passion is ministry: how to best do the task to which he feels God has called him. A growing feeling of his need for a prayer-ful ministry has spawned this interest in the pastor's prayer life. 